\title{
A família Asteraceae na Reserva Ecológica do Panga, Uberlândia, Minas Gerais, Brasil ${ }^{1}$
}

\author{
Eric Koiti Okiyama Hattori ${ }^{2,4}$ e Jimi Naoki Nakajima ${ }^{3}$
}

Recebido: 30.04.2009; aceito: 5.05.2011

\begin{abstract}
Asteraceae from Panga Ecological Reserve, Uberlandia, Minas Gerais, Brazil). A systematic treatment of the Asteraceae species is presented here. The ecological reserve, located $30 \mathrm{~km} \mathrm{~S}$ of the city of Uberlândia, has a mosaic of phytophysiognomies of the "Cerrado" domain. The specimens are from collections made since 1986 and are deposited at Herbarium Uberlandense (HUFU) of the Universidade Federal de Uberlandia, Minas Gerais. A total of 98 species distributed in 46 genera was recorded. The genera with the highest number of species are Vernonia (20 spp.), Chromolaena (10 spp.) and Baccharis (8 spp.). Identification key, followed by morphological descriptions of each species, information on distribution and comments on morphological similarities are presented.
\end{abstract}

Key words: Asteraceae, Minas Gerais, Panga Ecological Reserve, savanna

RESUMO - (A família Asteraceae na Reserva Ecológica do Panga, Uberlândia, Minas Gerais, Brasil). O tratamento sistemático das espécies de Asteraceae é apresentado aqui. A reserva ecológica está situada cerca de $30 \mathrm{~km}$ ao sul do centro do município de Uberlândia, MG, e possui um mosaico de fitofisionomias do domínio Cerrado. As exsicatas examinadas são de coletas realizadas desde o ano de 1986 e se encontram depositadas no Herbarium Uberlandense (HUFU) da Universidade Federal de Uberlândia, Minas Gerais. Asteraceae está representada por 98 espécies em 46 gêneros. Os gêneros mais bem representados são: Vernonia (20 spp.), Chromolaena (10 spp.) e Baccharis (oito spp.). Uma chave de identificação é apresentada para as espécies, seguida das descrições morfológicas, fitofisionomias que ocorrem e comentários sobre semelhanças morfológicas.

Palavras-chave: Asteraceae, cerrado, Minas Gerais, Reserva Ecológica do Panga

\section{Introdução}

A família Asteraceae compreende cerca de 24.000 espécies pertencentes a 1.600-1.700 gêneros, de distribuição ampla no planeta representando entre $8 \%$ e $12 \%$ do total de angiospermas (Funk et al. 2009). Cerca de metade das espécies de Asteraceae ocorre no Novo Mundo, especialmente nos Neotrópicos, sendo estimadas para a flora brasileira cerca de 2.000 espécies (Nakajima et al. 2010), distribuídas principalmente na vegetação árida, semi-árida e montanhosa, estando ausente ou pouco representada na floresta tropical úmida (Hind 1993).

Devido ao grande número de espécies da família, principalmente de alguns gêneros, como por exemplo,
Eupatorium L. e Vernonia Schreb., ainda são necessários maiores esforços, tanto de coleta de exemplares, quanto de revisões taxonômicas mais acuradas e atuais. Isto contribuirá para o maior conhecimento da flora, uma vez que inúmeras espécies ainda não foram descritas.

Particularmente para o Brasil, os estudos com a família iniciaram com o trabalho de Baker $(1873,1876$, $1882,1884)$. Posteriormente, foram feitos levantamentos de tribos ou gêneros para determinados estados ou localidades, ou ainda, os levantamentos florísticos da família como um todo, como por exemplo, Rio Grande do Sul (Malme 1932a), Mato Grosso (Malme 1932b, Dubs 1998), Paraná (Malme 1933),

1. Parte da dissertação de mestrado do primeiro autor

2. Universidade Federal de Uberlândia, Instituto de Biologia, Pós-Graduação em Ecologia e Conservação de Recursos Naturais

3. Universidade Federal de Uberlândia, Instituto de Biologia, Campus Umuarama, Bloco 2D, Uberlândia, MG

4. Autor para correspondência: erichattori@yahoo.com.br 
Itatiaia e cidade do Rio de Janeiro (Barroso 1957, 1959), Mucugê (Harley \& Simmons 1986) e Pico das Almas (Hind 1995) na Bahia, Chapada dos Veadeiros (Munhoz \& Proença 1998) em Goiás, Picinguaba (Moraes 1997), Fontes do Ipiranga (Nakajima et al. 2001) e em áreas de cerrado do estado de São Paulo (Almeida et al. 2005). Em Minas Gerais, constam os estudos de Nakajima \& Semir (2001) no Parque Nacional da Serra da Canastra, Hind (2003) em GrãoMogol, Almeida (2008) no Parque Estadual do Itacolomi, Teles (2008) com o estudo da tribo Astereae para o Brasil e Tribo Senecioneae para Minas Gerais, Borges (2008) com estudo da tribo Astereae no Parque Estadual do Ibitipoca e Hattori \& Nakajima (2008) na EPDA-Galheiro, Perdizes.

O objetivo do presente trabalho é o de realizar o tratamento sistemático da família Asteraceae na Reserva Ecológica do Panga, uma área com diversas fitofisionomias do cerrado.

\section{Material e métodos}

A Reserva Ecológica do Panga (REP) compreende uma área de 403,85 hectares e se localiza a cerca de $30 \mathrm{~km}$ ao sul do centro do município de Uberlândia, MG. Sua posição geográfica compreende as coordenadas $19^{\circ} 09^{\prime} 20^{\prime \prime}-19^{\circ} 11^{\prime} 10^{\prime \prime}$ Sul e $48^{\circ} 23^{\prime} 20^{\prime \prime}-48^{\circ} 24^{\prime} 35^{\prime \prime}$ Oeste, com uma altitude variando de 750 a 830 m (Schiavini \& Araújo 1989) (Figura 1). Os solos da região são classificados como Latossolo Vermelho e Latossolo Vermelho-Amarelo Profundo, bem drenado e com textura acentuadamente arenosa (Schiavini 1997), e solos hidromórficos de textura arenosa a intensamente ácidos, com características distróficas (Lima 1992). O clima, segundo a classificação de Köppen, é do tipo Aw, megatérmico, com verões chuvosos, que vão de outubro a março, e inverno seco que vão de abril a setembro, com temperatura média anual de $22{ }^{\circ} \mathrm{C}$ e pluviosidade anual de aproximadamente $1500 \mathrm{~mm}$ (Rosa et al. 1991). A Reserva Ecológica do Panga apresenta as seguintes fitofisionomias, de acordo com a classificação proposta por Ribeiro \& Walter (2008): floresta de galeria, floresta seca semidecídua, cerradão, cerrado sentido restrito, cerrado ralo, campo sujo seco, campo sujo úmido e vereda (figura 1).

Os exemplares examinados são provenientes de coletas realizadas desde o ano de 1986, e se encontram depositados no Herbarium Uberlandense (HUFU) da Universidade Federal de Uberlândia.
O tratamento sistemático consiste de uma chave de identificação geral para as espécies, seguido de suas descrições, com lista dos exemplares examinados, dados sobre distribuição nas fitofisionomias e comentários sobre distribuição geográfica e afinidades taxonômicas.

Para a tribo Eupatorieae, os gêneros utilizados no presente trabalho são os propostos por King \& Robinson (1987), uma vez que essa classificação tem consistência, principalmente quando se fala dos caracteres macromorfológicos para diferenciar os táxons, concordando assim com Hind $(1995,2003)$, Nakajima \& Semir (2001) e Esteves (2001). Para a tribo Vernonieae, utilizou-se o conceito amplo de Vernonia, uma vez que os caracteres utilizados por Robinson (1999) para separar os gêneros são variáveis

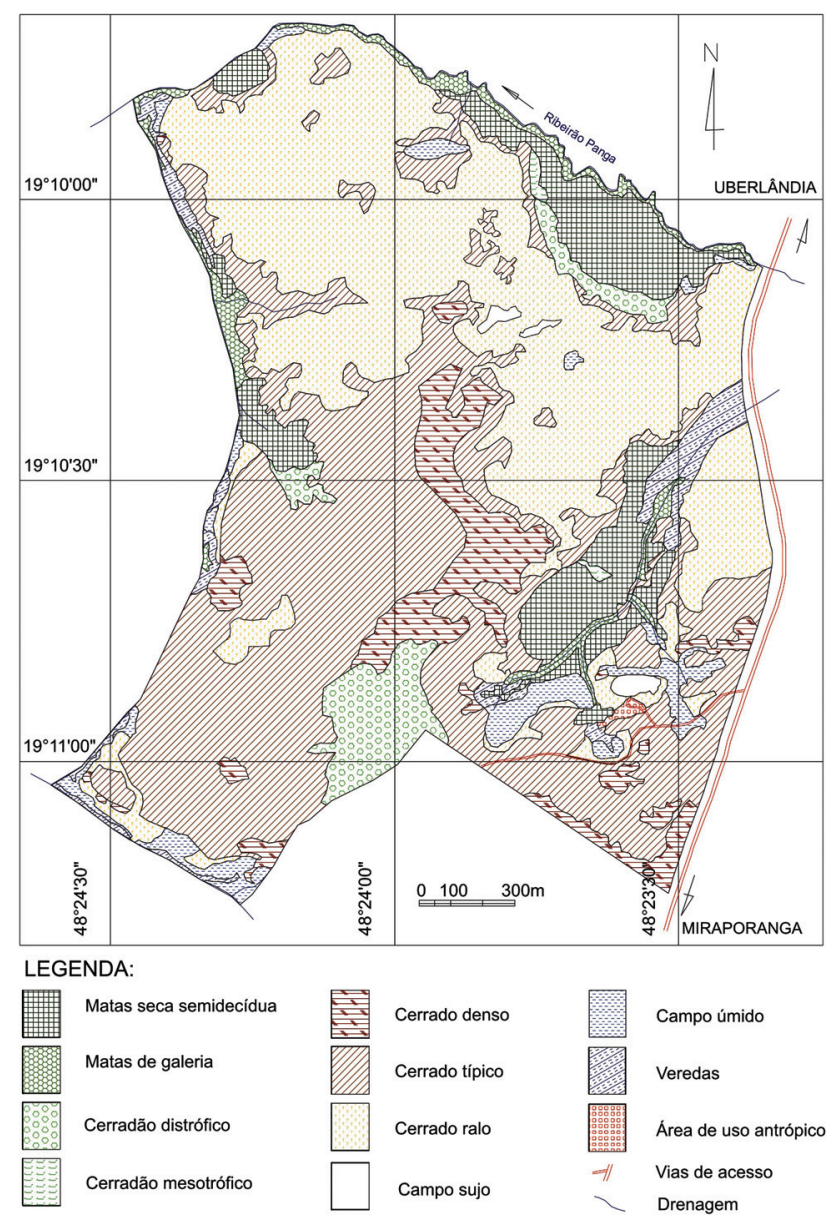

Figura 1. Diagrama esquemático com as fitofisionomias da Reserva Ecológica do Panga, Uberlândia, Minas Gerais. Retirado de: Cardoso et al. 2009.

Figure 1. Diagrammatic from Panga Ecological Reserve, Uberlândia, Minas Gerais state, showing the physiognomies. Taken from: Cardoso et al. 2009. 
em um táxon, e da mesma forma, não são exclusivos, concordando assim com Hind (1995, 2003), e Almeida (2008).

\section{Resultados e Discussão}

$\mathrm{Na}$ reserva foram encontradas 98 espécies pertencentes a 46 gêneros. Os gêneros com maior número de espécies foram: Vernonia (20 spp.), Chromolaena (10 spp.) e Baccharis (8 spp.), estando entre os mais representativos em outros estudos florísticos, principalmente no bioma Cerrado (Nakajima \& Semir 2001, Batalha 2001, Proença et al. 2001, Tannus \& Assis 2004, Almeida et al. 2005, Sasaki \& Mello-Silva 2008, Hattori \& Nakajima 2008).

Chave de identificação para as espécies de Asteraceae ocorrentes na Reserva Ecológica do Panga

1. Ramos com dois espinhos laterais ao pecíolo 35. Dasyphyllum brasiliense

1. Ramos sem espinhos laterais ao pecíolo

2. Plantas latescentes; flores com corola ligulada 54. Picrosia longifolia

2. Plantas não latescentes; flores com corola tubulosa, liguliforme, bilabiada ou filiforme

3. Anteras com apêndices basais, base calcarada, sagitada ou caudada

4. Estilete com pilosidade abaixo do ponto de bifurcação; anteras calcaradas

5. Capitulescências paniculiformes, corimbiformes, cinciformes ou capítulos solitários

6. Brácteas involucrais caducas; capítulos sésseis agrupados nas axilas das folhas

55. Piptocarpha rotundifolia

6. Brácteas involucrais persistentes, ou somente as mais internas caducas.

7. Capítulos com 35 flores ou mais

8. Capítulos solitários

9. Folhas até $2 \mathrm{~cm}$ compr., face abaxial esparso-setosa; capítulos sésseis 80. Vernonia brevifolia

9. Folhas com mais de $4 \mathrm{~cm}$ compr., face abaxial vilosa; capítulos pedicelados

84. Vernonia coriacea

8. Capítulos em cincínios folhosos

10. Folhas rosuladas na base; face abaxial das folhas alvo-lanosa 82. Vernonia buddleiifolia

10. Folhas alternas; face abaxial da folha não lanosa

11. Capítulos pedunculados, ca. 35 flores 79. Vernonia brasiliana

11. Capítulos sésseis, ca. 75-130 flores 77. Vernonia bardanoides

7. Capítulos com até 30 flores

12. Capítulos solitários; plantas ca. $0,15 \mathrm{~m}$ alt. 86. Vernonia desertorum

12. Capítulos em capitulescências; plantas com $0,4 \mathrm{~m}$ alt. ou mais

13. Plantas herbáceas

14. Brácteas involucrais esquarrosas, ápice esverdeado ....90. Vernonia herbacea

14. Brácteas involucrais imbricadas, ápice purpúreo

83. Vernonia cognata

13. Subarbustos ou arbustos

15. Capítulos com até 12 flores

16. Panículas definidas por grupos de 3-7 capítulos 85. Vernonia cuneifolia

16. Capítulos em cincínios

17. Folhas linear-lanceoladas a lanceoladas; invólucro cilíndrico 89. Vernonia fruticulosa

17. Folhas elípticas a ovadas; invólucro campanulado 18. Folhas com face abaxial gríseo-pubescente 87. Vernonia echitifolia 18. Folhas com face abaxial glandulosa 92. Vernonia obtusata 15. Capítulos com mais de 15 flores 
19. Plantas com folhas opostas na base 78. Vernonia beyrichii

19. Plantas com folhas alternas apenas

20. Capítulos em cincínios folhosos ao longo dos ramos

21. Folhas lineares 95. Vernonia rubricaulis

21. Folhas linear-lanceoladas a lanceoladas

22. Brácteas involucrais imbricadas; capítulos com 30 flores 81. Vernonia brevipetiolata

22. Brácteas involucrais esquarrosas; capítulos com 20 flores 91. Vernonia ligulifolia

20. Capítulos em cincínios folhosos formando panículas ou corimbos na porção apical dos ramos

23. Capítulos com ca. 25-30 flores

24. Folhas com a face abaxial alvo-tomentosa, margens inteiras a crenadas brácteas involucrais esverdeadas 88. Vernonia ferruginea

24. Folhas com a face abaxial esparso-estrigosa, margens levemente serreadas; brácteas involucrais púrpuras 96. Vernonia rubriramea

23. Capítulos com ca. 15-20 flores

25. Folhas sésseis; ramos sulcados; capítulos em panículas 94. Vernonia polyanthes

25. Folhas pecioladas; ramos angulosos; capítulos em corimbos 93. Vernonia petiolaris

5. Capitulescências glomeruliformes ou sinflorescências densas

26. Árvore; uma flor por capítulo 44. Eremanthus glomerulatus

26. Ervas ou subarbustos; 2-4 flores por capítulo

27. Glomérulos sem brácteas foliáceas na base 22. Chresta sphaerocephala

27. Glomérulos com uma série de brácteas foliáceas na base 28. Pápus 2-seriado; 2 flores por capítulo 38. Elephantopus biflorus

28. Pápus 1-seriado; 4 flores por capítulo

29. Pápus paleáceo; lobos da corola glandulosos 41. Elephantopus palustris

29. Pápus cerdoso; lobos da corola glabros

30. Pápus com espessamento na base; capítulos em glomérulos terminais 40. Elephantopus mollis

30. Pápus sem espessamento na base; capítulos em glomérulos axilares 39. Elephantopus erectus

4. Estiletes glabros abaixo do ponto de bifurcação; anteras de base caudada ou sagitada

31. Ramos do estilete bilobados, oblongos ou truncados

32. Capítulos com apenas um tipo de flor

33. Todas as flores tubulosas; receptáculo glabro

45. Gochnatia barrosii

33. Todas as flores bilabiadas; receptáculo cerdoso 75. Trixis glutinosa

32. Capítulos com dois ou três tipos de flor

34. Capítulos radiados, 3 tipos de flores diferentes 21. Chaptalia integerrima

34. Capítulos disciformes, dois tipos de flores diferentes

35. Flores centrais 2-3; ramos desprovidos de alas 3. Achyrocline satureioides

35. Flor central única; ramos alados.... 2. Achyrocline alata

31. Ramos do estilete lineares ou lanceolados

36. Capítulos em glomérulos terminais 63. Pterocaulon rugosum

36. Capítulos em glomérulos congestos formando espigas terminais 
37. Flores pistiladas ca. 35 ; ramos e face abaxial da folha lanuginosos

61. Pterocaulon alopecuroides

37. Flores pistiladas ca. 75; ramos e face abaxial da folha densamente lanosas

62. Pterocaulon lanatum

3. Anteras sem apêndices basais, base aguda ou obtusa

38. Brácteas involucrais conadas em quase toda a sua extensão

72. Tagetes minuta

38. Brácteas involucrais livres entre si, ou concrescidas apenas na base

39. Ramos do estilete com ápice truncado, penicelado

40. Flores róseas a vermelhas; invólucro acaliculado

42. Emilia sonchifolia

40. Flores amarelas; invólucro caliculado

43. Erechtites hieraciifolius

39. Ramos do estilete com ápice não truncado, com outros tipos de indumento

41. Flores marginais ou do raio pistiladas com corola filiforme ou liguliforme, ou

todas as flores pistiladas com corola filiforme, ou estaminadas com corola

tubulosa

42. Plantas dióicas

43. Plantas áfilas ou folhas reduzidas; ramos alados

9. Baccharis crispa

43. Plantas com folhas desenvolvidas; ramos cilíndricos

44. Capítulos solitários

45. Invólucro campanulado; folha linear-lanceolada

10. Baccharis dracunculifolia

45. Invólucro cilíndrico; folha lanceolada a oblanceolada

46. Invólucro do capítulo pistilado 7-8 $\mathrm{mm}$; pápus 6-8 $\mathrm{mm}$

14. Baccharis subdentata

46. Invólucro do capítulo pistilado 4-5 $\mathrm{mm}$; pápus até 4,5 $\mathrm{mm}$

16. Baccharis varians

44. Capítulos em panículas

47. Pápus das flores estaminadas sem ápice espessado .. 11. Baccharis humilis

47. Pápus das flores estaminadas com ápice espessado

48. Folhas com ápice mucronado; corola da flor pistilada glabra

15. Baccharis trinervis

48. Folhas com ápice não mucronado; corola da flor pistilada esparso-estrigosa a estrigosa

49. Arbusto; folhas trinervadas, vernicosas ...... 12. Baccharis illinita

49. Subarbusto; folhas uninervadas, não vernicosas

13. Baccharis rufescens

42. Plantas monóicas

50. Capítulos disciformes

51. Flores pistiladas 110-160; capítulos em panículas ...... 34. Conyza canadensis

51. Flores pistiladas ca. 25; capítulos solitários ............56. Podocoma bellidifolia

50. Capítulos radiados

52. Flores do disco perfeitas

71. Symphyotrichum regnellii

52. Flores do disco estaminadas por aborto do gineceu

53. Capítulos solitários em escapo floral.....

53. Capítulos em corimbos

48. Inulopsis camporum

49. Leptostelma maximum

41. Flores marginais ou do raio pistiladas, estaminadas ou neutras; corola liguliforme

ou tubulosa, ou todas as flores perfeitas, corola tubulosa

54. Flores amarelas ou alaranjadas; ramos do estilete com apêndices inconspícuos

55. Capítulos com todas as flores iguais, perfeitas 67. Spilanthes nervosa

55. Capítulos com flores marginais pistiladas ou do raio estaminadas ou neutras, e flores centrais ou do disco perfeitas, pistiladas ou estaminadas 
56. Capítulo com uma flor pistilada rodeada por várias flores estaminadas 66. Riencourtia oblongifolia

56. Capítulo com várias flores estaminadas ou perfeitas rodeadas por flores pistiladas ou neutras

57. Flores do raio pistiladas

58. Flores do raio pistiladas com corola liguliforme, flores do disco perfeitas 76. Verbesina glabrata

58. Flores do raio pistiladas com corola tubulosa ou filiforme, flores do disco estaminadas por aborto do gineceu 59. Flores do raio com pápus aristado 33. Clibadium armanii 59. Flores do raio sem pápus

60. Cipsela das flores pistiladas ornamentadas por ganchos; receptáculo plano ...... 1. Acanthospermum australe

60. Cipsela das flores pistiladas sem ganchos; receptáculo cônico 47. Ichthyothere mollis

57. Flores do raio neutras

61. Invólucro com brácteas subinvolucrais foliáceas

36. Dimerostemma lippioides

61. Invólucro sem brácteas subinvolucrais foliáceas

62. Invólucro campanulado

63. Folhas inteiras; pápus aristado-coroniforme

7. Aspilia foliacea

63. Folhas pinatífidas ou compostas 3-folioladas; pápus aristado com pelos retrorsos

64. Folhas pinatífidas; flores do raio alaranjadas; pápus 4-aristado 17. Bidens gardneri

64. Folhas compostas 3-folioladas; flores do raio amarelas; pápus 2-seriado 18. Bidens segetum

62. Invólucro globoso

65. Folhas pecioladas; pápus ausente 73. Tilesia baccata

65. Folhas sésseis; pápus aristado-coroniforme

66. Capítulos solitários; cipsela glabra nas flores do disco 97. Viguiera discolor

66. Capítulos em corimbos; cipsela serícea nas flores do disco 98. Viguiera robusta

54. Flores alvas, creme, róseas, violetas, lilases ou púrpuras; ramos do estilete com apêndices conspícuos

67. Capítulos com 4 flores; 4 brácteas involucrais

68. Plantas eretas; folhas sagitiformes a triangulares 52. Mikania officinalis

68. Plantas volúveis; folhas cordadas a ovadas ou lanceoladas

69. Lobos da corola glabros 50. Mikania cordifolia

69. Lobos da corola glandulosos

70. Capítulos em panículas; tubo da corola glabro

51. Mikania micrantha

70. Capítulos em racemos; tubo da corola glanduloso 53. Mikania psilostachya

67. Capítulos com 5 flores ou mais; 5 brácteas involucrais ou mais 71. Capítulos com 5 brácteas involucrais 
72. Brácteas involucrais híspidas, com tricomas glandulares 69. Stevia crenulata

72. Brácteas involucrais hirsutas, sem tricomas glandulares 68. Stevia collina

71. Capítulos com mais de 5 brácteas involucrais

73. Brácteas involucrais conadas na base; pápus paleáceo

4. Adenostemma suffruticosum

73. Brácteas involucrais livres; pápus cerdoso, plumoso, aristado ou ausente

74. Pápus cerdoso

75. Receptáculo cônico ou hemisférico

76. Brácteas involucrais persistentes; receptáculo hemisférico 20. Campuloclinium hirsutum

76. Brácteas involucrais caducas; receptáculo cônico

77. Folhas rosuladas na base; pápus purpúreo no ápice 57. Praxelis basifolia

77. Folhas opostas; pápus alaranjado, palhete ou alvo no ápice

78. Capítulos solitários; pedúnculo até $30 \mathrm{~cm}$; ápice da bráctea involucral purpúreo

60. Praxelis kleinioides

78. Capítulos em panículas ou corimbos; pedúnculo até $8,5 \mathrm{~cm}$; ápice da bráctea involucral esverdeada

79. Flores alvas; capítulos em panículas longas ..... 59. Praxelis grandiflora

79. Flores lilases; capítulos em corimbos 58. Praxelis clematidea

75. Receptáculo plano ou levemente convexo

80. Invólucro cilíndrico

81. Brácteas involucrais persistentes

82. Folhas sésseis, alternas.

19. Campovassouria cruciata

82. Folhas pecioladas, opostas

83. Folhas linear-lanceoladas

65. Raulinoreitzia tremula

83. Folhas elípticas-obovadas

64. Raulinoreitzia crenulata

81. Brácteas involucrais caducas na maturação dos frutos

84. Folhas alternas; até 5 flores por capítulo... 32. Chromolaena stachyophylla

84. Folhas opostas; mais de 5 flores por capítulo

85. Brácteas involucrais esbranquiçadas

27. Chromolaena leucocephala

85. Brácteas involucrais esverdeadas

86. Folhas glabras em ambas as faces

26. Chromolaena laevigata

86. Folhas com indumento estrigoso, setoso ou tomentoso em pelo menos uma das faces 
87. Folhas com glândulas em ambas as faces

88. Flores violetas; folhas sésseis a subsésseis 31. Chromolaena squalida

88. Flores alvas a creme; folhas pecioladas

89. Tubo da corola glanduloso; ramos do estilete estrigosos.

...... 23. Chromolaena brunneola

89. Tubo da corola glabro; ramos do estilete papiloso.

25. Chromolaena ferruginea

87. Folhas sem glândulas, ou apenas na face abaxial

90. Folhas com indumento estrigoso, sem glândulas.... 30. Chromolaena picta

90. Folhas com indumento setoso na face adaxial, com glândulas na face abaxial 91. Ápice das brácteas involucrais e tubo da corola com glândulas....

... 24. Chromolaena cylindrocephala

91. Ápice das brácteas involucrais e tubo da corola sem glândulas

92. Lâmina foliar ovallanceolada, invólucro 9-11 × $4 \mathrm{~mm}$; 30 flores no capítulo.

... 28. Chromolaena maximilianii

92. Lâmina foliar lanceolada ou elíptica; invólucro 6-7 $\times$ 2-3 mm; 20 flores no capítulo.

80. Invólucro campanulado

..29. Chromolaena perforata

93. Capítulos com 5 flores

94. Folhas sésseis; capítulos em corimbos densos 37. Disynaphia senecionidea

94. Folhas pecioladas; capítulos em panículas laxas 70. Stomatanthes trigonus 93. Capítulos com mais de 30 flores 
95. Folhas sésseis; capítulos em panículas 8. Ayapana amygdalina

95. Folhas curto-pecioladas; capítulos solitários. 46. Heterocondylus grandis

74. Pápus plumoso, aristado ou ausente 96. Corola e cipsela hirsutas, com glândulas sésseis 74. Trichogonia attenuata

96. Corola e cipsela glabras ou com glândulas estipitadas 97. Receptáculo epaleáceo; pápus aristado. 5. Ageratum conyzoides 97. Receptáculo paleáceo; pápus ausente 6. Ageratum fastigiatum

1. Acanthospermum australe (Loefl.) Kuntze, Revis. Gen. Pl. 1: 303. 1891.

Erva procumbente, 0,2-0,6 $\mathrm{m}$ alt.; ramos estriados, híspido-tomentosos. Folhas opostas, sésseis, lâmina 1-2,5 × 0,3-1,5 cm, ovada; ápice arredondado, margem serreada, base atenuada; face adaxial esparsoestrigosa, glandulosa, face abaxial esparso-setosa, glandulosa. Capítulos radiados, pedunculados, em panículas; invólucro campanulado, $3 \times 5 \mathrm{~mm}$; brácteas involucrais 2-seriadas, $3 \times 2 \mathrm{~mm}$, obovadas, setosas; ápice obtuso, margens ciliadas, base truncada; receptáculo plano, páleas oblanceoladas, setosas, conduplicadas, ápice fimbriado. Flores do raio ca. 8, pistiladas, amarelas, corola tubulosa, lobos glabros; ramos do estilete inconspícuos. Cipsela obovóide, 2-4 mm, uncinada, glandulosa; pápus ausente. Flores do disco 5-20, estaminadas, amarelas, corola tubulosa, lobos glandulosos; anteras de base aguda, apêndice ovado. Ovário abortivo, sem pápus.

Material examinado: BRASIL. Minas Gerais: Uberlândia, Reserva Ecológica do Panga, 4-III-1999, fl., fr., Araújo 2408 (HUFU); 21-I-2000, fl., fr., Araújo 3008 (HUFU); 20-I-1992, fl., fr., Barbosa 539 (HUFU).

Acanthospermum australe possui distribuição ampla na América do Sul. Esta espécie ocorre em vereda, campo sujo seco e campo sujo úmido na REP. A. australe é conhecida pela presença de ganchos na cipsela.

2. Achyrocline alata (Kunth) DC., Prodr. 6: 221. 1838.

Subarbusto, 0,5-1,5 m alt.; ramos cilíndricos, estriados, tomentosos ou lanosos, alas 0,5-2 mm larg. Folhas alternas, sésseis, lâmina 1,5-8,5 × 0,1-0,5 cm, linear-lanceolada; ápice longo-acuminado, margem inteira, revoluta ou plana, base truncada, decorrente no ramo; face adaxial lanosa, glandulosa, face abaxial lanoso-tomentosa. Capítulos disciformes em glomérulos, ramos em corimbos terminais densos; invólucro cilíndrico, 4-6 × 1-1,5 mm; brácteas involucrais 3 -seriadas, $3-5 \times 1 \mathrm{~mm}$, ovadas a lanceoladas, hialinas, amareladas, ápice acuminado, base lanosa, glandulosa; receptáculo plano. Flores marginais 4-5, pistiladas, creme, corola filiforme, $4 \mathrm{~mm}$, glabra; ramos do estilete lineares, glabros. Flor central única, perfeita, creme, corola tubulosa, tubo $3,5 \mathrm{~mm}$, glabro, lobos glandulosos; anteras de base caudada, ápice lanceolado; ramos do estilete truncados. Cipsela obovóide, $1 \mathrm{~mm}$, glabra; pápus cerdoso, 1-seriado, caduco, 3-4 $\mathrm{mm}$.

Material examinado: BRASIL. Minas Gerais: Uberlândia, Reserva Ecológica do Panga, 17-XII-1999, fl., fr., Amaral \& Cardoso s.n. (HUFU21848); 28-IV-2000, fl., fr., Araújo 3168 (HUFU); 26-V-2000, fl., fr., Araújo 3249 (HUFU); 26-III-1999, fl., bot., Araújo \& Barbosa s.n. (HUFU19581); 3-IV-1987, fl., fr., Araújo s.n. (HUFU997); 2-VI-2000, fl., fr., Araújo s.n. (HUFU23472); 30-VII-1999, fl., fr., Barbosa \& Mendes 2083 (HUFU); 28-V-1999, fl., fr., Lemos s.n. (HUFU20717); 25-VI-1999, fl., bot., Lemos s.n. (HUFU20764).

Achyrocline alata ocorre amplamente na América do Sul. Esta espécie é encontrada em mata de galeria e vereda na REP. Esta espécie ocorre em mata de galeria e vereda na REP. A. alata é muito parecida com $A$. satureioides, porém, esta não apresenta alas nos ramos.

3. Achyrocline satureioides (Lam.) DC., Prodr. 6: 220. 1837 [1838]. 
Subarbusto, 0,6-1 m alt.; ramos cilíndricos estriados, lanuginosos. Folhas alternas, sésseis, lâmina 1-5 × 0,2-1,2 cm, linear-lanceolada a lanceolada; ápice agudo ou acuminado, margem inteira, base aguda; face adaxial tomentosa a lanuginosa, glandulosa, face abaxial lanosa, glandulosa. Capítulos disciformes, em glomérulos, ramos em corimbos terminais densos, pedúnculo lanoso; invólucro cilíndrico, $5 \times 1,5-2 \mathrm{~mm}$; brácteas involucrais 3-seriadas, 3,5-5 × 1-1,5 mm, lanceoladas a linear-lanceoladas, hialinas, glabras, ápice acuminado, margens inteiras, base lanosa, glandulosa; receptáculo plano, alveolado. Flores marginais 7-9, pistiladas, creme, corola filiforme, tubo $4,5 \mathrm{~mm}$, glanduloso, ramos do estilete lineares, glabros. Flores centrais 2-3, perfeitas, creme, corola tubulosa, tubo 3,5 mm, glabra, lobos glandulosos; anteras de base caudada, apice oval-lanceolado; ramos do estilete lineares, truncados, pilosos. Cipsela obcônica a elipsóide, glabra; pápus cerdoso, 1-seriado, 4 mm.

Material examinado: BRASIL. Minas Gerais: Uberlândia, Reserva Ecológica do Panga, 19-XII-1986, fl., fr., Araújo s.n. (HUFU823); 15-I-1992, fl., fr., Barbosa 622 (HUFU); 22-I-1992, fl., fr., Barbosa 622 (HUFU); 7-V-2007, fl., bot., Hattori 737 (HUFU).

Achyrocline satureioides possui distribuição ampla na América do Sul. Esta espécie é encontrada em campo sujo seco e cerrado ralo na REP. A. satureioides é facilmente confundinda com A. alata pelo tipo de coflorescência e cor do capítulo, mas difere de $A$. alata pela característica já citada anteriormente.

4. Adenostemma suffruticosum Gardner, London J. Bot. 6: 433. 1847.

Figura 2

Subarbusto, 0,5-1,8 m alt.; ramos angulosos, puberulentos. Folhas opostas na porção inferior, alternas na porção superior, pecíolo $5-25 \mathrm{~mm}$, lâmina 1,5-15 × 0,5-10 cm, elíptica a oblanceolada; ápice acuminado ou agudo a obtuso, margem inteira a levemente crenada, base atenuada; ambas as faces glabras. Capítulos discóides, em panículas, pedúnculo 4-10 cm, invólucro hemisférico, 5-8 × 7-15 mm; brácteas involucrais 2-seriadas, conatas na base, 4-6 $\times 1-2 \mathrm{~mm}$, lanceoladas ou estreitamente oblongas, glutinosas, ápice agudo a obtuso, margens inteiras; receptáculo convexo. Flores 40-80, perfeitas, alvas, corola tubulosa, glandulosa, lobos tomentosos; anteras de base obtusa, ápice ausente; ramos do estilete longos, apêndices espatulados. Cipsela obcônica, glutinosa, 2-3 mm; pápus paleáceo, 3-4 páleas oblongas, $1 \mathrm{~mm}$, tricomas glandulares.

Material examinado: BRASIL. Minas Gerais: Uberlândia, Reserva Ecológica do Panga, 18-VI-1999, fl., fr., Araújo \& Faria s.n. (HUFU20431); 11-VII-1997, fl., fr., Araújo \& Mendes s.n. (HUFU18978); 10-IV-1992, fl., fr., bot., Araújo et al. 37 (HUFU, UEC); 15-V-1992, fl., fr., Araújo et al. 172 (HUFU); 26-V-2000, fl., fr., Barbosa 3380 (HUFU); 30-VII-1999, fl., fr., Barbosa \& S. Mendes 2086 (HUFU); 21-I-2000, fl., bot., Mendes s.n. (HUFU22268); 22-V-1987, fl., fr., Schiavini s.n. (HUFU1046).

Adenostemma sufruticosum é conhecida apenas na porção leste do Brasil, ocorrendo nos estados de Mato Grosso do Sul, Goiás, Minas Gerais e no Distrito Federal. Esta espécie é encontrada em campo sujo úmido, mata seca semidecídua e vereda na REP. A. suffruticosum pode ser reconhecida pelas brácteas involucrais glutinosas e conatas na base.

5. Ageratum conyzoides L., Sp. Pl. 2: 839. 1753.

Erva a subarbusto, 0,5-1,2 m alt.; ramos estriados, setosos. Folhas opostas, pecíolo 1-3,5 cm, densamente híspido, lâmina 1-4,5(8) × 0,5-4,5 mm, ovada; ápice agudo ou obtuso, margem crenada, base obtusa; face adaxial setosa, face abaxial setosa, glandulosa. Capítulos discóides, em corimbos densos, pedúnculo 5-15 mm; invólucro hemisférico, 4-5 × 4-5 mm; brácteas involucrais livres, 2-seriadas, 4-5 ×0,6-0,7 mm, lanceoladas, glabras ou setosas, ápice acuminado, margens serrilhadas; receptáculo convexo. Flores 6575 , perfeitas, alvas a purpúreas, corola tubulosa, glanduloso-estipitada, lobos tomentosos; anteras de base arredondada, ápice ovado; ramos do estilete obtusos. Cipsela obcônica, $2 \mathrm{~mm}$, glabra, 5-costada, serreada; pápus 5-aristado, base achatada, 2,5-3 mm.

Material examinado: BRASIL. Minas Gerais: Uberlândia, Reserva Ecológica do Panga, 5-VI-1992, fl., fr., Araújo et al. 209 (HUFU, RB); 21-V-1999, fl., fr., Barbosa s.n. (HUFU20142); 2-VI-2000, fl., fr., Barbosa s.n. (HUFU3440).

Ageratum conyzoides possui distribuição ampla na América do Sul. Esta espécie é encontrada em campo sujo úmido e vereda na REP e pode ser reconhecida pelo pápus 5 -aristado e as aristas com base achatada. 
6. Ageratum fastigiatum (Gardner) R.M. King \& H. Rob., Phytologia 24: 114. $1972 \equiv$ Alomia fastigiata Benth. ex Baker, Fl. bras. 6(2): 192. 1876.

Subarbusto, 0,5-1,5 m alt.; ramos estriados, puberulentos, glandulosos. Folhas alternas, sésseis, lâmina 1-8,5 × 0,1-1 mm, linear-lanceolada; ápice acuminado, margem inteira a serreada, às vezes levemente revoluta, base atenuada; face adaxial glandulosa; face abaxial glandulosa, nervuras setosas. Capítulos discóides, em corimbos densos, pedúnculo 5-10 mm, tomentoso, glanduloso; invólucro hemisférico, 3-4 × 3-4 mm; brácteas involucrais livres, 2-seriadas,
$3 \times 0,6-1 \mathrm{~mm}$, lanceoladas, setosas, glandulosas, ápice acuminado a agudo, margens ciliadas, receptáculo cônico, páleas espatuladas, 2-4 × 0,5-1 mm, glandulosas, ápice agudo, margens ciliadas. Flores 20-50, perfeitas, alvas a liláses, corola tubulosa, tubo 1,5-2 mm, glanduloso estipitado, lobos papilosos; anteras de base obtusa a arredondada, ápice ovado; ramos do estilete lineares, papilosos. Cipsela obcônica, 1-2 $\times 0,5 \mathrm{~mm}$, glabra, 5-costada; pápus ausente.

Material examinado: BRASIL. Minas Gerais: Uberlândia, Reserva Ecológica do Panga, 28-IV-2000, fl., bot., Araújo 3167 (HUFU); 10-IV-1992, bot., fl.,

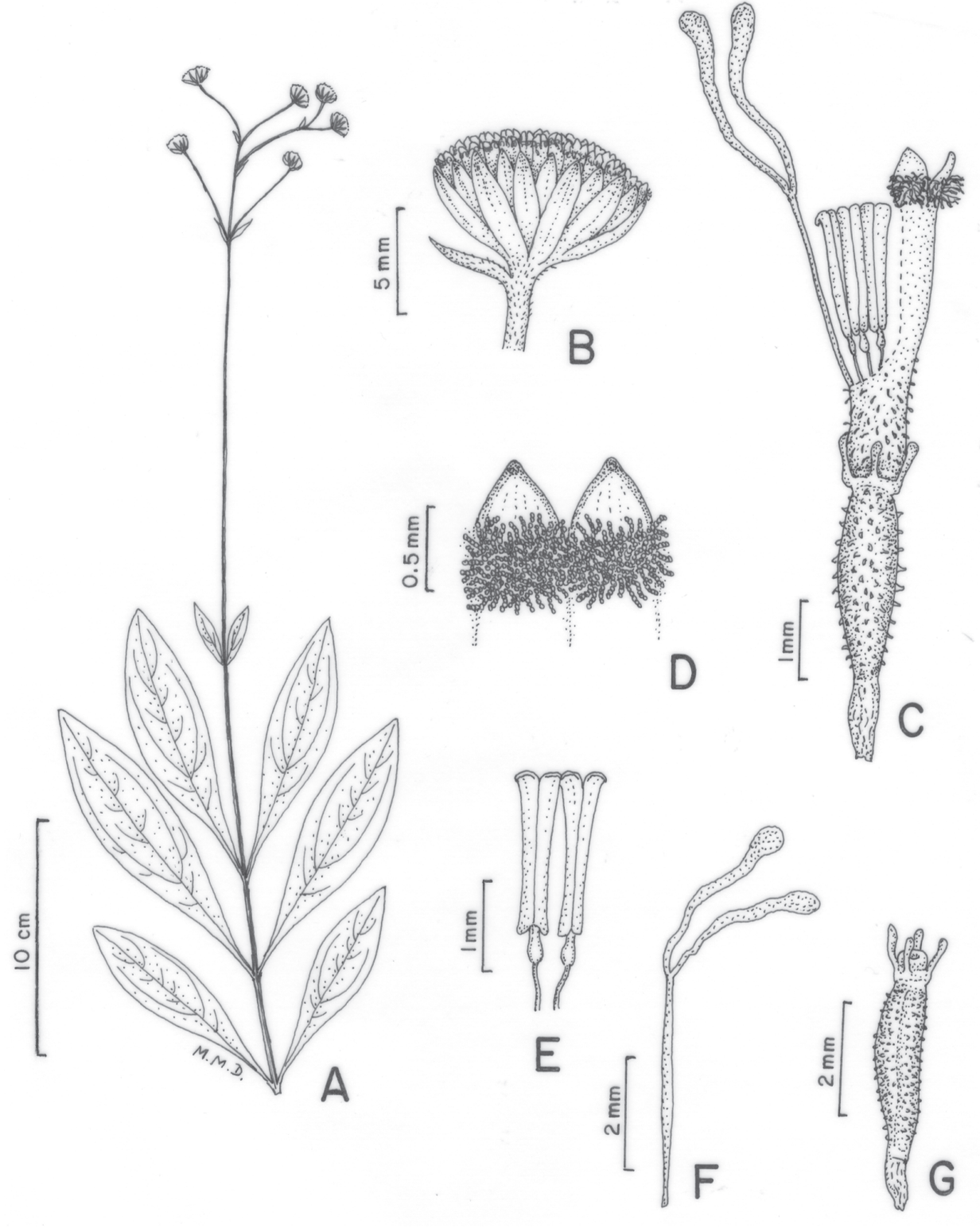

Figura 2. Adenostemma suffruticosum Gardner. A) Hábito; B) Capítulo; C) Flor, mostrando estilete e estames; D) Detalhe dos lobos da corola; E) Anteras; F) Ramos do estilete; G) Cipsela e Pápus. (Araújo et al. 118, HUFU3076).

Figure 2. Adenostemma suffruticosum Gardner. A) Habit; B) Head; C) Flower, showing style and stamens; D) Corola lobes in detail; E) Anthers; F) Style branches; G) Cypsela and Pappus. (Araújo et al. 118, HUFU3076). 
fr., Araújo et al. 17 (HUFU, RB, UEC); 8-V-1992, fl., fr., Araújo et al. 85 (HUFU, UEC); 11-IV-1997, fl., fr., Araújo s.n. (HUFU17991); 29-I-1999, fl., bot., Barbosa \& Amaral s.n. (HUFU18591); 27-VIII-1999, fl., fr., bot., Barbosa \& Mendes 2298 (HUFU); 3-VI-1988, fr., Carvalho 4 (HUFU); 11-XII-1998, fl., fr., Lemos s.n. (HUFU20279); 7-V-2007, fl., Hattori 730 (HUFU).

Ageratum fastigiatum ocorre somente no Brasil, nos estados da Bahia, Mato Grosso, Mato Grosso do Sul, Goiás, Minas Gerais, Espírito Santo, Rio de Janeiro, São Paulo, Paraná, Santa Catarina, Rio Grande do Sul e no Distrito Federal. Esta espécie ocorre em campo sujo úmido, campo sujo seco, transição cerrado sentido restrito-vereda e vereda na REP. A. fastigiatum é facilmente reconhecida pelas folhas alternas formando fascículos, dando um aspecto de folhas espiraladas.

7. Aspilia foliacea (Spreng.) Baker, Fl. bras. 6(3): 193. 1884.

Subarbusto, 0,3 m alt.; ramos delgados, estriados, híspidos. Folhas opostas, sésseis ou curto-peciolados, lâmina 1,5-4 ×0,5-1,6 cm, ovada a lanceolada; ápice acuminado a agudo, margem serreada, base arredondada; ambas as faces estrigosas. Capítulos radiados, em ramos candelabriformes, pedúnculo $7,5 \mathrm{~mm}$, densamente híspido; invólucro campanulado, 6-20 × 7-17 mm; brácteas involucrais 2-seriadas, lanceoladas, 7-15 × 2-4 mm, setosas, ápice agudo, margens ciliadas; receptáculo plano, páleas lanceoladas, conduplicadas, 7-8 × 1,5-2 mm, glabras, ápice acuminado, margens serrilhadas. Flores do raio ca. 10, neutras, amarelas, corola liguliforme, tubo 2-3 mm, limbo 19-23 × 5-6 mm. Ovário abortivo, fusiforme, 2-2,5 × $1 \mathrm{~mm}$, seríceo, costado; pápus aristado-coroniforme. Flores do disco ca. 40, perfeitas, amarelas, corola tubulosa, tubo 4-5 mm, glabro, lobos papilosos; anteras de base sagitada, ápice triangular; ramos do estilete lanceolados. Cipsela fusiforme, 2-3 $\times$ 1,2 $\mathrm{mm}$, serícea, comprimida; pápus aristadocoroniforme, aristas até $2 \mathrm{~mm}$.

Material examinado: BRASIL. Minas Gerais: Uberlândia, Reserva Ecológica do Panga, 2-X-1992, fl., bot., Araújo et al. 294 (HUFU, RB, UEC); 23-IX1992, fl., Barbosa 882 (HUFU).

Aspilia foliacea ocorre somente no Brasil, nos estados do Tocantins, Mato Grosso, Mato Grosso do Sul, Goiás, Minas Gerais, São Paulo, Paraná, Santa
Catarina, Rio Grande do Sul e no Distrito Federal. Esta espécie ocorre em campo sujo seco após fogo na REP. A. foliacea pode ser reconhecida pelos ramos delgados e capítulos dispostos em ramos candelabriformes.

8. Ayapana amygdalina (Lam.) R.M. King \& H. Rob., Phytologia 20(3): 211. 1970 三 Eupatorium amygdalinum Lam., Encycl. 2(2): 408. 1786 [1788].

Subarbusto, 1-1,5 m alt.; ramos estriados, híspidotomentosos. Folhas sésseis, lâmina 1-11,5 × 0,5-3,5 cm, lanceolada a elíptica, oblanceolada ou obovada; ápice agudo a arredondado, margem inteira a serreada, revoluta, base aguda a atenuada; ambas as faces escabras, híspido-tomentosas. Capítulos discóides, em panículas terminais, pedúnculo $5-10 \mathrm{~mm}$; invólucro cilíndrico, quando jovem, a campanulado, 6-9 $\times$ 5-9 mm; brácteas involucrais 3-4-seriadas, esquarrosas, 3-9 × 0,3-1,5 mm, lanceoladas a linear-lanceoladas, tricomas glandulares, ápice acuminado, purpúreo, margem ciliada; receptáculo plano. Flores 45-60, perfeitas, lilases, corola tubulosa, tubo 5,5-6,5 mm, glabro, lobos glandulosos; anteras de base aguda, ápice lanceolado; ramos do estilete lineares. Cipsela fusiforme, 2-2,5 × 0,4-0,7 mm, estrigosa, 5-costada, ciliada; pápus cerdoso, alvo, 1-seriado, 3-5 mm.

Material examinado: BRASIL. Minas Gerais: Uberlândia, Reserva Ecológica do Panga, 4-IX-1998, fl., fr., Barbosa 1063 (HUFU); 30-VIII-1999, fl., fr., Barbosa \& Mendes 2084 (HUFU); 31-VII-1997, fl., fr., Cardoso s.n. (HUFU18121); 24-VII-1997, fl., fr., Krauss 60 (HUFU); 29-VIII-1986, fl., fr., Schiavini s.n. (HUFU688).

Ayapana amygdalina ocorre nas Guianas, Suriname, Venezuela, Colômbia, Equador, Peru, Bolívia, Paraguai e no Brasil, ocorrendo em quase todas as regiões geográficas, exceto na Região Sul. Esta espécie ocorre em campo sujo seco e vereda na REP. A. amygdalina pode ser reconhecida pelas folhas oblanceoladas, híspido-tomentosas. O capítulo quando jovem é cilíndrico, diferente de quando herborizado, que se apresenta campanulado.

9. Baccharis crispa Spreng., Syst. Veg., edition decima sexta 3: 466. $1826 \equiv$ Baccharis trimera (Less.) DC., Prodr. 5: 425. 1836.

Erva dióica, 0,5-1 $\mathrm{m}$ alt.; ramos alados, angulosos, estriados, puberulentos, glandulosos, alas 2-9 mm larg., estrigosas, glandulosas, margens inteiras, levemente 
onduladas. Folhas reduzidas ou ausentes. Capítulos estaminados discóides, sésseis, em glomérulos, ramos em espigas interruptas; invólucro campanulado, $4 \times 4 \mathrm{~mm}$; brácteas involucrais $4-5$-seriadas, livres, 1-3 × 1-1,5 mm, ovadas a lanceoladas, glabras, ápice acuminado a agudo, margens serrilhadas, ciliadas; receptáculo plano, foveolado. Flores ca. 55, creme, corola tubulosa, tubo $3 \mathrm{~mm}$, glabra; anteras de base aguda, ápice lanceolado; ramos do estilete lanceolados, estrigosos. Cipsela abortiva; pápus cerdoso, 1-seriado, cerdas com ápice espessado, $4 \mathrm{~mm}$. Capítulos pistilados discóides, sésseis, em glomérulos, ramos em espigas interruptas; invólucro campanulado, $4 \times$ 4-5 $\mathrm{mm}$; brácteas involucrais 5-seriadas, 1-4 $\times$ 0,2-1,5 mm, amplo-ovadas a linear-lanceoladas, ápice acuminado a obtuso, margens serrilhadas, inteiras; receptáculo plano. Flores 70-80, creme, corola filiforme, tubo 2,5-3 mm, glabro; ramos do estilete lineares. Cipsela fusiforme a elipsóide, glabra, 10-costada, 0,5-1 × 0,2-0,5 mm; pápus 1-seriado, cerdas alvas, 3,5-4 $\mathrm{mm}$.

Material examinado: BRASIL. Minas Gerais: Uberlândia, Reserva Ecológica do Panga, 26-V-2000, bot., fl. ( + ), Barbosa 3376 (HUFU); 25-IV-1989, bot., fl. ( + ), Barbosa s.n. (HUFU2122, ICN).

Material adicional examinado: BRASIL. MinAs GERAIS: Ouro Branco, Serra do Ouro Branco, 9-VI-2002, fl. (o), Paula et al. 63 (HUFU, VIC).

Baccharis crispa ocorre na Bolívia, nordeste da Argentina, Paraguai, Uruguai e no Brasil, nos estados da Bahia, Goiás, Mato Grosso do Sul, Minas Gerais, Rio de Janeiro, São Paulo, Paraná, Santa Catarina, Rio Grande do Sul e no Distrito Federal. Esta espécie ocorre em vereda na REP. B. crispa é facilmente reconhecida pelos ramos alados.

10. Baccharis dracunculifolia DC., Prodr. 5: 421. 1836.

Subarbusto ou arbusto dióico, 1,5-3 m alt.; ramos cilíndricos, estriados, setosos ou tomentosos. Folhas alternas, sésseis, lâmina 0,6-3,5 × 0,1-0,6 mm, linearlanceolada; ápice agudo ou acuminado, margem inteira a dentada, base aguda; face adaxial glabra ou glandulosa, face abaxial glandulosa. Capítulos estaminados discóides, solitários, axilares, pedúnculo 3-6 mm; invólucro campanulado, 3-4 × 3,5-4 mm; brácteas involucrais livres, 3-seriadas, 1-3,5 $\times$ 0,8-1 mm, ovadas a lanceoladas, estrigosas, glandulosas, ápice agudo a acuminado, fimbriado, margens ciliadas; receptáculo plano a convexo. Flores 18-30, creme, corola tubulosa, tubo 2-2,5 mm, estrigoso ou setoso, lobos glabros; anteras de base aguda, ápice lanceolado; ramos do estilete bilobados, estrigosos. Cipsela abortiva; pápus cerdoso, 1-seriado, cerdas com ápice espessado, 3-4 mm. Capítulos pistilados discóides, solitários, axilares, pedúnculo 3-5 mm; invólucro campanulado, 3,5-7 × 4-5 $\mathrm{mm}$; brácteas involucrais 3-seriadas, 1-4,5 × $1 \mathrm{~mm}$, ovadas a lanceoladas, estrigosas, glandulosas, ápice agudo a acuminado, margens ciliadas; receptáculo convexo, foveolado. Flores 40-46, creme, corola filiforme, tubo 2,5-4 mm, glabro; ramos do estilete lineares. Cipsela elipsóide, 1-1,5 × 0,5-0,7 mm, 10-costada, glabra; pápus cerdoso, 1-seriado, cerdas 4-6 mm.

Material examinado: BRASIL. Minas Gerais: Uberlândia, Reserva Ecológica do Panga, 10-IV-1992, fl. ( क ), fr., Araújo et al. 4 (HUFU, UEC); 28-IV-2000, bot., fl. (o), Araújo 3172 (HUFU); 19-XII-1986, fl. (ㅇ), fr., Araújo s.n. (HUFU829); 27-II-1997, fl. (우), fr., Araújo s.n. (HUFU17988); 20-I-1992, fl. ( ( $\left.{ }^{\star}\right)$, Barbosa 542 (HUFU); 26-V-2000, fl. (o ), Barbosa 3374 (HUFU); 16-IV-1989, bot., fl. ( $\left.0^{\star}\right)$, Mendes 105 (HUFU).

Baccharis dracunculifolia ocorre na Bolívia, Paraguai, Argentina, Uruguai e no Brasil, nos estados da Bahia, Mato Grosso do Sul, Goiás, Minas Gerais, Rio de Janeiro, São Paulo, Paraná, Santa Catarina, Rio Grande do Sul e no Distrito Federal. Esta espécie ocorre em campo sujo seco, campo sujo úmido, cerrado sentido restrito, transição cerrado sentido restrito-vereda e vereda na REP. $B$. dracunculifolia é facilmente reconhecida em campo pelo odor característico de própolis quando está florescendo, pelas folhas lanceoladas e os capítulos axilares.

11. Baccharis humilis Sch. Bip. ex Baker, Fl. bras. 6(3): 92.1882.

Subarbusto dióico, com xilopódio, 0,15-0,2 m alt.; ramos cilíndricos, costados, glabros ou glandulosos. Folhas alternas, sésseis, lâmina 0,7-1,5 ×0,1-0,6 cm, oblanceolada a elíptica; ápice obtuso a arredondado, margem inteira ou dentada, base aguda a atenuada; ambas as faces glandulosas. Capítulos estaminados discóides, em panículas terminais, pedúnculo $8 \mathrm{~mm}$; invólucro campanulado, $4 \times 3 \mathrm{~mm}$; brácteas involucrais 3-seriadas, 3-4 × $1 \mathrm{~mm}$, lanceoladas a linearlanceoladas, glandulosas, ápice agudo a acuminado, margens fimbriadas; receptáculo convexo. Flores ca. 
20, creme, corola tubulosa, tubo $2 \mathrm{~mm}$, estrigoso, lobos glabros; anteras de base aguda, ápice ovado; estilete bilobado, estrigoso. Cipsela abortiva; pápus cerdoso, 1 -seriado, cerdas $4,5 \mathrm{~mm}$. Capítulos pistilados discóides, em panículas terminais, pedúnculo $4 \mathrm{~mm}$; invólucro campanulado, $5 \times 4 \mathrm{~mm}$; brácteas involucrais 3-seriadas, 2-4,5 × 1-1,5 mm, ovadas a lanceoladas, glandulosas, ápice obtuso, margens ciliadas; receptáculo plano. Flores ca. 20, creme, corola filiforme, tubo $3 \mathrm{~mm}$, estrigoso; ramos do estilete lineares. Cipsela obcônica, 1,5-2 × 0,5 mm, 10-costada, glabra; pápus cerdoso, 2-seriado, cerdas ca. $6 \mathrm{~mm}$.

Material examinado: BRASIL. Minas Gerais: Uberlândia, Reserva Ecológica do Panga, 24-IX-1992, bot., fl. (o), Araújo et al. 281 (HUFU, RB, UEC).

Material adicional examinado: BRASIL. Minas GeraIs: Uberlândia, Clube Caça e Pesca Itororó de Uberlândia: 3-X-1997, fl. ( ( ), fr., Araújo s.n. (HUFU16694).

Baccharis humilis ocorre apenas no Brasil, nos estados de Roraima, Acre, Mato Grosso, Mato Grosso do Sul, Goiás, Minas Gerais e no Distrito Federal em cerrados logo após queimadas. Esta espécie ocorre em cerrado sentido restrito na REP. B. humilis é facilmente reconhecida pelo xilopódio longo e pelos ramos curtos.

\section{Baccharis illinita DC., Prodr. 5: 412. 1836.}

Arbusto dióico, 1,5-2 m alt.; ramos cilíndricos, estriados, glabros a glandulosos. Folhas alternas, vernicosas, pecíolo até $4 \mathrm{~mm}$, lâmina 1,5-8 $\times$ 0,4-6,5 cm, obovada ou elíptica a oblanceolada, trinérvea; ápice obtuso a arredondado, margem 2-7-dentada, base atenuada, decorrente no pecíolo; ambas as faces glandulosas. Capítulos estaminados discóides, em panículas longas, pedúnculo $12 \mathrm{~mm}$, glanduloso; invólucro campanulado, 4-5 × 3-5 mm; brácteas involucrais 4-seriadas, 2-4,5 × 1-1,2 mm, ovadas a lanceoladas, glabras, ápice agudo a obtuso, margens serrilhadas; receptáculo convexo, foveolado, páleas oblongas, glabras, $5 \times 1 \mathrm{~mm}$, ápice obtuso, fimbriado, margens serrilhadas. Flores ca. 50, amarelas, corola tubulosa, tubo estrigoso, $3 \mathrm{~mm}$, lobos glabros; anteras de base obtusa, ápice lanceolado. Cipsela abortiva; pápus cerdoso, 1-seriado, cerdas $3 \mathrm{~mm}$, ápice espessado. Capítulos pistilados discóides, em panículas, pedúnculo $4 \mathrm{~mm}$; invólucro estreitocampanulado, 6-7 $\times 4-5 \mathrm{~mm}$; brácteas involucrais 4-seriadas, 3-5,5 × 1-1,5 mm, ovadas a lanceoladas, glabras, ápice glanduloso, agudo ou obtuso, margens ciliadas; receptáculo plano, foveolado. Flores ca. 40, creme, corola filiforme, tubo esparso-estrigoso, 3,5 mm; ramos do estilete lineares. Cipsela obcônica, $1 \times 0,5 \mathrm{~mm}, 10$-costada, glabra; pápus cerdoso, 1-seriado, cerdas ca. 5,5 mm.

Material examinado: BRASIL. Minas Gerais: Uberlândia, Reserva Ecológica do Panga, 26-V-2000, fl. ( $0^{\top}$ ), bot., Barbosa 3381 (HUFU); 9-VII-1999, fl. (ㅇ ), fr., Barbosa \& Faria s.n. (HUFU20886, ICN).

Baccharis illinita ocorre no Brasil, nos estados de Mato Grosso, Minas Gerais, São Paulo, Paraná, Santa Catarina e Rio Grande do Sul e no Distrito Federal. Esta espécie ocorre em vereda na REP. $B$. illinita pode ser reconhecida pelas folhas vernicosas e capítulos em panículas longas.

13. Baccharis rufescens Spreng., Syst. Veg. 3: 464. 1826.

Subarbusto dióico, 0,2-0,5 m alt.; ramos cilíndricos, estriados, glandulosos. Folhas alternas, sésseis, lâmina 0,7-3,5 $\times 0,3 \mathrm{~cm}$, linear a lanceolada ou oblanceolada, uninervada; ápice acuminado a agudo, margem inteira, base acuminada a atenuada; ambas as faces glandulosas. Capítulos estaminados discóides, em panículas, pedúnculo $7 \mathrm{~mm}$, glabro; invólucro campanulado, $4 \times 4 \mathrm{~mm}$; brácteas involucrais 3-4-seriadas, 2-4 × 0,8-1,2 mm, oval-lanceoladas a lanceoladas, glabras, ápice agudo a obtuso, margens ciliadas; receptáculo plano. Flores creme, corola tubulosa, tubo estrigoso, $2,5 \mathrm{~mm}$, lobos glabros; anteras de base aguda, ápice lanceolado; ramos do estilete lanceolados, estrigosos. Cipsela abortiva; pápus cerdoso, 1-seriado, cerdas alvas, $4 \mathrm{~mm}$, ápice espessado. Capítulos pistilados discóides, em panículas, pedúnculo $5 \mathrm{~mm}$; invólucro campanulado, $4 \times 2 \mathrm{~mm}$; brácteas involucrais 4-seriadas, 1,5-4,5 × 0,5-1 mm, ovadas a lanceoladas, glandulosas, ápice agudo, margens serrilhadas; receptáculo plano. Flores ca. 10, creme, corola filiforme, tubo $3 \mathrm{~mm}$, esparso-estrigoso; ramos do estilete lineares. Cipsela obcônica, 1-1,2 $\times$ 0,5 mm, 10-costada, glabra; pápus cerdoso, 1-seriado, cerdas conadas na base, ca. $5 \mathrm{~mm}$.

Material examinado: BRASIL. Minas Gerais: Uberlândia, Reserva Ecológica do Panga, 2-X-1992, bot., fl. (ㅇ), Araújo et al. 299 (HUFU, RB, UEC).

Material adicional examinado: BRASIL. MinAs GeRAIS: Baependi, Toca dos Urubus: 23-VI-2002, fl. ( $\left.0^{\star}\right)$, Ferreira \& Ferreira 180 (CESJ, HUFU). 
Baccharis rufescens ocorre na Paraguai, Argentina, Uruguai e Brasil, nos estados da Bahia, Mato Grosso do Sul, Minas Gerais, Rio de Janeiro, São Paulo, Paraná, Santa Catarina e Rio Grande do Sul. Esta espécie ocorre em campo sujo seco após fogo na REP. B. rufescens é reconhecida dentre as espécies ocorrentes do gênero na REP pelas folhas lineares a oblanceoladas.

14. Baccharis subdentata DC., Prodr. 5: 408. 1836.

Subarbusto dióico, 0,6-1,5 m alt.; ramos cilíndricos, angulosos ou estriados, glandulosos ou estrigosos. Folhas alternas, sésseis, lâmina $0,8-4 \times 0,1-0,9 \mathrm{~cm}$, lanceolada a oblanceolada; ápice agudo a obtuso, margem inteira ou dentada, base atenuada; ambas as faces glandulosas. Capítulos estaminados discóides, sésseis, solitários, axilares; invólucro cilíndrico, 5-7 × 3-4 mm; brácteas involucrais 3-4-seriadas, 1-6 $\times$ 0,8-1,2 mm, ovadas a lanceoladas, glabras, ápice agudo a obtuso, margens serrilhadas ou fimbriadas; receptáculo plano. Flores 9-18, creme, corola tubulosa, estrigosa, tubo 3,5-4,5 $\mathrm{mm}$; anteras de base aguda a obtusa, ápice lanceolado; ramos do estilete lanceolados, estrigosos. Cipsela abortiva; pápus cerdoso, 1-seriado, cerdas alvas, ápice espessado, 5-5,5 mm. Capítulos pistilados discóides, sésseis, solitários, axilares; invólucro cilíndrico, 7-8 × 2-3 mm; brácteas involucrais 3-5-seriadas, 1-7,5 $\times 1$-1,2 mm, ovadas a lanceoladas, ápice agudo ou obtuso, margens fimbriadas ou serrilhadas; receptáculo plano. Flores 10-12, creme, corola filiforme, glabra, tubo 5-7,5 mm; ramos do estilete lineares. Cipsela elipsóide, 1-1,5 × 0,4-0,6 mm, 10-costada, glabra; pápus cerdoso, 1 -seriado, cerdas alvas, concrescidas na base, $6-8 \mathrm{~mm}$.

Material examinado: BRASIL. Minas Gerais: Uberlândia, Reserva Ecológica do Panga, 22-V-1992, fl. (ㅇ ), fr., Araújo et al. 155 (HUFU, UEC); 27-IV-1992, (ㅇ, ơ) fl., fr., Barbosa 608 (HUFU); 13-V-1992, fl. ( + ), fr., Barbosa 692 (HUFU); 13-V-1993, fl. (क), fr., Barbosa $692 b$ (HUFU); 21-V-1999, fl. ( $0^{*}$ ), Faria s.n. (HUFU20410).

Baccharis subdentata ocorre apenas no Brasil, nos estados da Tocantins, Bahia, Mato Grosso, Mato Grosso do Sul, Goiás, Minas Gerais, São Paulo, Paraná, Santa Catarina e no Distrito Federal. Esta espécie ocorre em campo sujo seco, cerrado sentido restrito e vereda na REP. B. subdentata é muito semelhante a $B$. varians, porém, a primeira difere da segunda pelas folhas e capítulos maiores.
15. Baccharis trinervis (Lam.) Pers., Syn. Pl. 2: 423. 1807.

Subarbusto dióico, 0,5-1 m alt.; ramos cilíndricos, estriados, esparso-setosos, glandulosos. Folhas alternas, pecíolo 5-7 mm, lâmina 1-7 $\times 0,4-3 \mathrm{~cm}$, elíptica a lanceolada, trinervada; ápice agudo a obtuso, mucronado, margem inteira, base aguda; ambas as faces glabras. Capítulos estaminados discóides, em panículas, pedúnculo $8 \mathrm{~mm}$; invólucro campanulado, 3-4 × 4-5 mm; brácteas involucrais 3-4-seriadas, 1-3,5 × $1 \mathrm{~mm}$, ovadas a oblongas, glandulosas, ápice obtuso a arredondado, ciliado, margens inteiras; receptáculo cônico. Flores ca. 28, creme, corola tubulosa, tubo $2 \mathrm{~mm}$, estrigoso, lobos glabros; anteras de base obtusa, ápice lanceolado; ramos do estilete lanceolados, estrigosos. Cipsela abortiva; pápus cerdoso, 1-seriado, ápice espessado, 3,5 mm. Capítulos pistilados discóides, em panículas, pedúnculo $7 \mathrm{~mm}$; invólucro campanulado, $6 \times 5-6 \mathrm{~mm}$; brácteas involucrais 3-seriadas 2-5 × 0,6-1 mm, ovadas a lanceoladas, glandulosas, ápice acuminado a obtuso, margens serrilhadas; receptáculo convexo, alveolado. Flores creme, corola filiforme, glabra, tubo $3 \mathrm{~mm}$; ramos do estilete lineares. Cipsela fusiforme, 1,5-2 $\times$ 0,2-0,3 mm, glabra, 5-costada, ciliada; pápus cerdoso, 1 -seriado, cerdas alvas, $5 \mathrm{~mm}$.

Material examinado: BRASIL. Minas Gerais: Uberlândia, Reserva Ecológica do Panga, 20-III-1987, fl. (o ), Araújo s.n. (HUFU902).

Material adicional examinado: BRASIL. Mato Grosso Do Sul: Amambaí, Rio Amambaí: 20-III-2005, fl. ( ), fr., Pott \& Pott 12732 (HMS, HUFU).

Baccharis trinervis possui distribuição ampla na América do Sul. Esta espécie ocorre em mata seca semidecídua na REP. B. trinervis é facilmente reconhecida pelas folhas trinervadas, muito parecida com a nervação da folha de Dasyphyllum.

16. Baccharis varians Gardner, London J. Bot. 7: 84. 1848.

Subarbusto dióico, 0,5-1,5 m alt.; ramos cilíndricos, angulosos, estriados, glandulosos. Folhas alternas, sésseis, lâmina $0,8-3,3 \times 0,1-0,8 \mathrm{~cm}$, oblanceolada; ápice obtuso a arredondado, margem inteira, base atenuada; ambas as faces glandulosas. Capítulos estaminados discóides, sésseis, solitários, axilares; invólucro cilíndrico, 4,5 × $2 \mathrm{~mm}$; brácteas involucrais 3-4-seriadas, 1,5-4 × 1-1,2 mm, ovadas a lanceoladas, 
glabras, ápice agudo a obtuso, glanduloso, margens ciliadas; receptáculo convexo. Flores ca. 9, creme, corola tubulosa, tubo $2,5 \mathrm{~mm}$, estrigoso no ápice, lobos glabros; anteras de base obtusa, ápice lanceolado; ramos do estilete lanceolados, estrigosos. Cipsela abortiva; pápus cerdoso, 1-seriado, cerdas com ápice espessado, até $4 \mathrm{~mm}$. Capítulos pistilados discóides, sésseis, solitários, axilares; invólucro cilíndrico, 4-5× 1,5-3 $\mathrm{mm}$; brácteas involucrais 4-seriadas, $1-5 \times$ 0,8-1 mm, ovadas a linear-lanceoladas, glabras, ápice obtuso, margens ciliadas; receptáculo cônico. Flores ca. 10, creme, corola filiforme, tubo $3 \mathrm{~mm}$, esparsoestrigoso; ramos do estilete lineares. Cipsela elipsóide, $1 \times 0,5 \mathrm{~mm}, 8-10$-costada, glabra; pápus cerdoso, 1 -seriado, conado na base, cerdas filiformes, até $4,5 \mathrm{~mm}$.

Material examinado: BRASIL. Minas Gerais: Uberlândia, Reserva Ecológica do Panga, 18-II-2000, fl. (o ), Araújo 3053 (HUFU); 24-III-2000, fl. ( + ), Araújo 3113 (HUFU); 2-VI-2000, fl. ( + ), fr., Araújo s.n. (HUFU23468).

Baccharis varians ocorre na Argentina e Brasil, nos estados de Pernambuco, Bahia, Mato Grosso, Goiás, Minas Gerais, São Paulo e no Distrito Federal. Esta espécie ocorre em vereda na REP. B. varians é muito confundida com $B$. subdentata, e as diferenças entre estas duas espécies já foram discutidas anteriormente.

17. Bidens gardneri Baker, Fl. bras. 6(3): 246. 1884.

Erva, 0,5-1,5 $\mathrm{m}$ alt.; ramos angulosos, estriados, esparso-estrigosos a tomentosos. Folhas pinatífidas ou trilobadas, opostas, sésseis, lâmina 2-4 × 1,5-3, ovada; ápice agudo, margem serreada, base aguda a atenuada; ambas faces estrigosas, face abaxial com nervuras proeminentes. Capítulos radiados, solitários, pedúnculo 3-21 cm; invólucro campanulado, 6-8 × $10 \mathrm{~mm}$, tomentoso a viloso na base; brácteas involucrais 2-seriadas, 5-7 ×0,5-2 mm, lanceoladas, esverdeadas, estrigosas, ápice agudo, margens serrilhadas, púrpuras; receptáculo plano, páleas 6-6,5 × $1 \mathrm{~mm}$, linear-lanceoladas a lanceoladas, estriadas, planas, glabras, ápice agudo, estrigoso. Flores do raio 7-10, neutras, alaranjadas, corola liguliforme, glabra, tubo 1,5 mm, limbo 7-9 × 2,5-4 mm, estriado, ápice 2-dentado. Cipsela abortiva; pápus ausente. Flores do disco 35-60, perfeitas, amarelas, corola tubulosa, glabra, tubo 4-5,5 mm; anteras de base aguda, ápice ovado; ramos do estilete lineares, densamente estrigosos, ápice acuminado. Cipsela fusiforme, 2-2,5 × 0,5 mm, glabra, 4-angulosa; pápus 4-aristado, aristas retrorsas, $1,5-2,5 \mathrm{~mm}$.

Material examinado: BRASIL. Minas Gerais: Uberlândia, Reserva Ecológica do Panga, 10-IV-1992, bot., fl., fr., Araújo et al. 6 (HUFU, RB, UEC); 3-IV-1987, fl., fr., Castro s.n. (HUFU1006); 12-III-2007, bot., fl., fr., Hattori \& Vargas 536 (HUFU); 19-III-2007, bot., fl., fr., Hattori \& Vargas 548 (HUFU); 26-III-1999, fr., Lemos s.n. (HUFU20606).

Bidens gardneri ocorre no Paraguai e no Brasil, nos estados do Pará, Bahia, Mato Grosso, Mato Grosso do Sul, Goiás, Minas Gerais, São Paulo, Paraná e no Distrito Federal. Esta espécie ocorre em borda de cerradão, campo sujo, cerrado ralo, cerrado sentido restrito e vereda na REP, sendo facilmente reconhecida pelas folhas pinatífidas e flores do raio alaranjadas.

18. Bidens segetum Mart. ex Colla, Herb. Pedem. 3: 307. 1834.

Arbusto escandente; ramos cilíndricos, estriados, glabros. Folhas simples ou compostas trifolioladas, opostas, semi-amplexicaules, pecíolo 10-45 mm, lâmina da folha 2,5-10,5 × 0,5-3,5 cm, oval-lanceolada a lanceolada; ápice acuminado, margem serrilhada, base atenuada a decorrente no pecíolo nas folhas simples, ou na raque nas folhas compostas; ápice agudo a acuminado, margem serrilhada, base decorrente no pecíolo; face adaxial esverdeada, glabra, face abaxial alva a verde-clara, glabra. Capítulos radiados, em corimbos terminais, pedúnculo 5-60 mm; invólucro campanulado, 6-9 × 5-10 $\mathrm{mm}$; brácteas involucrais 2-seriadas, 4-7 × 0,5-1 mm, lanceoladas, glabras, ápice agudo, margens inteiras, ciliadas; receptáculo plano, páleas 8-10 × 1-1,2 mm, lineares a oblongas, planas, estriadas, ápice agudo ou obtuso, margens inteiras. Flores do raio 7-10, neutras, amarelas, corola liguliforme, tubo 2-2,5 mm, glabro, limbo $8-25 \times$ 2-5 mm. Cipsela abortiva; pápus ausente. Flores do disco 15-30, perfeitas, amarelas, corola tubulosa, glabra, tubo 6-7 mm; anteras de base sagitada, ápice triangular; ramos do estilete lineares, ápice acuminado. Cipsela fusiforme a turbinada, 1,5-2 × 0,4-0,6 mm, angulosa, bordos laterais vilosos; pápus 2-aristado, aristas retrorsas 2,5-4 mm.

Material examinado: BRASIL. Minas Gerais: Uberlândia, Reserva Ecológica do Panga, 21-IV-1999, fl., Arantes 1169 (HRCB, HUFU); 10-IV-1992, fl., 
fr., Araújo et al. 33 (HUFU); 27-III-1987, fl., fr., Araújo s.n. (HUFU1023); 27-IV-1992, fl., fr., bot., Barbosa 607 (HUFU).

Bidens segetum ocorre no Peru, Bolívia e Brasil, nos estados da Bahia, Goiás, Minas Gerais, Rio de Janeiro, São Paulo, Paraná, Santa Catarina e no Distrito Federal. Esta espécie ocorre em borda de mata de galeria, campo sujo e clareira em mata semidecídua na REP. B. segetum é facilmente reconhecida pelos ramos escandentes, folhas trifolioladas e flores do raio amarelas.

19. Campovassouria cruciata (Vell.) R.M. King \& H. Rob., Phytologia 49: 3. $1981 \equiv$ Eupatorium bupleurifolium DC., Prodr. 5: 149. 1836.

Subarbusto, 1,5-2 $\mathrm{m}$ alt.; ramos angulosos, estriados, ápice tomentoso. Folhas alternas, sésseis, lâmina 2-8,5 ×0,2 cm, linear-lanceolada; ápice acuminado, margem inteira, ciliada, base truncada; ambas as faces glandulosas. Capítulos discóides, em corimbos terminais densos, pedúnculo até $7 \mathrm{~mm}$; invólucro cilíndrico, $5 \times 1,5-2 \mathrm{~mm}$; brácteas involucrais persistentes, 3-seriadas, livres, 1,5-5 × 0,8-1,5 mm, lanceoladas a oblongas, esverdeadas, glabras ou glandulosas, ápice obtuso a arredondado, esverdeado, margens ciliadas; receptáculo plano. Flores 5, perfeitas, lilases, corola tubulosa, glandulosa, tubo $3 \mathrm{~mm}$; anteras de base aguda ou obtusa, ápice ovado a lanceolado; ramos do estilete lineares, estrigosos. Cipsela obcônica, 2-2,5 × 0,5-0,9 mm, glabra, 4-5-costada, ápice glanduloso; pápus cerdoso, 1 -seriado, cerdas alvas, ca. $3 \mathrm{~mm}$.

Material examinado: BRASIL. Minas Gerais: Uberlândia, Reserva Ecológica do Panga, 5-IX-1986, fl., fr., Schiavini s.n. (HUFU578); 15-IX-1997, bot., fl., Araújo 1793 (HUFU).

Campovassouria cruciata ocorre no sul da Bolívia, Paraguai, norte e centro da Argentina, Uruguai e no Brasil, nos estados de Mato Grosso do Sul, Distrito Federal, Minas Gerais, Rio de Janeiro, São Paulo, Paraná, Santa Catarina e Rio Grande do Sul. Esta espécie ocorre em vereda e transição campo sujo úmido-vereda na REP. C. cruciata é facilmente reconhecida pelas suas folhas alternas e linear-lanceoladas e os capítulos densamente agrupados em corimbos.

20. Campuloclinium hirsutum Gardner, London J. Bot. 6: 438. 1847 Eupatorium gardnerianum Hieron., Bot. Jahrb. Syst. 22: 758. 1897.
Subarbusto, ca. 0,6 m alt.; ramos cilíndricos, estriados, hirsutos, glandulosos. Folhas opostas, pecíolo até $6 \mathrm{~mm}$, lâmina 0,7-4,5 ×0,6-3 mm, ovada; ápice agudo a arredondado, margem serreada, base aguda ou obtusa, ambas as faces hirsutas, glandulosas. Capítulos discóides, em corimbos terminais, pedúnculo até $20 \mathrm{~mm}$; invólucro campanulado, 7-10 × 8-10 mm; brácteas involucrais ca. 20, 2-seriadas, livres, 8-10 $\times$ 3-5 mm, ovadas a oblanceoladas, estrigosas, glandulosas, esverdeadas, ápice obtuso, margem serrilhada, ciliada; receptáculo hemisférico. Flores ca. 40, perfeitas, róseas, corola tubulosa, setosa, tubo $4 \mathrm{~mm}$, lobos glandulosos; anteras de base arredondada, ápice orbicular; ramos do estilete lineares, papilosos. Cipsela obcônica, $4 \times 1 \mathrm{~mm}$, setosa, glandulosa, 5-costada, serreada; pápus cerdoso, 1-seriado, cerdas amarelas, ca. $4 \mathrm{~mm}$.

Material examinado: BRASIL. Minas Gerais: Uberlândia, Reserva Ecológica do Panga, 3-VI-1987, fl., fr., bot., Araújo s.n. (HUFU1018, HEPH); 12-III-2007, fl., bot., Hattori \& Vargas 528 (HUFU); 19-III-2007, fl., bot., Hattori \& Vargas 541 (HUFU).

Campuloclinium hirsutum ocorre apenas no Brasil, nos estados de Goiás, Minas Gerais, São Paulo e no Distrito Federal. Esta espécie ocorre em campo sujo seco e cerrado ralo na REP. C. hirsutum é facilmente reconhecida pelas brácteas involucrais em apenas duas séries e a série externa cobrindo quase que totalmente a série interna.

\section{Chaptalia integerrima (Vell.) Burkart,} Darwiniana 6(4): 576. 1944.

Erva, ca. 0,4 m alt.; ramos cilíndricos, costados, lanuginosos. Folhas rosuladas na base, sésseis, lâmina 45-100 × 10-25 mm, espatulada; ápice obtuso a agudo, margem inteira a levemente serrilhada, base atenuada, semi-amplexicaule; face adaxial aracnóide, face abaxial lanuginosa. Capítulos radiados, pedúnculo 16-30 cm, solitários; invólucro campanulado, 12-15 × 15-20 $\mathrm{mm}$; brácteas involucrais 4-5-seriadas, imbricadas, 7-13 × 1-1,5 mm, lanceoladas, tomentosas a lanuginosas, ápice acuminado a agudo, margem hialina; receptáculo plano, alveolado. Flores marginais pistiladas, creme, corola liguliforme, glabra, tubo $4 \mathrm{~mm}$, limbo $4 \times 0,2 \mathrm{~mm}$, ápice 3-dentado; ramos do estilete lineares, glabros. Flores intermediárias pistiladas, creme, corola filiforme; ramos do estilete lineares, glabros, ápice acuminado. Flores centrais perfeitas, creme, corola tubulosa, tubo $5 \mathrm{~mm}$, glabro, lobos 
papilosos; anteras de base caudada, ápice oblongo; ramos do estilete bilobados, papilosos. Cipsela fusiforme, $2 \times 0,2-0,3 \mathrm{~mm}$, glabra, costada, rostrada; pápus cerdoso, 1-seriado, cerdas filiformes, 6-7 $\mathrm{mm}$.

Material examinado: BRASIL. Minas Gerais: Uberlândia, Reserva Ecológica do Panga, 25-IX-1987, fl., bot., Araújo s.n. (HUFU1151).

Chaptalia integerrima ocorre amplamente na América do Sul. Esta espécie ocorre em campo sujo úmido na REP. C. integerrima pode ser reconhecida pelo capítulo esbranquiçado no ápice de um escapo floral longo e as folhas rosuladas na base.

22. Chresta sphaerocephala DC., Prodr. 5: 85. 1836.

Subarbusto, ca. $2 \mathrm{~m}$ alt.; ramos estriados, lanuginosos. Folhas alternas, pecíolo $25-35 \mathrm{~mm}$, lâmina 5,5-11 × 1,5-7,5 cm, ovada; ápice obtuso a arredondado, margem inteira, ondulada, levemente denticulada, base arredondada a truncada; ambas as faces lanuginosas. Capítulos discóides, sésseis, unidos em glomérulos terminais, escapo lanuginoso, até $15 \mathrm{~cm}$; invólucro turbinado, 8-9 × 2,5-3 mm; brácteas involucrais 4-5-seriadas, 2-2,5 $\times 0,8-1 \mathrm{~mm}$, densamente lanosas, 3-8 × 0,7-2 mm, lanceoladas, ápice agudo, margens serrilhadas; receptáculo plano. Flores 3, perfeitas, lilases, corola tubulosa, glabra, tubo 6-7,5 mm; anteras de base calcarada, calcarada, ápice oval-lanceolado; ramos do estilete pilosos abaixo do ponto de bifurcação, agudos. Cipsela turbinada, 2-2,5 $\times$ 1-1,5 mm, serícea; pápus cerdoso, 5-6-seriado, cerdas 3-8 mm.

Material examinado: BRASIL, Minas Gerais, Uberlândia, Reserva Ecológica do Panga, 22-VII-1993, fl., fr., Barbosa 697 (HUFU); 18-VII-1991, fl., fr., Schiavini 238 (HUFU).

Chresta sphaerocephala ocorre apenas no Brasil, nos estados da Bahia, Goiás, Minas Gerais, São Paulo, Paraná e no Distrito Federal. Esta espécie ocorre em campo sujo seco na REP. C. sphaerocephala é facilmente reconhecida pelas folhas ovadas, levemente amarronzado. Em alguns herbários é muito confundida com $C$. scapigera (Less.) Gardner, mas é diferente desta por não possuir folhas rosuladas na base e nem glabrescentes.

23. Chromolaena brunneola (Baker) R.M. King \& H. Rob., Phytologia 47: 230. 1980 三Eupatorium brunneolum Baker, Fl. bras. 6(2): 288. 1876.

Figura 3
Subarbusto, ca. 0,8 m alt.; ramos estriados, tomentosos. Folhas simples, opostas, pecíolo até $4 \mathrm{~mm}$ compr., lâmina 1,2-6 ×0,5-3,3 cm, elíptica; ápice agudo a obtuso, margem serreada, base atenuada a aguda; face adaxial esparso-setosa, glanduloso-pontuada, face abaxial tomentosa, glandulosa. Capítulos discóides, em cimas corimbiformes laxas terminais, pedúnculo $1 \mathrm{~cm}$; invólucro cilíndrico, $10 \times 3 \mathrm{~mm}$; brácteas involucrais caducas na maturação dos frutos, 6-seriadas, 1-8 $\times$ 1-1,5 mm, orbiculares a lineares, creme, glabras, ápice obtuso a arredondado, margens ciliadas; receptáculo levemente convexo. Flores ca. 30, perfeitas, creme, corola tubulosa, tubo 3,5-4 mm, glanduloso, lobos glandulosos; anteras de base obtusa, ápice lanceolado; ramos do estilete lineares, apêndices conspícuos, estrigosos. Cipsela obcônica, 3,5 × 0,7 mm, glabra, 5-costada, serreada; pápus cerdoso, 1 -seriado, cerdas ca. $5 \mathrm{~mm}$.

Material examinado: BRASIL. Minas Gerais: Uberlândia, Reserva Ecológica do Panga, 6-IV-1999, fl., fr., Arantes 1171 (HUFU, HRCB).

Chromolaena brunneola é conhecida apenas para o Brasil, e apenas para o estado de Minas Gerais (Barroso 1950). Esta espécie ocorre em borda de cerradão na REP. C. brunneola pode ser reconhecida pelos capítulos em cimas corimbiformes laxas.

24. Chromolaena cylindrocephala (Sch. Bip. ex Baker) R.M. King \& H. Rob., Phytologia 47: 230. $1980 \equiv$ Eupatorium cylindrocephalum Sch. Bip. ex Baker, Fl. bras. 6(2): 283. 1876.

Subarbusto, 1-1,5 $\mathrm{m}$ alt.; ramos angulosos, estriados, estrigoso-tomentosos. Folhas simples, opostas, pecíolo $5 \mathrm{~mm}$, lâmina 1-5,5 × 0,2-2 cm, lanceolada a oval-lanceolada; ápice acuminado a obtuso, margens inteiras a serreadas, levemente revolutas, base aguda a obtusa ou truncada; face adaxial setosa, face abaxial tomentosa, glandulosa. Capítulos discóides, em cimas corimbiformes, pedúnculo até $1 \mathrm{~cm}$; invólucro cilíndrico, 6-7 $\times$ 2,5-3 mm; brácteas involucrais livres, caducas na maturação dos frutos, 5-seriadas, 1,5-6 × 0,6-1,7 mm, ovadas a linear-lanceoladas, glabras, esverdeadas, ápice agudo a obtuso ou arredondado, glanduloso, tomentoso, margens serrilhadas, ciliadas; receptáculo levemente convexo. Flores 20-25, perfeitas, alvas ou violetas, corola tubulosa, tubo 3-4 mm, glabro ou glanduloso, lobos glandulosos; anteras de base aguda, ápice lanceolado; ramos do estilete lineares, papilosos, apêndices conspícuos. Cipsela obcônica, 2-4 × 
0,4-0,6 mm, glabra, 3-5-costada, serrilhada; pápus cerdoso, 1-seriado, cerdas alvas, 3-4 mm.

Material examinado: BRASIL. Minas Gerais: Uberlândia, Reserva Ecológica do Panga, 22-V-1992, fl., fr., Araújo et al. 144 (HUFU, RB); 16-IV-1999, fl., Araújo 2528 (HUFU); 29-IV-1997, bot., fl., fr., Araújo s.n. (HUFU17995); 7-IV-1992, fl., fr., Barbosa 600 (HUFU); 31-X-1986, fl., fr., Schiavini s.n. (HUFU763).
Chromolaena cylindrocephala ocorre apenas no Brasil, nos estados da Bahia, Mato Grosso, Minas Gerais e São Paulo. Esta espécie ocorre em campo sujo seco, cerrado sentido restrito, transição campo sujo úmido-campo sujo seco, transição cerrado sentido restrito-vereda e vereda na REP. C. cylindrocephala pode ser reconhecida pelas folhas lanceoladas com nervuras próximas a margem, e capitulescência folhosa.

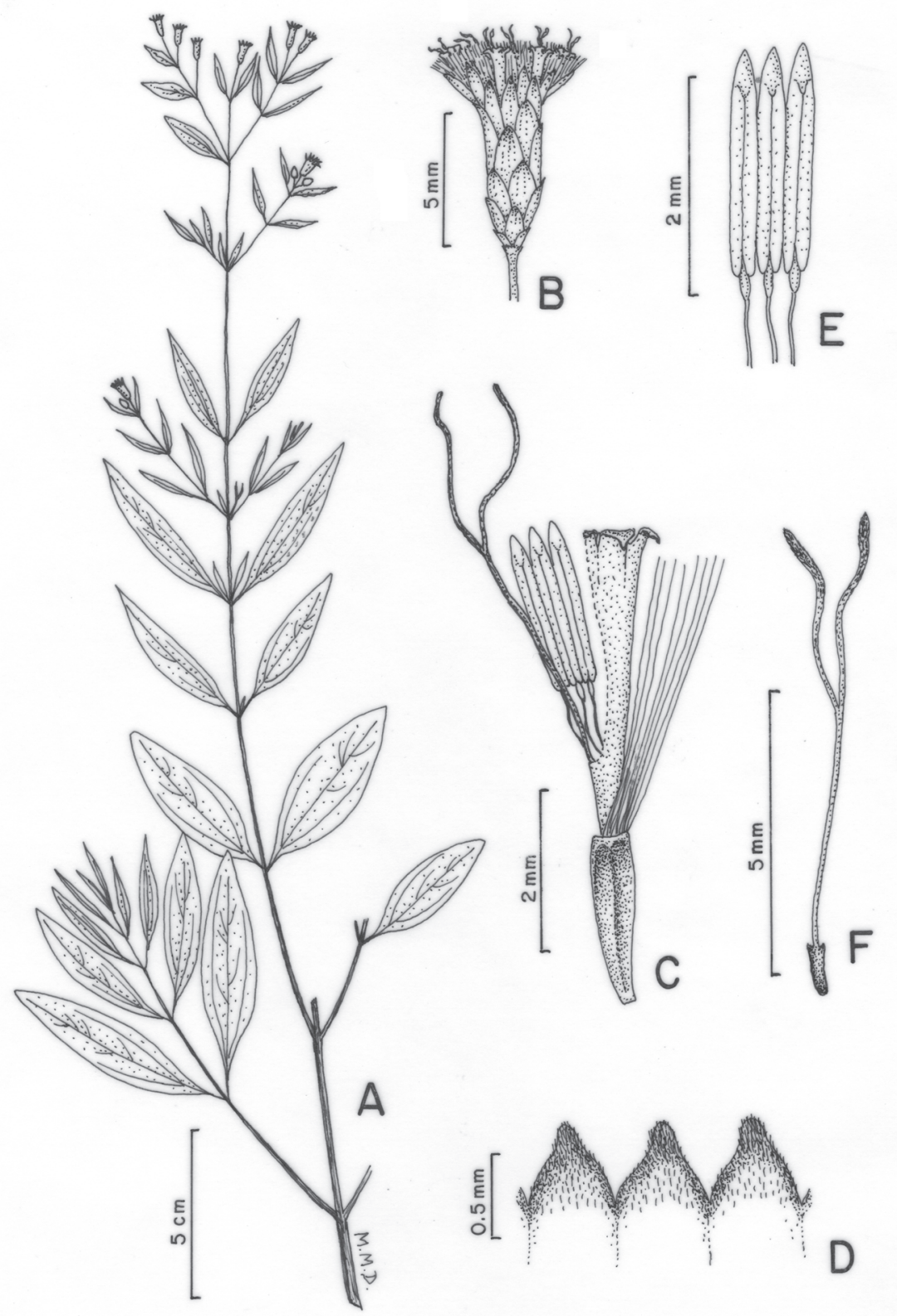

Figura 3. Chromolaena brunneola (Baker) R.M. King \& H. Rob. A) Hábito; B) Capítulo; C) Flor, mostrando estilete e estames; D) Detalhe dos lobos da corola; E) Anteras; F) Ramos do estilete. (Arantes 1171, HUFU25584).

Figure 3. Chromolaena brunneola (Baker) R.M. King \& H. Rob. A) Habit; B) Head; C) Flower, showing style and stamens; D) Corola lobes in detail; E) Anthers; F) Style branches. (Arantes 1171, HUFU25584). 
25. Chromolaena ferruginea (Gardner) R.M. King \& H.Rob., Phytologia 49: 4. 1981 三Eupatorium ferrugineum Gardner, Nov. Holl. Pl. 2: 88. t. 180. 1806.

Subarbusto, 1,2-1,5 m alt.; ramos estriados, estrigoso-tomentosos, glandulosos. Folhas simples, opostas, pecíolo até $8 \mathrm{~mm}$, lâmina 1,2-5 ×0,4-2,8 cm, ovada a oval-lanceolada; ápice obtuso, margem inteira a serreada ou crenada, base aguda a atenuada; face adaxial estrigosa, glandulosa, face abaxial tomentosa, glandulosa. Capítulos discóides, em cimas corimbiformes, pedúnculo até $7 \mathrm{~mm}$; invólucro cilíndrico, 6-8 × 3-3,5 mm; brácteas involucrais livres, caducas na maturação dos frutos, 6-7-seriadas, 1,5-7 $\times$ 0,7-1,2 mm, ovadas a lineares, glabras, esverdeadas, ápice obtuso a agudo, margem ciliada; receptáculo levemente convexo. Flores 20-35, perfeitas, alvas, corola tubulosa, tubo 3,5-4 mm, glabro, lobos glandulosos; anteras de base obtusa, ápice ovado; ramos do estilete lineares, papilosos, apêndices conspícuos. Cipsela obcônica, 3,5-4,5 × 0,5-0,8 mm, glabra, 5-costada, serreada; pápus cerdoso, 1-seriado, cerdas 5-5,5 $\mathrm{mm}$.

Material examinado: BRASIL. Minas Gerais: Uberlândia, Reserva Ecológica do Panga, 19-IV-1994, fl., fr., bot., Arantes \& Marra 160 (HUFU); 28-IV-2000, fl., fr., Araújo 3169 (HUFU); 22-IV-1997, fl., fr., Araújo s.n. (HUFU17994); 20-X-1993, fl., bot., Barbosa s.n. (HUFU12284); 21-V-2007, fl., fr., Hattori 747 (HUFU).

Chromolaena ferruginea ocorre apenas no Brasil, nos estados de Mato Grosso, Goiás, Minas Gerais, São Paulo e no Distrito Federal. Esta espécie ocorre em borda de vereda, campo sujo seco, cerrado sentido restrito, transição cerrado sentido restritovereda e vereda na REP. C. ferruginea pode ser reconhecida pelos capítulos agrupados em cimas corimbiformes formados por 3-5 capítulos.

26. Chromolaena laevigata (Lam.) R.M. King \& H. Rob., Phytologia 20(3): 202. $1970 \equiv$ Eupatorium laevigatum Lam., Encycl. 2(2): 408. 1786 [1788].

Subarbusto, 1,2-2,5 m alt.; ramos estriados, angulosos, glabros. Folhas simples, opostas, pecíolo até $15 \mathrm{~mm}$, lâmina 1,5-12 ×0,5-5 cm, lanceolada ou elíptica; ápice agudo, margem serreada, base aguda; ambas as faces glabras, glandulosas. Capítulos discóides, em cimas corimbiformes congestas, pedúnculo 9-20 mm; invólucro cilíndrico 8-11 $\times$
2,5-4 mm; brácteas involucrais livres, caducas na maturação dos frutos, 25-30, 5-6-seriadas, 1,5-9 × 0,6-2 mm, orbiculares ou ovadas a linear-lanceoladas, glabras, ápice obtuso a arredondado, margem inteira, ciliada; receptáculo levemente convexo. Flores 20-25, perfeitas, alvas a creme, corola tubulosa, tubo 4,5-5 mm, glabro, lobos papilosos; anteras de base aguda, ápice lanceolado; ramos do estilete lineares, apêndices conspícuos, papilosos. Cipsela obcônica 3-4 × 0,5-1 mm, glabra, 5-costada, serrilhada; pápus cerdoso, 1-seriado, cerdas amarelas, 4-5,5 mm.

Material examinado: BRASIL. Minas Gerais: Uberlândia, Reserva Ecológica do Panga, 15-V-1992, fl., fr., Araújo 109 (HUFU, RB, UEC); 23-IV-1999, fl., fr., bot., Araújo 2529 (HUFU); 28-IV-2000, fl., fr., Araújo 3186 (HUFU); 26-V-2000, bot., Araújo 3254 (HUFU); 8-V-1987, fl., fr., bot., Araújo s.n. (HUFU1048); 28-V-1999, fl., fr., bot., Araújo \& Faria s.n. (HUFU20186); 2-VI-2000, fl., fr., Araújo s.n. (HUFU23474); 7-V-2007, fl., fr., Hattori 733 (HUFU); 21-V-2007, fl., bot., Hattori 745 (HUFU).

Chromolaena laevigata ocorre no amplamente na América Tropical e no Brasil. Esta espécie ocorre em campo sujo úmido, transição cerrado sentido restrito-vereda e vereda na REP. C. laevigata é facilmente reconhecida por suas folhas lanceoladas, glabras, e os capítulos dispostos em cimas corimbiformes congestas.

27. Chromolaena leucocephala Gardner, London Journal of Botany 5: 465. $1846 \equiv$ Eupatorium calamocephalum (Baker) Hieron., Bot. Jahrb. Syst. 22: 761.1897.

Subarbusto, ca. 1,5 m alt.; ramos estriados, híspido-tomentosos, glandulosos. Folhas simples, opostas, pecíolo até $3 \mathrm{~mm}$, lâmina 0,5-3,5 × 0,3-2,5 cm, ovada a elíptica; ápice obtuso a arredondado, margem crenada a denteada, base arredondada a truncada; ambas as faces tomentosas, glandulosas. Capítulos discóides, em cimas corimbiformes, pedúnculo até $9 \mathrm{~mm}$; invólucro cilíndrico, 10-11 × 6-7 mm; brácteas involucrais livres, caducas na maturação dos frutos, ca. 75, 7-8-seriadas, 2-9 × 1-2 mm, ovadas a linearlanceoladas, esbranquiçadas, glabras, ápice obtuso a arredondado, esverdeado, margem inteira, receptáculo levemente convexo. Flores 20-25, perfeitas, lilases, corola tubulosa, tubo $5 \mathrm{~mm}$, glabro, lobos papilosos; anteras de base aguda, ápice ovado; ramos do estilete 
lineares, papilosos, apêndices conspícuos. Cipsela obcônica, $4 \times 1 \mathrm{~mm}$, glabra, 5-costada; pápus cerdoso, 1 -seriado, cerdas amareladas, ápice espessado, ca. $6 \mathrm{~mm}$.

Material examinado: BRASIL. Minas Gerais: Uberlândia, Reserva Ecológica do Panga, 22-V-1992, fl., bot., Araújo et al. 147 (HUFU, RB, UEC); 21-IV-1989, fl., bot., Barbosa s.n. (HUFU2064); 25-VI-1997, fl., fr., bot., Krauss 59 (HUFU); 7-V-2007, fl., bot., Hattori 736 (HUFU); 21-V-2007, fl., bot., Hattori 744 (HUFU).

Chromolaena leucocephala é citada apenas para o Brasil, nos estados de Mato Grosso, Goiás, Minas Gerais, São Paulo e no Distrito Federal. Esta espécie ocorre em campo sujo seco, cerrado ralo e cerrado sentido restrito na REP. C. leucocephala é caracterizada por possuir brácteas involucrais esbranquiçadas e folhas sésseis. É muito confundida com $C$. horminoides DC., que possui as brácteas involucrais mais internas violetas e folhas pecioladas.

28. Chromolaena maximilianii (Schrad. ex DC.) R.M. King \& H. Rob., Phytologia 49: 4. 1981 $\equiv$ Eupatorium maximiliani Schrad. ex DC., Prodr. 5: 143.1836.

Subarbusto, 0,5-1,5 m alt.; ramos cilíndricos, estriados, esparso-setosos. Folhas simples, opostas, pecíolo até $13 \mathrm{~mm}$, lâmina 1,5-7,5 × 0,4-2,8 cm, ovallanceolada; ápice acuminado, margem inteira ou serreada, levemente revoluta, base aguda ou obtusa; face adaxial setosa, face abaxial setosa, glandulosa. Capítulos discóides, em corimbos terminais, pedúnculo $2 \mathrm{~cm}$; invólucro cilíndrico, 9-11 × $4 \mathrm{~mm}$; brácteas involucrais livres, caducas na maturação dos frutos, ca. 35-40, 5-6-seriadas, 1,5-8 × 0,6-2 mm, orbiculares a linear-lanceoladas, glabras, ápice arredondado a obtuso, verde mais escuro, margem inteira a serrilhada, ciliada; receptáculo levemente convexo. Flores ca. 30, perfeitas, lilases, corola tubulosa, tubo 4-5 mm, glabro, lobos papilosos; anteras de base obtusa, ápice lanceolado; ramos do estilete lineares, papilosos, apêndices conspícuos. Cipsela obcônica, 4-5 $\times$ 0,3-0,5 mm, glabra, 5-costada, serrilhada; pápus cerdoso, 1-seriado, cerdas alvas, ca. $5 \mathrm{~mm}$.

Material examinado: BRASIL. Minas Gerais: Uberlândia, Reserva Ecológica do Panga, 22-V-1987, fl., fr., Araújo s.n. (HUFU1045); 3-VI-1988, fl., fr., bot., Carvalho s.n. (HUFU2751).
Chromolaena maximilianii ocorre na Guiana Francesa e amplamente no Brasil, com exceção da região Sul. Esta espécie ocorre em campo sujo seco na REP. C. maximilianii é facilmente reconhecida pelas folhas oval-lanceoladas e os capítulos em corimbos terminais em ramos candelabriformes.

29. Chromolaena perforata (Sch. Bip. ex Baker) R.M. King \& H. Rob., Phytologia 20: 205. 1970 E Eupatorium perforatum Sch. Bip. ex Baker, Fl. bras. 6(2): 289.1876.

Subarbusto, ca. $1 \mathrm{~m}$ alt.; ramos cilíndricos, estriados, estrigosos. Folhas simples, opostas, pecíolo até $7 \mathrm{~mm}$, lâmina 1,5-5,5 ×0,4-2 cm, lanceolada a elíptica; ápice acuminado ou agudo, margem inteira ou levemente serreada, revoluta, base acuminada ou atenuada; face adaxial setosa, face abaxial setosa, glandulosa. Capítulos discóides, em cimas corimbiformes terminais laxas, pedúnculo até $13 \mathrm{~mm}$; invólucro cilíndrico, 6-7 × 2-3 mm; brácteas involucrais livres, caducas na maturação dos frutos, ca. 30, 4-5-seriadas, 1,5-7 × 0,5-1 mm, ovadas a linearlanceoladas, glabras, ápice obtuso ou agudo, esverdeado, margens inteiras, ciliadas; receptáculo levemente convexo. Flores ca. 20, perfeitas, creme, corola tubulosa, tubo $4 \mathrm{~mm}$, glabro, lobos papilosos; anteras de base aguda, ápice ovado; ramos do estilete lineares, papilosos, apêndices conspícuos. Cipsela obcônica, $3 \times 0,5 \mathrm{~mm}$, glabra, 5-costada, serrilhada; pápus 1-seriado, cerdoso, cerdas $4 \mathrm{~mm}$.

Material examinado: BRASIL. Minas Gerais: Uberlândia, Reserva Ecológica do Panga, 6-IV-1999, fl., fr., Arantes 1172 (HUFU, HRCB); 24-III-1999, fl., fr., Arantes 1173 (HUFU).

Chromolaena perforata é conhecida apenas para o Brasil, e apenas para o Estado de Minas Gerais (Barroso 1950). Esta espécie ocorre em cerradão na REP. C. perforata pode ser confundida com C. brunneola por possuir capítulos em cimas corimbiformes laxas, mas difere desta por possuir folhas mais estreitas e face abaxial da folha mais glabrescente.

30. Chromolaena picta (Gardner) R.M. King \& H. Rob., Phytologia 47: 231. $1980 \equiv$ Eupatorium pictum Gardner, London J. Bot. 6: 443. 1847.

Arbusto, ca. 1,5 m alt.; ramos cilíndricos estriados, glandulosos. Folhas simples, opostas, pecíolo até $2 \mathrm{~cm}$, lâmina 2-8 × 0,7-3 cm, oval-lanceolada; ápice acuminado, margem serreada, base obtusa ou 
arredondada; face adaxial glabra, nervuras estrigosas, face abaxial estrigosa. Capítulos discóides, em corimbos terminais laxos, pedúnculo até $15 \mathrm{~mm}$; invólucro cilíndrico, 7-9 × 2,5-3 mm; brácteas involucrais livres, caducas na maturação dos frutos, ca. de 30, 5-6-seriadas, 1,5-8 × 1-2 mm, orbiculares a linear-lanceoladas, esvedeadas, glabras, ápice truncado ou arredondado, fimbriado, margem inteira, ciliadas; receptáculo levemente convexo. Flores ca. 25 , perfeitas, lilases, corola tubulosa, tubo $4 \mathrm{~mm}$, glabro, lobos glabros; anteras de base aguda ou obtusa, ápice lanceolado; ramos do estilete lineares, apêndices conspícuos, papilosos. Cipsela obcônica, $5 \times 0,4 \mathrm{~mm}$, glabra, 5-costada, serreada; pápus cerdoso, 1-seriado, cerdas alvas, ca. $5 \mathrm{~mm}$ compr.

Material examinado: BRASIL. Minas Gerais: Uberlândia, Reserva Ecológica do Panga, 28-VII-1999, fl., fr., Arantes 1025 (HRCB, HUFU).

Chromolaena picta é conhecida apenas para o Brasil, nos estados do Mato Grosso, Goiás, Minas Gerais e no Distrito Federal. Esta espécie ocorre em cerradão na REP. C. picta é muito semelhante a C. maximilianii, porém, difere desta por possuir a folha elíptica, e os capítulos agrupados em capitulescências menos congestas.

31. Chromolaena squalida (DC.) R.M. King \& H. Rob., Phytologia 20: 206. $1970 \equiv$ Eupatorium squalidum DC., Prodr. 5: 142. 1836.

Subarbusto, ca. 1,5 m alt.; ramos cilíndricos, costados, tomentosos, glandulosos. Folhas simples, opostas, sésseis a subsésseis, lâmina 1,5-4 × 0,5-1,5 cm, elíptica a ovada; ápice obtuso a agudo, às vezes mucronado, margem denteada, levemente revoluta, base obtusa ou aguda; face adaxial esparsoestrigosa, glanduloso-pontuada, face abaxial tomentosa, densamente glandulosa. Capítulos discóides, pedúnculo 2-7 mm, em cimas corimbiformes terminais laxas; invólucro cilíndrico, 7-9 × 2-3 mm; brácteas involucrais livres, caducas na maturação dos frutos, 5-6-seriadas, 25-35, glabras, ápice glabrescente, margens serrilhadas, ovadas a lanceoladas; receptáculo levemente convexo. Flores ca. 20, perfeitas, violetas, corola tubulosa, tubo $4 \mathrm{~mm}$, glabro, lobos glanduloso-pontuados; anteras de base arredondada, ápice ovado; ramos do estilete lineares, apêndices conspícuos, papilosos. Cipsela obcônica, $3 \times$ $0,7 \mathrm{~mm}$, glabra, 5-costada, serrilhada; pápus cerdoso, 1-seriado, cerdas filiformes, creme, ca. $4 \mathrm{~mm}$.
Material examinado: BRASIL. Minas Gerais: Uberlândia, Reserva Ecológica do Panga, 7-V-2007, fl., fr., bot., Hattori 727 (HUFU).

Chromolaena squalida ocorre na Colômbia, Equador, Peru, Bolívia, Paraguai, e amplamente no Brasil. Esta espécie ocorre em cerrado sentido na REP. C. squalida pode ser confundida com C. ferruginea, porém, difere desta por possuir folhas pecioladas, pelos capítulos agrupados de forma congesta, enquanto C. ferruginea possui folhas sésseis a subsésseis e capítulos laxos.

32. Chromolaena stachyophylla (Spreng.) R.M. King \& H. Rob., Phytologia 20: 206. 1970 $\equiv$ Eupatorium stachyophyllum Spreng., Syst. Veg. Fl. Peruv. Chil. 3: 420. 1826.

Subarbusto, ca. 0,5 m alt.; ramos cilíndricos, estriados, setoso-tomentosos, glandulosos. Folhas simples, alternas, pecíolo até $5 \mathrm{~mm}$, lâmina 1,3-4 $\times$ 0,3-1,5cm, lanceolada a elíptica; ápice agudo a arredondado ou obtuso, margem inteira ou levemente serreada, base aguda; ambas as faces com nervuras proeminentes, face adaxial esparso-setosa, face abaxial tomentosa, glandulosa. Capítulos discóides, sésseis em corimbos terminais densos; invólucro cilíndrico, $5 \times$ $3 \mathrm{~mm}$; brácteas involucrais livres, caducas na maturação dos frutos, 3-4-seriadas, 12-15, 3-5 × 1-2 mm, elípticas a lanceoladas, glabras, ápice agudo a obtuso, margem inteira ou serreada; receptáculo plano. Flores 5, perfeitas, lilases, corola tubulosa, tubo $4-5 \mathrm{~mm}$, setoso, lobos papilosos; anteras de base obtusa, ápice ovado a oval-lanceolado; ramos do estilete lineares, apêndices conspícuos, papilosos. Cipsela obcônica, 3,5 × 1-1,5 mm, setosa, glandulosa, 8-10-costada, ciliada; pápus cerdoso, 1-seriado, cerdas alvas, ca. $5 \mathrm{~mm}$.

Material examinado: BRASIL. Minas Gerais: Uberlândia, Reserva Ecológica do Panga, 4-IX-1994, fl., fr., bot., Barbosa 910 (HUFU).

Chromolaena stachyophylla ocorre no Piauí, Bahia, Mato Grosso, Mato Grosso do Sul, Goiás, Minas Gerais, São Paulo, Paraná e no Distrito Federal. Esta espécie ocorre em campo sujo seco pós-fogo na REP. C. stachyophylla difere de outras espécies do gênero encontradas na REP, por possuir folhas alternas e capítulos de menor tamanho.

33. Clibadium armanii (Balb.) Sch. Bip. ex O.E. Shulz, Bot. Jahrb. Syst. 46: 616. $1912 \equiv$ Clibadium rotundifolium DC., Prodr. 5: 505. 1836. 
Subarbusto a arbusto, 1-2 m alt.; ramos estriados, angulosos, híspidos, folhosos. Folhas simples, opostas, pecíolo até $13 \mathrm{~mm}$, lâmina 0,9-8 × 0,5-5,5 cm, ovada a oval-lanceolada; ápice obtuso a arredondado, margem serreada, base oblíqua ou arredondada; face adaxial estrigosa, face abaxial densamente estrigosa nas nervuras. Capítulos disciformes, sésseis, formando cimeiras terminais; invólucro campanulado, 4-6 $\times$ 3-4 mm; brácteas involucrais 3 , persistentes, 1-seriadas, 4-5,5 × 2,5-3 mm, ovadas, subcoriáceas, estrigosas, ápice agudo a obtuso, margens ciliadas; receptáculo convexo, páleas oblongas, 5-6 $\times 2-2,5 \mathrm{~mm}$, ápice obtuso, margens ciliadas. Flores do raio 3, pistiladas, corola filiforme, tubo 1,5-2 mm, glabro, lobos hirsutos; ramos do estilete glabros, lanceolados, apêndices inconspícuos. Cipsela elipsóide, 2-3 $\times$ 1,5-2 mm, ápice hirsuto; pápus 2-aristado, até $0,7 \mathrm{~mm}$. Flores do disco 7-15, estaminadas por aborto do gineceu, amarelas, corola tubulosa, tubo 2,5-3 mm, glabro, ápice 5-lobado, lobos hirsutos; anteras de base sagitada, ápice ovado. Cipsela turbinada, abortiva, hirsuta; pápus ausente.

Material examinado: BRASIL. Minas Gerais: Uberlândia, Reserva Ecológica do Panga, 21-I-2000, fl., fr., Araújo 3007 (HUFU); 18-II-2000, fl., fr., Araújo 3051 (HUFU); 16-V-2000, bot., fl., fr., Araújo 3248 (HUFU); 8-XII-1998, fl., fr., Araújo \& Barbosa 2052 (HUFU); 29-V-1992, fl., fr., Araújo et al. 184 (HUFU, RB, UEC); 13-II-1987, fl., fr., Araújo s.n. (HUFU815, HEPH); 7-II-1997, fl., fr., Araújo s.n. (HUFU17987); 11-IV-1997, fl., fr., Araújo s.n. (HUFU17992); 17-XII-1999, fl., fr., Barbosa 3081 (HUFU); 28-IV-2000, fl., fr., Barbosa 3550 (HUFU); 31-VII-1997, fl., fr., Cardoso s.n. (HUFU18120); 12-II-2007, bot., fl., Hattori \& Vargas 516 (HUFU); 10-XII-1993, fl., fr., Romero \& Arantes 567 (HUFU).

Clibadium armanii ocorre no Paraguai e no Brasil, nos estados do Tocantins, Bahia, Mato Grosso do Sul, Goiás, Minas Gerais, São Paulo, Rio de Janeiro, Paraná e no Distrito Federal. Esta espécie ocorre em campo sujo seco, campo sujo úmido, transição campo sujo úmido-campo sujo seco, transição cerrado sentido restrito-vereda, e vereda na REP. C. armanii é caracterizada por possuir capítulos disciformes com flores pistiladas com corola filiforme, podendo ser confundida com Ichthyothere, porém, difere desta pela nervação da folha, peninervada e os capítulos em cimeiras em Clibadium e curvinérvea e capítulos em corimbos em Ichtthyothere.
34. Conyza canadensis (L.) Cronquist, Bull. Torrey Bot. Club 70(6): 632. 1943 = Erigeron canadensis L., Sp. Pl. 2: 863. 1753.

Subarbusto, 1-2 m alt.; ramos angulosos, estriados, glabros a esparso-setosos. Folhas simples, alternas, sésseis, lâmina 0,8-8 × 0,1-0,5 cm, linear-lanceolada; ápice acuminado, margem inteira a serreada, base atenuada; ambas as faces setosas, glandulosas. Capítulos disciformes, em panículas, pedúnculo $1 \mathrm{~cm}$; invólucro campanulado, 3-4 × 4-5 mm; brácteas involucrais persistentes, 2-3-seriadas, $1-4 \times 0,5-0,8 \mathrm{~mm}$, linear-lanceoladas a lanceoladas, glandulosas, esparsosetosas, ápice acuminado, margem inteira; receptáculo plano. Flores marginais 110-160, pistiladas, creme, corola filiforme, tubo 2-3,5 $\mathrm{mm}$, glabro, ápice 2-4-lobado; ramos do estilete lineares, glabros. Cipselas elipsóides, estrigosas, $1 \times 0,5 \mathrm{~mm}$; pápus cerdoso, 1-seriado, cerdas filiformes, barbeladas, $3 \mathrm{~mm}$. Flores centrais 13-18, perfeitas, amarelas, corola tubulosa, tubo 2-3,5 mm, glabro, lobos glabros; anteras de base aguda, ápice oblongo; ramos do estilete lineares, estrigosos. Cipselas fusiformes, comprimidas, estrigosas, $1 \times 0,5 \mathrm{~mm}$; pápus cerdoso, 1-seriado, cerdas filiformes, 3-4 mm.

Material examinado: BRASIL. Minas Gerais: Uberlândia, Reserva Ecológica do Panga, 19-XI-1999, fl., fr., Araújo 2919 (HUFU); 13-II-1987, fl., fr., Araújo s.n. (HUFU828); 15-I-1992, fl., bot., Barbosa 554 (HUFU); 8-XII-1998, fl., fr., Barbosa \& Araújo 2053 (HUFU); 30-IV-1999, bot., fl., fr., Barbosa \& Faria 2017 (HUFU).

Conyza canadensis possui distribuição pantropical, desta maneira, possui ampla distribuição na América do Sul e no Brasil. Esta espécie ocorre em campo sujo seco, campo sujo úmido e vereda na REP. C. canadensis é facilmente conhecida pelos capítulos pequenos dispostos em panículas ao longo dos ramos.

35. Dasyphyllum brasiliense (Spreng.) Cabrera, Revista Mus. La Plata, Secc. Bot. 9(38): 72, 74. 1959.

Arbusto, ca. $3 \mathrm{~m}$ alt.; ramos estriados, glabros, com espinhos axilares. Folhas simples, alternas, pecíolo até $7 \mathrm{~mm}$, lâmina 3-12 × 1,5-5,5 cm, obovada, elíptica ou lanceolada; ápice agudo ou arredondado, mucronado, margem inteira, ondulada, levemente revoluta, base atenuada ou aguda; ambas as faces 
glabras. Capítulos discóides, em panículas terminais, pedúnculo $7 \mathrm{~mm}$, tomentoso; invólucro cilíndricoturbinado, $11-13 \times 4-5 \mathrm{~mm}$; brácteas involucrais persistentes, 5-6-seriadas, imbricadas, 2-11 $\times 1-2 \mathrm{~mm}$, orbiculares a ovadas, oval-lanceoladas a linearlanceoladas, ápice acuminado, mucronado, setoso ou glabrescente, margem ciliada, obtuso a agudo, margens ciliadas; receptáculo plano, piloso. Flores ca. 10, perfeitas, bege, corola tubulosa com duas incisões mais profundas que as demais, tubo $3,5 \mathrm{~mm}$, glabro, lobos densamente setosos no ápice; anteras de base aguda, ápice ausente; ramos do estilete bilobados, glabros. Cipselas turbinadas, $2 \times 1,5 \mathrm{~mm}$, densamente vilosas; pápus plumoso, 1-seriado, marrom, amarelo no ápice, 8-9 $\mathrm{mm}$.

Material examinado: BRASIL. Minas Gerais: Uberlândia, Reserva Ecológica do Panga, 12-VIII-1987, fl., fr., Schiavini s.n. (HUFU1063).

Dasyphyllum brasiliense possui ampla distribuição geográfica, ocorrendo desde as áreas limítrofes com o Peru, Bolívia, Paraguai e Argentina, até a Bahia e as regiões Central e Sul do Brasil. Esta espécie ocorre em mata de galeria na REP. D. brasiliense é facilmente conhecida pelo hábito escandente, espinhos axilares e as folhas com nervuras próximas a margem.

36. Dimerostemma lippioides (Baker) S.F. Blake, Contr. Gray Herb. 52: 13. 1917.

Subarbusto, ca. $0,8 \mathrm{~m}$ alt.; ramos estriados, estrigoso-tomentosos. Folhas simples, opostas, pecíolo até $5 \mathrm{~mm}$, lâmina $1-5 \times 0,7-4 \mathrm{~cm}$, ovada a cordada ou rotunda; ápice obtuso ou arredondado; margem serreada ou crenada, base obtusa ou cordada; face adaxial estrigosa, glandulosa, face abaxial estrigosotomentosa, glandulosa. Capítulos radiados, em umbelas longas terminais, pedúnculo ca. $6 \mathrm{~cm}$, estrigoso-tomentoso; invólucro hemisférico, 5-8 $\times$ 7-10 mm, com 1 série de brácteas subinvolucrais foliáceas; brácteas involucrais livres, persistentes, 2-seriadas, 5-8 $\times$ 2-3, oblongas a elípticas, estrigosas a tomentosas, glandulosas, ápice agudo ou obtuso, margem serreada ou crenada, ciliada; receptáculo convexo, páleas conduplicadas, glabras, 7-8 $\times 4 \mathrm{~mm}$, ápice agudo, margem serrilhada. Flores do raio 10-13, neutras, amarelas, corola liguliforme, tubo curto, estrigoso, limbo 5-11 $\times$ 2-4 mm, estrigoso. Cipselas turbinadas, $3 \times 1,5 \mathrm{~mm}$, glabras, 3 -angulosas, serreadas; pápus aristado-paleáceo, $2 \mathrm{~mm}$. Flores do disco
50-70, perfeitas, amarelas, corola tubulosa, tubo 4-4,5 mm, glabro, lobos estrigosos no ápice; anteras de base sagitada, ápice ovado; ramos do estilete estrigosos, lanceolados, apêndices inconspícuos. Cipselas turbinadas, comprimidas $3,5 \times 1 \mathrm{~mm}, 4$-costadas, ciliadas; pápus aristado-paleáceo, ca. $3 \mathrm{~mm}$.

Material examinado: BRASIL. Minas Gerais: Uberlândia, Reserva Ecológica do Panga, 20-I-1992, fl., bot., Barbosa 541 (HUFU); 4-III-1998, fl., fr., Barbosa \& Araújo s.n. (HUFU1419, UEC); 19-I-1993, fl., fr., bot., Melo et al. 19 (HUFU, RB, UEC).

Dimerostemma lippioides é restrita apenas para o Brasil, nos estados do Goiás, Minas Gerais, e algumas regiões locais na Bahia, Mato Grosso, São Paulo e no Distrito Federal. Esta espécie é encontrada em campo sujo seco e cerradão na REP. D. lippioides pode ser reconhecida pelas folhas cordadas a rotundas e os capítulos com pedúnculos longos, dispostos em umbelas.

37. Disynaphia senecionidea (Baker) R.M. King \& H. Rob., Phytologia 22: 124. 1971 E Eupatorium senecionideum Baker, Fl. bras. 6(2): 335. 1876.

Subarbusto, ca. $1 \mathrm{~m}$ alt.; ramos cilíndricos, estriados, tomentosos. Folhas simples, alternas, sésseis, lâmina 1-6,5 × 0,1-0,5 cm, linear-lanceolada; ápice acuminado, margem inteira ou levemente serreada, base truncada; ambas as faces escabras, estrigosotomentosas, glandulosas. Capítulos discóides, em corimbos terminais densos, pedúnculo até $3 \mathrm{~mm}$; invólucro campanulado, 4,5-6 × $3 \mathrm{~mm}$; brácteas involucrais livres, persistentes, 2-seriadas, ca. 10 , 4,5-5 × 1-2 mm, lanceoladas ou oblongas, tomentosas, glandulosas, esverdeadas ou púrpuras, ápice agudo ou obtuso, purpúreo, margem inteira, ciliada; receptáculo plano. Flores 5, perfeitas, lilases, corola tubulosa, tubo 2,5-3,5 mm, glabro, lobos glandulosos; anteras de base aguda, ápice ovado; ramos do estilete lineares, cilíndricos, apêndices conspícuos, papilosos. Cipselas obcônicas, 2-2,5 × $1 \mathrm{~mm}$, glabras, 5-costadas; pápus cerdoso, 1-seriado, cerdas alvas, 3-4 mm.

Material examinado: BRASIL. Minas Gerais: Uberlândia, Reserva Ecológica do Panga, 30-VII-1999, fl., bot., Araújo 2653 (HUFU); 19-XI-1999, fl., bot., Araújo 2918 (HUFU); 29-I-1999, fl., bot., Barbosa \& Amaral 1307 (HUFU); 30-IV-1999, fl., bot., Barbosa \& Faria 1994 (HUFU); 21-V-1999, fl., bot., Barbosa s.n. (HUFU20095); 10-XII-1993, fl., bot., Romero \& Arantes 568 (HUFU). 
Disynaphia senecionidea é conhecida apenas para o Brasil, nos estados de Mato Grosso, Minas Gerais, Paraná e Rio Grande do Sul. Esta espécie ocorre em campo sujo úmido e vereda na REP, podendo ser reconhecida pelas folhas alternas, capítulos com 5 flores e dispostos em corimbos densos terminais.

38. Elephantopus biflorus (Less.) Sch. Bip., Linnaea 20: 519.1847.

Subarbusto, 0,5-1 m alt.; ramos estriados, híspidotomentosos. Folhas simples, alternas, sésseis, lâmina 1-8 $\times 0,2-2 \mathrm{~cm}$, lanceolada a oblonga ou espatulada; ápice agudo a obtuso, margens crenadas, base amplexicaule; ambas as faces híspido-tomentosas, glandulosas. Capítulos discóides, em glomérulos, brácteas subinvolucrais foliáceas, lanceoladas a ovadas, híspido-tomentosas; invólucro cilíndrico, 7-8 × 1-1,5 mm; brácteas involucrais persistentes, 4-5-seriadas, 1,5-7 × 0,5-1 mm, lanceoladas, glabras, ápice purpúreo, acuminado, margens inteiras; receptáculo plano. Flores 2, perfeitas, púrpuras, corola tubulosa, tubo 3,5-4 mm, glabro ou glanduloso, lobos glabros; anteras de base sagitada, calcarada, ápice elíptico; ramos do estilete pilosos abaixo do ponto de bifurcação. Cipselas obcônicas, 1,5-3 × 0,2-0,9 mm, setoso-tomentosas; pápus cerdoso, 2-seriado, cerdas achatadas, série interna $4 \mathrm{~mm}$, série externa $1 \mathrm{~mm}$.

Material examinado: BRASIL. Minas Gerais: Uberlândia, Reserva Ecológica do Panga, 2-VI-2000, fl., fr., Araújo s.n. (HUFU23470); 30-IV-1999, fl., fr., Barbosa \& Faria 2019 (HUFU); 7-V-2007, fl., fr., Hattori 728 (HUFU).

Elephantopus biflorus ocorre apenas no Brasil, nos estados de Goiás, Minas Gerais, São Paulo e no Distrito Federal. Esta espécie ocorre em vereda na REP, podendo ser reconhecida pelas folhas com base amplexicaule, indumento híspido-tomentoso e capítulos em glomérulos axilares, com apenas 2 flores.

39. Elephantopus erectus Gleason, Phytologia 1: 40. 1933.

Subarbusto, ca. 1,7 m alt.; ramos cilíndricos, estriados, seríceo-tomentosos, prateados. Folhas simples, alternas, sésseis, lâmina 3-17 × 1-7 cm, ovada, elíptica a oblanceolada; ápice agudo a obtuso, margem levemente serrilhada, base truncada a atenuada; face adaxial estrigoso-tomentoso, face abaxial vilosotomentoso, prateado. Capítulos discóides, sésseis, em glomérulos axilares, série de brácteas subinvolucrais, lanceoladas, seríceo-tomentosas; invólucro cilíndrico, $11 \times 2,5 \mathrm{~mm}$; brácteas involucrais persistentes, 1-seriadas, 4, 9-10 × 1,5 mm, lanceoladas a linearlanceoladas, palhetes, glabras, ápice acuminado, seríceo; receptáculo plano. Flores 4, perfeitas, púrpuras, corola tubulosa, tubo $3 \mathrm{~mm}$, glabro, lobos glabros; anteras de base sagitada, calcarada, ápice lanceolado; ramos do estilete lineares, pilosos abaixo do ponto de bifurcação. Cipselas fusiformes, 5-6 $\times$ $1 \mathrm{~mm}$, seríceas; pápus cerdoso, 1-seriado, cerdas planas, 2-3 $\mathrm{mm}$.

Material examinado: BRASIL. Minas Gerais: Uberlândia, Reserva Ecológica do Panga, 27-IV-1992, bot., Barbosa 605 (HUFU); 22-V-1992, fl., fr., Araújo et al. 159 (HUFU, RB); 19-III-2007, fl., fr., Hattori \& Vargas 540 (HUFU).

Elephantopus erectus ocorre apenas no Brasil, nos estados de Goiás, Minas Gerais e São Paulo. Esta espécie ocorre em campo sujo e cerrado sentido restrito na REP. E. erectus pode ser reconhecida pelos capítulos em glomérulos axilares.

40. Elephantopus mollis Kunth, Nov. Gen. Sp. (folio ed.) 4: 20-21. 1820 [1818].

Erva, ca. 0,8 m alt.; ramos delgados, angulosos, estriados, seríceos. Folhas simples, alternas, rosuladas na base, sésseis, lâmina 4-16 × 1-8 cm, lanceolada a elíptica; ápice agudo a obtuso, margem crenada, base aguda a atenuada, semiamplexicaule; ambas as faces setosas, glandulosas. Capítulos discóides, em glomérulos terminais nos ramos, brácteas subinvolucrais foliáceas, ovadas a triangulares, seríceas, glandulosas; invólucro cilíndrico, 6-7 × $1,5 \mathrm{~mm}$; brácteas involucrais persistentes, 2-seriadas, 3-6 $\times 0,5-1,5 \mathrm{~mm}$, ovadas a lanceoladas, glabras, ápice acuminado, margem inteira; receptáculo plano. Flores 4, perfeitas, alvas, corola tubulosa, tubo $3,5 \mathrm{~mm}$, glabro, lobos glabros, anteras de base sagitada, calcarada, ápice lanceolado; ramos do estilete pilosos abaixo do ponto de bifurcação. Cipselas turbinadas, 2,5-3 $\times$ $0,8 \mathrm{~mm}$, glabras, multicostadas, ciliadas; pápus cerdoso, 1-seriado, cerdas filiformes, espessadas na base, palhetes, 3-3,5 $\mathrm{mm}$.

Material examinado: BRASIL. Minas Gerais: Uberlândia, Reserva Ecológica do Panga, 12-VII-1999, fr., Arantes 1012 (HUFU); 20-III-1987, fl., fr., Araújo s.n. (HUFU897); 19-III-2007, fl., fr., Hattori \& Vargas 545 (HUFU); 30-IV-1999, fr., Lemos s.n. (HUFU20657). 
Elephantopus mollis ocorre na Colômbia, Peru, Argentina, Uruguai e, no Brasil sendo citada para todos os estados. Esta espécie ocorre em borda de mata seca semidecídua, campo sujo, cerradão e vereda na REP. Pode ser reconhecida por possuir folhas rosuladas na base, ramos delgados, o que não ocorre em outras espécies do gênero existentes na REP.

\section{Elephantopus palustris Gardner, London J. Bot.} 5:237. 1846.

Erva, ca. 0,7 m alt.; ramos angulosos, estriados, glandulosos. Folhas alternas, sésseis, lâmina 4,5-15 $\times$ 0,2-0,7 cm, linear-lanceolada; ápice acuminado, margem serreada, base amplexicaule; ambas as faces setosas, glandulosas. Capítulos discóides, sésseis, em glomérulos formando cimeiras nos ramos, envolvidos por uma série de brácteas subinvolucrais foliáceas, conduplicadas, oval-lanceoladas; invólucro cilíndrico, $7-9 \times 2 \mathrm{~mm}$; brácteas involucrais persistentes, 3-seriadas, 3-9 × 1-2 mm, lanceoladas, glabras, ápice acuminado, margens serrilhadas; receptáculo plano. Flores 4, perfeitas, lilases, corola tubulosa, tubo $4 \mathrm{~mm}$, glabro, ápice 5-lobado, lobos glandulosos; anteras de base sagitada, calcarada, ápice oval-lanceolado; ramos do estilete pilosos abaixo do ponto de bifurcação. Cipselas turbinadas, glandulosas; pápus paleáceo, 1-seriado, 1,5 mm.

Material examinado: BRASIL. Minas Gerais: Uberlândia, Reserva Ecológica do Panga, 25-VI-1999, fl., fr., Faria s.n. (HUFU20453).

Elephantopus palustris ocorre no Brasil, nos estados do Piauí, Mato Grosso, Mato Grosso do Sul, Goiás, Minas Gerais, Paraná e no Distrito Federal. Esta espécie ocorre em vereda na REP. E. palustris se diferencia de outras espécies do gênero presentes na REP pelas folhas lineares e as brácteas subinvolucrais conduplicadas.

42. Emilia sonchifolia (L.) DC., Contr. Bot. India 24. 1834.

Erva, 1-1,2 m alt.; ramos estriados, setosos. Folhas simples, alternas, sésseis, lâmina 3,5-9,5 × 0,9-3 cm, lanceolada a auriculiforme; ápice acuminado a obtuso, margem serreada, base truncada a amplexicaule; ambas as faces glandulosas, setosas. Capítulos discóides, em panículas terminais, pedúnculo até $3 \mathrm{~mm}$; invólucro cilíndrico, 6-9 × 4-5 mm; brácteas involucrais 1-seriadas, conadas na base, 7-8 $\times 1$-2 mm, lineares, glabras, ápice agudo a acuminado, margem inteira; receptáculo plano. Flores ca. 50, perfeitas, róseas a vermelhas, corola tubulosa, tubo $8 \mathrm{~mm}$, glabro, lobos glabros; anteras de base obtusa, ápice lanceolado; ramos do estilete lanceolados, ápice truncado, penicelado. Cipselas cilíndricas, estrigosas, $2 \times 0,5 \mathrm{~mm}$; pápus cerdoso, 1-seriado, cerdas filiformes, alvas, até $5 \mathrm{~mm}$.

Material examinado: BRASIL. Minas Gerais: Uberlândia, Reserva Ecológica do Panga, 22-V-1992, fl., bot., Araújo et al. 143 (HUFU, UEC); 28-V-1999, fl., Lemos s.n. (HUFU20716).

Emilia sonchifolia ocorre nas Guianas e amplamente no Brasil com exceção da região Sul. Esta espécie ocorre em cerrado sentido restrito e vereda na REP. E. sonchifolia é facilmente conhecida pelas folhas com base amplexicaule e flores vermelhas.

43. Erechtites hieraciifolius (L.) Raf. ex DC., Prodr. 6:294. 1837 [1838].

Erva a subarbusto, 0,6-1 m alt.; ramos estriados, sulcados, setosos. Folhas simples, alternas, sésseis, lâmina 3-11 × 0,5-3,5 cm, lanceolada; ápice acuminado, margens pinatífidas, base truncada; ambas as faces setosas, glandulosas. Capítulos disciformes, em panículas terminais, pedúnculo até $4,5 \mathrm{~cm}$; invólucro cilíndrico, 9-12 × 4-7 mm, calículo presente; brácteas involucrais 1-seriadas, 7-10 × 0,6-1 mm, linearlanceoladas, setosas, glandulosas, ápice agudo, margem inteira, conadas na base; receptáculo côncavo. Flores marginais pistiladas, amarelas, numerosas, corola filiforme, tubo $7 \mathrm{~mm}$, glabro; ramos do estilete truncados, ápice penicelado. Cipselas fusiformes, 8-10-costada, $2 \times 0,5 \mathrm{~mm}$, costas serreadas; pápus cerdoso, 1 -seriado, cerdas filiformes, alvas, $6 \mathrm{~mm}$. Flores centrais perfeitas, amarelas, corola tubulosa, tubo $7 \mathrm{~mm}$, lobos papilosos; anteras de base aguda, ápice oblongo; ramos do estilete truncados, penicelados. Cipselas fusiformes, 10-costadas, 1,5 $\times$ $0,5 \mathrm{~mm}$, glabras; pápus cerdoso, 1 -seriado, cerdas filiformes, ca. $7 \mathrm{~mm}$.

Material examinado: BRASIL. Minas Gerais: Uberlândia, Reserva Ecológica do Panga, 19-XI-1999, fl., fr., Araújo 2915 (HUFU); 22-X-1999, fr., Araújo \& Amaral 2831 (HUFU); 24-IX-1998, fl., fr., Araújo s.n. (HUFU17996); 6-XI-1998, fl., fr., Barbosa \& Amaral s.n. (HUFU17831); 12-III-2007, fl., fr., Hattori \& Vargas 515 (HUFU).

Erechtites hieraciifolius ocorre amplamente na América do Sul e amplamente no Brasil, sendo citada 
para todas as regiões. Esta espécie ocorre em vereda na REP. E. hieraciifolius pode ser reconhecida pelas folhas pinatífidas e pela presença do calículo na base do invólucro e flores amarelas.

44. Eremanthus glomerulatus Less., Linnaea 4: 317. 1829.

Árvore, ca. 2,5 m alt.; ramos estriados, tomentosos. Folhas simples, alternas, sésseis, lâmina 2-9 × 1-3 cm, lanceolada a oval-lanceolada; ápice acuminado a agudo, margem inteira, levemente ondulada, base aguda a atenuada; face adaxial glabra, nervura tomentosa, face abaxial alvo-tomentosa. Capítulos discóides, em glomérulos envolvidos por uma série de brácteas foliáceas em comum, formando panículas terminais; invólucro obcônico, 3-4 × $2 \mathrm{~mm}$; brácteas involucrais persistentes, 4-seriadas, imbricadas, 1,5-3 × 0,2-1 mm, linear-lanceoladas a lanceoladas, lanosas no ápice das brácteas mais externas, ápice agudo a acuminado, margem serrilhada; receptáculo plano. Flor 1, perfeita, lilás, corola tubulosa, tubo $3 \mathrm{~mm}$, glabro, lobos glandulosos; anteras de base sagitada, calcarada, ápice lanceolado; ramos do estilete pilosos abaixo do ponto de bifurcação. Cipselas obcônicas, $2 \times 1 \mathrm{~mm}$, seríceas; pápus cerdoso, 3-seriado, cerdas 2-4 mm.

Material examinado: BRASIL. Minas Gerais: Uberlândia, Reserva Ecológica do Panga, 11-VII-1997, fr., Araújo \& Prado s.n. (HUFU17980); 7-V-2007, fl., fr., Hattori 734 (HUFU); 26-V-1997, fl., fr., Krauss 61 (HUFU).

Eremanthus glomerulatus ocorre somente no Brasil, no estado da Bahia, Goiás, Minas Gerais, São Paulo e no Distrito Federal. Esta espécie ocorre em cerrado aberto e transição cerrado sentido restritovereda na REP. E.glomerulatus é conhecida por ser uma espécie de hábito arbóreo, com os capítulos conados entre si em glomérulos no ápice dos ramos.

45. Gochnatia barrosii Cabrera, Notas Mus. La Plata, Bot. 15: 46. 1950.

Arbusto, ca. 1,5 m alt.; ramos angulosos, estriados, estrelado-tomentosos. Folhas simples, alternas, pecíolo até $1 \mathrm{~cm}$, lâmina $2-12,5 \times 0,7-7,5 \mathrm{~cm}$, ovada a ovallanceolada; ápice agudo ou obtuso, margem inteira, base arredondada; face adaxial estrelado-tomentosa, face abaxial estrelado-lanuginosa. Capítulos discóides, em panículas laxas, pedúnculo até $1 \mathrm{~cm}$; invólucro campanulado, 7-8 $\times 5 \mathrm{~mm}$; brácteas involucrais 6-seriadas, imbricadas, 40-50, 2-7 × 1-1,2 mm, ovadas a lanceoladas, setosas, creme, ápice agudo a acuminado, margem serrilhada, ciliada; receptáculo plano, glabro. Flores 15-20, perfeitas, creme, corola tubulosa, tubo $3 \mathrm{~mm}$, glabro, lobos glabros; anteras de base caudada, ápice lanceolado; ramos do estilete oblongos, glabros. Cipsela obcônica, 2-3 × 0,5-1 mm, vilosa, 5-costada; pápus cerdoso, 1-seriado, cerdas alvas, $6 \mathrm{~mm}$.

Material examinado: BRASIL. Minas Gerais: Uberlândia, Reserva Ecológica do Panga, 11-VII-1997, fl., fr., Araújo \& Mendes s.n. (HUFU17977); 20-IX-1998, fl., fr., Carvalho 70 (HUFU).

Gochnatia barrosii ocorre no Paraguai e no Brasil, nos estados do Maranhão, Mato Grosso, Mato Grosso do Sul, Goiás, Minas Gerais, São Paulo e Paraná. Esta espécie ocorre em transição cerrado sentido restrito-vereda na REP. G. barrosii é reconhecida pelos capítulos dispostos em panículas laxas, folhas, ramos, e brácteas involucrais tomentosas.

46. Heterocondylus grandis (Sch. Bip. ex Baker) R.M. King \& H. Rob., Phytologia 24: 390. 1972 $\equiv$ Eupatorium grande Sch. Bip. ex Baker, Fl. bras. 6(2):347. 1876.

Erva, 0,3-1 m alt.; ramos avermelhados, estriados, estrigosos. Folhas simples, opostas, pecíolo até $2 \mathrm{~mm}$, lâmina 0,5-3 ×0,2-1,1 cm, lanceolada a elíptica, ovallanceolada ou ovada; ápice agudo a obtuso ou arredondado, margem serreada ou crenada, levemente revoluta, base obtusa ou arredondada; face adaxial glabra a estrigosa, glandulosa ou não, face abaxial setosa, glandulosa. Capítulos discóides, solitários, pedúnculo 3,5 cm; invólucro campanulado, 7-13 $\times$ 7-13 mm; brácteas involucrais persistentes, livres, ca. 11, 2-3-seriadas, 8 -10 × 1,5-3 mm, $10 \times 1,5-2 \mathrm{~mm}$, elípticas a lanceoladas, glabras, ápice agudo ou obtuso, róseo, margem ciliada; receptáculo plano. Flores 30-60(120), perfeitas, róseas a lilases, corola tubulosa, tubo 6-7 mm, glabro, lobos glabros; anteras de base aguda ou arredondada, ápice elíptico; ramos do estilete lineares, apêndices conspícuos, papilosos. Cipselas fusiformes, $2 \times 0,5 \mathrm{~mm}$, glabras, 5-costadas; pápus cerdoso, 1-seriado, cerdas alvas, 5-6 mm.

Material examinado: BRASIL. Minas Gerais: Uberlândia, Reserva Ecológica do Panga, 21-I-2000, fl., fr., bot., Araújo 3027 (HUFU); 18-II-2000, fl., Araújo 3052 (HUFU); 28-IV-2000, fl., Barbosa 3552 (HUFU); 29-I-1999, fl., fr., Barbosa \& Amaral 1308 
(HUFU); 26-III-1999, fl., fr., Barbosa \& Araújo s.n. (HUFU19586); 30-IV-1999, fl., fr., Barbosa \& Faria 1988 (HUFU); 27-V-1994, fl., fr., bot., Nakajima et al. 346 (HUFU).

Heterocondylus grandis ocorre no Paraguai e no Brasil, nos estados de Goiás, Minas Gerais, Paraná, Rio Grande do Sul e no Distrito Federal. Esta espécie ocorre em transição cerrado sentido restrito-vereda e vereda na REP. $H$. grandis pode ser reconhecida pelos seus ramos avermelhados e brácteas involucrais amplas, de ápice róseo.

47. Ichthyothere mollis Baker, Fl. bras. 6(3): 156. 1884.

Erva com xilopódio, 20-50 cm alt.; ramos angulosos, estriados, tomentosos, com folhas atrofiadas na porção basal. Folhas simples, opostas, sésseis, lâmina 2,5-9 × 0,5-4 cm, linear-lanceolada a elíptica; ápice acuminado ou agudo a obtuso, margem inteira a levemente crenada ou serrilhada, base aguda ou atenuada, semi-amplexicaule; face adaxial esparsosetosa a tomentosa, face abaxial esparso-estrigosa a estrigosa. Capítulos disciformes, em corimbos terminais; invólucro globoso, 4-5 × 4-5 mm; brácteas involucrais 2-seriadas, 4-6 × 2-5 mm, ovadas a orbiculares, glabras, ápice agudo a obtuso, margem serrilhada; receptáculo cônico, páleas ovadas, $5 \times$ $3 \mathrm{~mm}$, glabras, ápice agudo, margem ciliada. Flores do raio 2, pistiladas, amarelas a creme, corola tubulosa, tubo $1 \mathrm{~mm}$, glabro; ramos do estilete lineares, glabros, apêndices inconspícuos. Cipsela elipsóide, $4 \times 2 \mathrm{~mm}$, glabra, ápice arredondado; pápus ausente. Flores do disco numerosas, estaminadas por aborto do gineceu, amarelas, corola tubulosa, tubo $2 \mathrm{~mm}$, glabro, lobos papilosos; anteras de base sagitada, ápice amploovado. Cipselas abortivas; pápus ausente.

Material examinado: BRASIL. Minas Gerais: Uberlândia, Reserva Ecológica do Panga, 2-X-1992, fl., fr., Araújo 300 (HUFU); 20-XI-1992, fl., fr., Araújo 399 (HUFU); 15-I-1992, fl., bot., Barbosa 515 (HUFU); 23-IX-1993, fl., fr., Barbosa 874 (HUFU); 4-IX-1994, fl., bot., Barbosa 911 (HUFU); 31-X-1986, fl., fr., Schiavini s.n. (HUFU764).

Ichthyothere mollis ocorre apenas no Brasil, possuindo ampla distribuição. Esta espécie ocorre em campo sujo seco e cerrado sentido restrito na REP. I. mollis é facilmente reconhecida pelas brácteas involucrais semelhantes a escamas de peixe, e os capítulos agrupados em 3 envolvidos por um invólucro comum.
48. Inulopsis camporum (Gardner) G.L. Nesom, Phytologia 76(2): 120. 1994 EAster camporum Gardner, London J. Bot. 7: 79. 1848.

Figura 4

Erva, $15-30 \mathrm{~cm}$ alt.; ramos cilíndricos cilíndricos, estriados, sulcados, híspidos ou tomentosos. Folhas simples, alternas, sésseis, lâmina 1-6,5 × 0,2-0,9 cm, lanceolada a oblanceolada; ápice agudo ou obtuso, margem denteada, base atenuada; ambas as faces tomentosas, glandulosas. Capítulos radiados, solitários escapo floral longo, até $15 \mathrm{~cm}$; invólucro campanulado, 7-10 × $10 \mathrm{~mm}$; brácteas involucrais 2-3-seriadas, 20-30, $6-9 \times 1-1,2 \mathrm{~mm}$, lanceoladas a linear-lanceoladas, setosas ou tomentosas, ápice agudo ou acuminado, margens serrilhadas; receptáculo plano, foveolado. Flores do raio 20-40, pistiladas, creme, corola liguliforme, tubo 4-4,5 mm, setoso, limbo 6-7 $\times$ 1,2-2,5 mm, glabro, ápice 2-dentado; ramos do estilete, lanceolados, glabros. Cipselas obcônicas, $3 \times 1 \mathrm{~mm}$, seríceas; pápus cerdoso, 1-seriado, cerdas alvas, 5-6 mm. Flores do disco 35-45, estaminadas creme, corola tubulosa, tubo $4-5 \times 1,5 \mathrm{~mm}$, setoso, lobos glabros; anteras de base aguda, ápice oval-lanceolado. Cipselas abortivas, glabras; pápus cerdoso, 1-seriado, cerdas alvas, 5-6 $\mathrm{mm}$.

Material examinado: BRASIL. Minas Gerais: Uberlândia, Reserva Ecológica do Panga, 23-IX-1992, fl., fr., Barbosa 380 (HUFU); 24-IX-1992, fl., fr., Araújo 285 (HUFU, UEC).

Inulopsis camporum ocorre na Bolívia e no Brasil, nos estados de Goiás, Mato Grosso, Minas Gerais, São Paulo e no Distrito Federal. Esta espécie ocorre em campo sujo seco após queimadas e em cerrado sentido restrito na REP. I. camporum é reconhecida pelas folhas alternas na base, e os capítulos dispostos em escapo floral longo.

49. Leptostelma maximum D. Don, Brit. Fl. Gard., ser. 2: 38. 1831.

Arbusto, ca. $3 \mathrm{~m}$ alt.; ramos sulcados, escabros, estrigosos. Folhas simples, alternas, sésseis, lâmina 2,5-8 $\times 0,2-2,2 \mathrm{~cm}$, linear-lanceolada a lanceolada; ápice acuminado, margem serreada, bulado-estrigosa, base amplexicaule, formando uma bainha; ambas as faces estrigosas. Capítulos radiados, em corimbos, pedúnculo até $10 \mathrm{~cm}$; invólucro amplo-campanulado, $9 \times 17 \mathrm{~mm}$; brácteas involucrais 2-seriadas, $8 \times 2 \mathrm{~mm}$, linear-lanceoladas, estrigosas, ápice acuminado, margem serreada, ciliada; receptáculo convexo. Flores 
do raio pistiladas, alvas, corola liguliforme, tubo $3 \mathrm{~mm}$, setoso, limbo $12 \times 1 \mathrm{~mm}$, ápice 2-3-dentado; ramos do estilete lineares, papilosos. Cipsela obcônica, glabra, $1 \times 0,4 \mathrm{~mm}, 3$-costada; pápus cerdoso, 1-seriado, cerdas $4,5 \mathrm{~mm}$. Flores do disco estaminadas por aborto do gineceu, amarelas, corola tubulosa, tubo $4 \mathrm{~mm}$, estrigoso, lobos glabros; anteras de base obtusa, ápice lanceolado. Cipselas abortivas, glandulosas, 2-costadas; pápus cerdoso, 1-seriado, cerdas alvas, ca. $5 \mathrm{~mm}$.

Material examinado: BRASIL. Minas Gerais:
Uberlândia, Reserva Ecológica do Panga, 24-IV-1992, fl., fr., bot., Araújo et al. 49 (HUFU); 25-III-1993, fl., fr., Araújo et al. 444 (HUFU, RB, UEC); 21-I-2000, fl., fr., Araújo 3010 (HUFU); 9-VIII-1999, fr., Barbosa \& Faria 2151 (HUFU); 26-II-2007, fl., bot., Hattori \& Vargas 519 (HUFU); 10-XII-1993, fl., bot., Romero \& Arantes 564 (HUFU); 7-IV-1995, fl., Romero et al. 2099 (HUFU).

Leptostelma maximum ocorre no Paraguai, Argentina e no Brasil, desde Mato Grosso, Goiás e

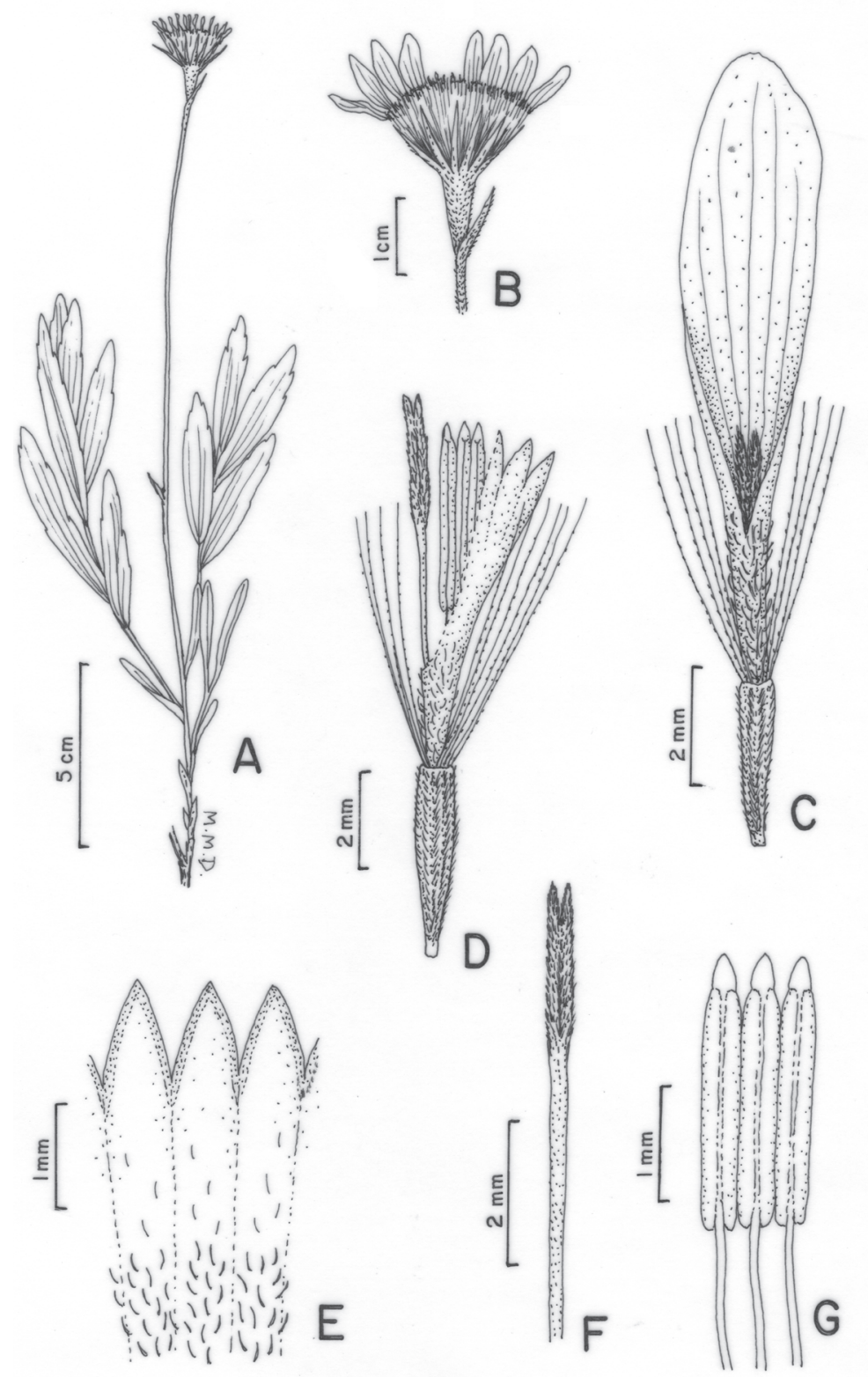

Figura 4. Inulopsis camporum (Gardner) G.L. Nesom. A) Hábito; B) Capítulo; C) Flor do raio; D) Flor do disco; E) Detalhe dos lobos da corola; F) Ramos do estilete; G) Anteras. (Araújo et al. 285, HUFU3361).

Figure 4. Inulopsis camporum (Gardner) G.L. Nesom. A) Habit; B) Head; C) Ray flower; D) Disc flower; E) Corola lobes in detail; F) Style branches; G) Anthers. (Araújo et al. 285, HUFU3361). 
Minas Gerais, Espírito Santo, Rio de Janeiro, São Paulo, Paraná, Santa Catarina e Rio Grande do Sul. Esta espécie ocorre em borda de mata de galeria, borda de mata semidecídua, borda de vereda, campo sujo úmido e vereda na REP. L. maximum pode ser reconhecida pelas folhas mais basais espatuladas, amplexicaules, formando uma bainha no caule.

50. Mikania cordifolia (L. f.) Willd., Sp. Pl. Editio quarta 3(3): 1746. 1803.

Erva volúvel; ramos angulosos, estriados, estrigoso-tomentosos. Folhas simples, opostas, pecíolo até 3,5 cm, lâmina 1-6 × 0,5-5 cm, cordada a ovada; ápice agudo ou obtuso, margem inteira ou levemente serreada, base obtusa ou cordada; face adaxial estrigosa, glandulosa, face abaxial tomentosa, glandulosa. Capítulos discóides, em corimbos densos, formando panículas ao longo dos ramos, pedúnculo $5 \mathrm{~mm}$; invólucro obcônico, 5-7 × 1,5-3 mm; brácteas involucrais 4, 5-7 × 1,5-2 mm, lanceoladas ou oblongas, estrigosas, glandulosas ou não, esverdeadas, ápice agudo ou acuminado, margem inteira, ciliada; receptáculo plano. Flores 4, perfeitas, creme ou alvas, corola tubulosa, tubo $3 \mathrm{~mm}$, glanduloso, lobos glabros; anteras de base aguda, ápice ovado; ramos do estilete lineares, apêndices conspícuos, papilosos. Cipselas obcônicas, $3 \times 0,6-1,2 \mathrm{~mm}$, estrigosas, 5-costadas, serreadas; pápus cerdoso, 1-seriado, ápice espessado, 4-5 mm.

Material examinado: BRASIL. Minas Gerais: Uberlândia, Reserva Ecológica do Panga, 3-IV-1987, fl., bot., Araújo s.n. (HUFU1015); 28-IV-2000, fl., fr., bot., Barbosa 3549 (HUFU); 26-V-2000, fl., fr., Barbosa 3378 (HUFU); 30-IV-1999, fl., fr., bot., Barbosa \& Faria 1989 (HUFU); 2-VI-2000, fr., Barbosa s.n. (HUFU23427).

Mikania cordifolia possui distribuição ampla na América do Sul. Esta espécie ocorre em mata de galeria, transição cerrado sentido restrito-vereda e vereda na REP. M. cordifolia é muito semelhante a M. micrantha pelas folhas cordiformes, mas difere desta por possuir capítulos maiores com flores maiores, além dos capítulos dispostos em corimbos densos.

51. Mikania micrantha Kunth, Nov. Gen. Sp. (folio ed.) 4: 105. 1820 [1818].

Erva volúvel; ramos cilíndricos, estriados, tomentosos. Folhas simples, opostas, pecíolo 1,5-2,5 cm, lâmina 2,5-4,5 ×2,5-3 cm, cordada; ápice acuminado, margem inteira a levemente dentada, base cordada; face adaxial estrigosa, face abaxial estrigosa, glandulosa. Capítulos discóides, subsésseis, formando panículas; invólucro cilíndrico, 4,5-5 × 1-1,5 mm; brácteas involucrais $4,4,5-5 \times 1 \mathrm{~mm}$, lanceoladas, esverdeadas, estrigosas, ápice agudo, margem ciliada; receptáculo plano. Flores 4, perfeitas, creme, corola tubulosa, tubo $2 \mathrm{~mm}$, glabro, lobos glandulosos no ápice; anteras de base obtusa, ápice lanceolado, ramos do estilete lineares, apêndices conspícuos, papilosos. Cipselas obcônicas, 1,5 × 0,4 mm, glandulosas, 5-costadas, serrilhadas; pápus cerdoso, 1-seriado, cerdas alvas, até $3,5 \mathrm{~mm}$.

Material examinado: BRASIL. Minas Gerais: Uberlândia, Reserva Ecológica do Panga, 7-V-2007, fl., bot., Hattori 739 (HUFU).

Mikania micrantha ocorre no Equador, Peru, Bolívia, Paraguai, Argentina e Uruguai, e no Brasil ocorre em todos os estados. Esta espécie ocorre em borda de campo sujo na REP. M. micrantha é reconhecida como distinta de $M$. cordifolia pelas características citadas anteriormente.

52. Mikania officinalis Mart, Reise Bras. 1:283. 1823.

Erva ereta, 0,3-0,5 m alt.; ramos angulosos, estriados, setosos. Folhas simples, opostas, sésseis, lâmina 0,7-4 × 0,5-4,5 cm, sagitiforme ou triangular; ápice agudo a acuminado, margens denteadas, levemente revolutas, base cordada a sagitada ou truncada; face adaxial estrigosa ou setosa, face abaxial estrigosa, glandulosa. Capítulos discóides, em umbelas formadas por panículas, pedúnculo $4 \mathrm{~mm}$; invólucro cilíndrico, $5-7 \times 1-2,5 \mathrm{~mm}$; brácteas involucrais $4,5-7 \times$ 0,7-1,5 mm, lanceoladas, estrigosas, glandulosas, ápice acuminado, margem inteira, ciliada; receptáculo plano. Flores 4, perfeitas, alvas a creme, corola tubulosa, tubo 3-4 mm, glabro, lobos setosos, glandulosos; anteras de base obtusa, ápice lanceolado; ramos do estilete lineares, apêndices conspícuos, papilosos. Cipselas obcônicas, 1,7-2,5 × 0,4-1 mm, glandulosas, 5-costadas, serrilhadas; pápus cerdoso, 1-seriado, cerdas alvas, 4-5 mm.

Material examinado: BRASIL. Minas Gerais: Uberlândia, Reserva Ecológica do Panga, 1-XII-1998, fl., fr., bot., Amaral s.n. (HUFU18334); 18-II-2000, fl., fr., Amaral \& Cardoso s.n. (HUFU22459); 22-X-1999, fl., fr., Araújo \& Amaral 2830 (HUFU); 19-XII-1986, fl., fr., bot., Araújo s.n. (HUFU826); 21-I-2000, bot., Araújo 3032 (HUFU); 17-XII-1999, fl., fr., bot., Barbosa 3080 (HUFU); 6-XI-1987, fl., fr., bot., 
Barbosa s.n. (HUFU1222); 19-II-1999, fl., fr., Barbosa \& Amaral 1310 (HUFU); 29-I-1999, fl., fr., Barbosa \& Amaral 1920 (HUFU); 13-XI-1992, fl., Nakajima \& Romero 37 (HUFU, RB).

Mikania officinalis ocorre no Brasil, nos estados do Tocantins, Bahia, Mato Grosso, Mato Grosso do Sul, Goiás, Minas Gerais, Rio de Janeiro, São Paulo, Paraná, Santa Catarina e no Distrito Federal. Esta espécie ocorre em campo sujo úmido e vereda na REP. M. officinalis é reconhecida dentre as espécies do gênero ocorrentes na REP por possuir hábito ereto e folhas sagitadas.

53. Mikania psilostachya DC., Prodr. 5: 190. 1836.

Erva volúvel; ramos estriados, hirsutos. Folhas simples, opostas, pecíolo até $12 \mathrm{~mm}$, lâmina 2-11 $\times$ $0,7-4,2 \mathrm{~cm}$, ovadas a oval-lanceoladas ou lanceoladas; ápice agudo ou acuminado, margem inteira ou serreada, levemente revoluta, base aguda a obtusa ou arredondada; face adaxial escabra, face abaxial tomentosa, glandulosa. Capítulos discóides, sésseis, em racemos; invólucro cilíndrico, 5-6 × 1,5-2,5 mm; brácteas involucrais 4, 4,5-6 × 0,8-1,5 mm, lanceoladas, setosas, glandulosas, ápice agudo ou obtuso, margem inteira, ciliada; receptáculo plano. Flores 4, perfeitas, alvas, corola tubulosa, tubo $5 \mathrm{~mm}$, glanduloso, lobos glandulosos; anteras de base obtusa, ápice ovado a lanceolado; ramos do estilete lineares, apêndices conspícuos, papilosos. Cipselas obcônicas, 3-3,5 $\times$ 0,4-0,7 mm, glandulosas, 5-costadas; pápus cerdoso, 1-seriado, cerdas palhete, $6-6,5 \mathrm{~mm}$.

Material examinado: BRASIL. Minas Gerais: Uberlândia, Reserva Ecológica do Panga, 27-II-1987, fl., fr., Araújo s.n. (HUFU846); 24-III-2000, fl., fr., Barbosa 3453 (HUFU); 23-IV-1999, fl., fr., Faria \& Araújo 2517 (HUFU); 12-III-2007, fl., fr., bot., Hattori 535 (HUFU).

Mikania psilostachya ocorre amplamente no Brasil, com exceção da região Sul. Esta espécie ocorre em mata seca semidecídua e vereda na REP. M. psilostachya pode ser reconhecida por possuir os capítulos dispostos em racemos e folhas com indumento escabro na face adaxial.

54. Picrosia longifolia D. Don, Trans. Linn. Soc. London 16: 184. 1830.

Erva latescente, ca. 0,6 m alt.; ramos angulosos, estriados, glabros. Folhas simples, alternas, sésseis, lâmina 9-22 × 1-1,5 cm, lanceolada a longo espatulada; ápice agudo, margem inteira, base atenuada, conduplicada; ambas as faces glabras. Capítulos ligulados, pedúnculo até $25 \mathrm{~cm}$, solitários; invólucro campanulado, 11-20 × 10-12 mm; brácteas involucrais 1-seriadas, 8, $17 \times 2-3 \mathrm{~mm}$, lanceoladas, glabras, ápice agudo, margem hialina, inteira; receptáculo plano. Flores ca. 80, perfeitas, amarelas, corola ligulada, tubo $8 \mathrm{~mm}$, lígula 13-15 × 1,5-2 mm, glabra; anteras de base sagitada calcarada, ápice ovado; estilete bilobado, glabro. Cipselas fusiformes, glabras, $3 \times 0,3 \mathrm{~mm}$, costadas; pápus cerdoso, 1-seriado, cerdas filiformes, $10 \mathrm{~mm}$.

Material examinado: BRASIL. Minas Gerais: Uberlândia, Reserva Ecológica do Panga, 16-X-1992, fl., bot., Araújo et al. 341 (HUFU, RB, ICN).

Picrosia longifolia ocorre na Argentina e no Brasil, nos estados de Minas Gerais, São Paulo, Paraná e Rio Grande do Sul. Esta espécie ocorre em campo sujo úmido na REP. P. longifolia é reconhecida por ser uma planta latescente, pelas folhas longo espatuladas, e os capítulos ligulados no ápice de um longo escapo floral.

55. Piptocarpha rotundifolia (Less.) Baker, Fl. bras. 6(2): 125, t. 28.1873.

Árvore, 3,5-4 m alt.; ramos angulosos, estriados, estrelado-tomentosos. Folhas simples, alternas, pecíolo 8-30 mm, lâmina 2-10,5 × 1,5-8,5 cm, elíptica a oblonga ou rotunda; ápice obtuso ou arredondado, margem inteira, ondulada, base obtusa ou truncada ou levemente cordada ou arredondada; face adaxial glabra, estrelado-tomentosa nas nervuras, face abaxial estrelado-tomentosa. Capítulos discóides, sésseis agrupados nas axilas das folhas; invólucro cilíndrico a fusiforme, $8-10 \times 3-4 \mathrm{~mm}$; brácteas involucrais caducas quando maduras, 5-6-seriadas, imbricadas, 30-35, 1-8 $\times 1$ 1-3 mm, ovadas a lanceoladas, glabras, ápice obtuso ou arredondado, glanduloso, tomentoso, margem inteira, ciliada; receptáculo cônico. Flores 4-5, perfeitas, creme, corola tubulosa, tubo 4-5 mm, glabro, lobos glandulosos; anteras de base sagitada, calcarada, ápice lanceolado; ramos do estilete lineares, pilosos abaixo do ponto de bifurcação. Cipsela obcônica, $3 \times$ 1-1,5 mm, glabra, 8-costada; pápus cerdoso, cerdas palhete, série interna 6-7 mm, série externa ca. $3 \mathrm{~mm}$.

Material examinado: BRASIL. Minas Gerais: Uberlândia, Reserva Ecológica do Panga, 29-V-1992, fl., fr., Araújo et al. 198 (HUFU, UEC); 16-I-1987, fl., fr., Araújo s.n. (HUFU800); 7-I-1989, fl., fr., 
Martins 37 (HUFU); 19-I-1993, fl., fr., Melo et al. 31 (HUFU, RB, UEC).

Piptocarpha rotundifolia ocorre apenas no Brasil, nos estados de Rondônia, Tocantins, Maranhão, Bahia, Mato Grosso, Mato Grosso do Sul, Goiás, Minas Gerais, São Paulo e no Distrito Federal. Esta espécie ocorre em cerrado sentido-restrito, cerradão e transição cerrado sentido restrito-vereda na REP. P. rotundifolia é facilmente reconhecida pelo hábito arbóreo, folhas discolores e os capítulos cilíndricos agrupados e dispostos nas axilas das folhas.

56. Podocoma bellidifolia Baker, Fl. bras. 6(3): 16. 1882.

Erva, ca. 0,5 m alt.; ramos angulosos, sulcados, glabros. Folhas simples, alternas, sésseis, lâmina 2-7,5 × 0,2-2,6 cm, lanceolada, ápice agudo ou acuminado, margem inteira, ciliada, base amplexicaule; ambas as faces glabras. Capítulos disciformes, solitários, pedúnculo até $4 \mathrm{~cm}$; invólucro campanulado, 6-7 $\times$ $10 \mathrm{~mm}$; brácteas involucrais 2 -seriadas, livres, ca. 20-28, 5-7 × 1, linear-lanceoladas, glabras, ápice acuminado, margem serrilhada; receptáculo convexo. Flores marginais ca. 25, pistiladas, corola filiforme, tubo $4 \mathrm{~mm}$, estrigoso, ápice 3-4-lobado, lobos papilosos; ramos do estilete lanceolados, glabros. Cipselas fusiformes, 3,5 $\times 0,7 \mathrm{~mm}$, seríceas, 5-costadas, costas ciliadas; pápus cerdoso, 1-seriado, cerdas alvas, 3-5 mm. Flores centrais ca. 70, perfeitas, corola tubulosa, tubo $4 \mathrm{~mm}$, glabro, lobos glabros; anteras de base aguda, ápice lanceolado; ramos do estilete oblongos. Cipsela fusiforme, $2 \times 0,8 \mathrm{~mm}$, serícea, 5-costada, ciliada; pápus cerdoso, 1-seriado, cerdas alvas, ca. $4 \mathrm{~mm}$.

Material examinado: BRASIL. Minas Gerais: Uberlândia, Reserva Ecológica do Panga, 29-IX-1992, fl., fr., Barbosa 873 (HUFU).

Podocoma bellidifolia ocorre no Paraguai, norte da Argentina, e região central do Brasil, nos estados de Goiás, Minas Gerais, São Paulo, Paraná, Rio Grande do Sul e no Distrito Federal. Esta espécie ocorre em campo sujo seco na REP. $P$. bellidifolia pode ser reconhecida pelas folhas com duas nervuras laterais saindo próximas a nervura central.

57. Praxelis basifolia (Malme) R.M. King \& H. Rob., Phytologia 20: 194. 1970 E Eupatorium basifolium Malme, Ark. Bot. 24a (8): 30. 1932.

Erva, 0,2-0,3 $\mathrm{m}$ alt.; ramos estriados, glabros ou setosos. Folhas rosuladas na base, opostas na parte superior do ramo, sésseis, lâmina 1-4,5 × 0,2-1 cm, lanceolada a oblanceolada; ápice acuminado a agudo ou obtuso, margem inteira a serreada, base aguda ou atenuada; ambas as faces esparso-setosas. Capítulos discóides, solitários, pedúnculo até $10,5 \mathrm{~cm}$; invólucro campanulado, 6-7 × 3-6 mm; brácteas involucrais caducas, 3-seriadas, 3-6 × 1-2 mm, oval-lanceoladas a lanceoladas, glabras, ápice acuminado a obtuso, purpúreo, margem inteira ou serrilhada; receptáculo cônico. Flores 45-55, perfeitas, púrpuras, corola tubulosa, tubo 2,5-4 mm, glabro; anteras de base aguda ou obtusa, ápice ovado; ramos do estilete clavelados, apêndices conspícuos, papilosos. Cipsela fusiforme, 1,5-2 × 0,6-0,7 mm, comprimida, 3-5-costada, serrilhada, ápice setoso; pápus cerdoso, 1-seriado, cerdas com ápice purpúreo, $3,5 \mathrm{~mm}$.

Material examinado: BRASIL. Minas Gerais: Uberlândia, Reserva Ecológica do Panga, 26-VI-1992, fl., bot., Araújo et al. 229 (HUFU); 11-IX-1998, fl., bot., Barbosa 1227 (HUFU); 22-XII-1997, fl., bot., Markstein et al. 31 (HUFU); 13-XI-1992, fl., bot., Nakajima \& Romero 49 (HUFU, RB).

Praxelis basifolia ocorre no Brasil, nos estados do Mato Grosso e Minas Gerais. Esta espécie ocorre em campo sujo úmido e vereda na REP. P. basifolia é facilmente reconhecida dentre as espécies pertencentes a este gênero encontradas na REP pelas suas folhas rosuladas na base e capítulo mais robusto.

58. Praxelis clematidea (Griseb.) R.M. King \& H. Rob., Phytologia 20(3): 194. 1970 三 Eupatorium clematideum Griseb., Jahresber. Pollichia 22-24: 258. 1866.

Erva, ca. 0,6 m alt.; ramos estriados, setosos. Folhas simples, opostas, sésseis, lâmina 1,5-3 × 0,5-1 cm, lanceolada; ápice agudo ou acuminado, margem serreada, base aguda; face adaxial estrigosa, face abaxial setosa. Capítulos discóides, em corimbos terminais, pedúnculo até $3 \mathrm{~cm}$; invólucro campanulado, 6-7 $\times 5 \mathrm{~mm}$; brácteas involucrais caducas, 3-4-seriadas, ca. 20, 3,5-7 × 1-1,2 mm, ovadas a lanceoladas, glabras, ápice acuminado, esverdeado, margem inteira, ciliada; receptáculo cônico. Flores ca. 40, perfeitas, lilases, corola tubulosa, tubo $3,5 \mathrm{~mm}$, glabro, lobos papilosos; anteras de base aguda, ápice lanceolado; ramos do estilete espatulados, apêndices conspícuos, papilosos. Cipsela obcônica, $2 \times 0,7 \mathrm{~mm}$, setosa, 5-costada, ciliada; pápus cerdoso, 1-seriado, cerdas alvas, ca. $4 \mathrm{~mm}$. 
Material examinado: BRASIL. Minas Gerais: Uberlândia, Reserva Ecológica do Panga, 22-I-1999, fl., fr., Lemos s.n. (HUFU20393).

Praxelis clematidea ocorre da Bolívia, Paraguai, Argentina e amplamente no Brasil. Esta espécie ocorre em vereda na REP. $P$. clematidea é facilmente reconhecível pelas folhas ovadas e os capítulos agrupados em corimbos terminais.

59. Praxelis grandiflora (DC.) Sch. Bip., Jahresber. Pollichia 22-24:254. 1866 Eupatorium variegatum Malme, Kongl. Svenska Vetenskapsakad Handl. ser. 3 12(2): 46. 1933.

Subarbusto, ca. de 0,7-1,5 m alt.; ramos estriados, setosos ou híspidos. Folhas simples, opostas, sésseis, lâmina 1,5-7 × 0,2-2 cm, lanceolada a linear-lanceolada; ápice acuminado ou agudo, margem serreada, levemente revoluta, base acuminada ou aguda; ambas as faces híspidas. Capítulos discóides, em panículas longas, terminais, pedúnculo até $8,5 \mathrm{~cm}$; invólucro campanulado, 7-8 × 4-7 mm; brácteas involucrais caducas, 3-4-seriadas, ca. de 23, 4,5-7,5 × 1-2,5 mm, ovadas a oblanceoladas, glabras, nervuras estriadas, ápice acuminado a arredondado, esverdeado, fimbriado, margem inteira; receptáculo cônico. Flores ca. de 60-65, perfeitas, alvas, corola tubulosa, tubo $4-5 \mathrm{~mm}$, glabro, lobos papilosos; anteras de base arredondada, ápice oval-lanceolado; ramos do estilete lineares, apêndices conspícuos, papilosos. Cipsela fusiforme, $2 \times 0,9-1 \mathrm{~mm}$, setosa no ápice, 3-4-costada, serrilhada; pápus cerdoso, 1-seriado, cerdas palhete, $5-5,5 \mathrm{~mm}$.

Material examinado: BRASIL. Minas Gerais: Uberlândia, Reserva Ecológica do Panga, 3-IV-1987, fl., fr., Araújo s.n. (HUFU974, HEPH); 19-III-2007, fl., bot., Hattori \& Vargas 547 (HUFU); 11-III-1994, fl., fr., Nakajima \& Romero 209 (HUFU).

Praxelis grandiflora ocorre apenas no Brasil, nos estados do Maranhão, Mato Grosso, Mato Grosso do Sul, Goiás, Minas Gerais, São Paulo, Paraná e no Distrito Federal. Esta espécie ocorre em campo sujo seco e transição cerrado sentido restrito-vereda na REP. P. grandiflora pode ser confundida com P. kleinioides pelo formato da folha, invólucro, mas difere desta por possuir porte maior com mais ramificações, brácteas involucrais com ápice esverdeado e flores alvas, enquanto $P$. kleinioides apresenta hábito herbáceo, com ápice das brácteas involucrais púrpuras e flores lilases.
60. Praxelis kleinioides (Kunth.) Sch. Bip., Jahresber. Pollichia 22-24: 254. 1866 E Eupatorium kleinioides Kunth., Nov. Gen. Sp. (folio ed.) 4:94. 1820 [1818].

Erva, 0,5-0,7 m alt.; ramos estriados, setosos ou esparso-setosos. Folhas simples, opostas, sésseis, lâmina 0,7-5 × 0,1-1 cm, linear-lanceolada a lanceolada; ápice acuminado ou agudo, margem inteira ou serreada, base aguda a acuminada ou atenuada; ambas as faces glabras a esparso-setosas, glandulosas. Capítulos discóides, solitários, pedúnculo até $30 \mathrm{~cm}$; invólucro campanulado, 7-8 × 3-8 mm; brácteas involucrais caducas, ca. 20, 3-4-seriadas, 2-6,5 × 1-2 mm, oblongas a ovadas ou ovallanceoladas, glabras, ápice acuminado ou agudo a obtuso, purpúreo, margem inteira; receptáculo cônico. Flores 60-70, perfeitas, alvas a liláses, corola tubulosa, tubo 3,5 mm, glabro, lobos papilosos; anteras de base obtusa, ápice oval-lanceolado; ramos do estilete lineares, apêndices conspícuos, papilosos. Cipsela obcônica, 1,5-2 × 0,2-0,6 mm, estrigosa, 5-costada, serrilhada; pápus cerdoso, 1-seriado, cerdas alaranjadas, 3,5-4,5 $\mathrm{mm}$.

Material examinado: BRASIL. Minas Gerais: Uberlândia, Reserva Ecológica do Panga, 26-VI-1992, fl., fr., Araújo et al. 228 (HUFU); 22-X-1999, fl. Araújo \& Amaral 2832 (HUFU); 11-IX-1998, fl., bot., Barbosa 128 (HUFU); 30-VII-1999, fl., fr., bot., Barbosa \& Mendes 2082 (HUFU); 21-I-2000, fl., Mendes s.n. (HUFU22280).

Praxelis kleinioides ocorre na América tropical e subtropical até o Norte da Argentina e no Brasil, em todas as regiões geográficas. Esta espécie ocorre em campo sujo úmido e vereda na REP. P. kleinioides é muito parecida com $P$. grandiflora, mas difere desta por possuir um porte herbáceo, brácteas involucrais com ápice purpúreo e flores lilases, enquanto P. grandiflora possui hábito subarbustivo, ápice das brácteas involucrais esverdeadas e corola alva.

61. Pterocaulon alopecuroides (Lam.) DC., Prodr. 5: 454. 1836.

Erva, ca. 0,7 m alt.; ramos estriados, tomentosos, com alas de $2 \mathrm{~mm}$ larg. Folhas simples, alternas, sésseis, lâmina 1,3-9 ×0,4-2,4 cm, elíptica a lanceolada; ápice agudo a obtuso, margem serreada, base decorrente no ramo; face adaxial aracnóide a glabrescente, face abaxial tomentosa. Capítulos disciformes, sésseis, em 
glomérulos congestos formando espigas terminais; invólucro campanulado, $4 \times 4 \mathrm{~mm}$; brácteas involucrais 3-4-seriadas, ca. 40, 3,5-5,5 × 0,5-0,7 mm, lanceoladas a linear-lanceoladas, lanosas, ápice acuminado, margem inteira, ciliada; receptáculo plano. Flores marginais ca. 35, pistiladas, creme, corola filiforme, tubo $5 \mathrm{~mm}$, glabro; ramos do estilete lineares. Cipsela fusiforme, $1 \times 0,2 \mathrm{~mm}$, estrigosa, glandulosa; pápus cerdoso, 1-seriado, cerdas alvas. 4-6 mm. Flores centrais 2, perfeitas, creme, corola tubulosa, tubo $4 \mathrm{~mm}$, glabro, lobos glandulosos; anteras de base caudada, ápice elíptico; ramos do estilete lanceolados, glabros abaixo do ponto de bifurcação. Cipsela obcônica, $1 \times$ $0,2 \mathrm{~mm}$, estrigosa, glandulosa; pápus cerdoso, 1 -seriado, cerdas alvas, 5-5,5 $\mathrm{mm}$.

Material examinado: BRASIL. Minas Gerais: Uberlândia, Reserva Ecológica do Panga, 15-II-1995, fl., fr., Barbosa 938 (HUFU).

Pterocaulon alopecuroides ocorre amplamente na América do Sul. Esta espécie ocorre em campo sujo seco na REP. P. alopecuroides pode ser reconhecida pelos capítulos dispostos em glomérulos congestos formando espigas longas. É confundida com $P$. lanatum, mas difere desta por possuir indumento aracnóide a glabrescente na face adaxial da folha, enquanto $P$. lanatum possui indumento híspidotomentoso.

62. Pterocaulon lanatum Kuntze, Revis. Gen. Pl. 3(2): 169. 1898.

Erva, ca. 0,6 m alt.; ramos estriados, lanosos, alados, alas até $2 \mathrm{~mm}$ larg. Folhas simples, alternas, sésseis, lâmina 2-10 × 0,4-3,3 cm, lanceolada; ápice acuminado a agudo, margem serreada, base aguda, decorrente no ramo; face adaxial híspido-tomentoso, nervuras lanosas, face abaxial lanosa. Capítulos disciformes, sésseis em glomérulos congestos formando espigas terminais; invólucro campanulado, $6 \times 5 \mathrm{~mm}$; brácteas involucrais 5-seriadas, ca. 50, 4-7 $\times$ 0,8-1 mm, lanceoladas a linear-lanceoladas, lanosas a glabrescentes, ápice acuminado, margem serrilhada, ciliada; receptáculo plano. Flores marginais ca. 75, pistiladas, creme, corola filiforme, tubo $5,5 \mathrm{~mm}$, glabro, ápice 3-4-dentado; ramos do estilete lineares, glabros. Cipsela cilíndrica, $1 \times 0,2 \mathrm{~mm}$, setosa, glandulosa; pápus cerdoso, 1-seriado, cerdas filiformes, alvas, 4-5,5 mm. Flores centrais 2, perfeitas, creme, corola tubulosa, tubo $4 \mathrm{~mm}$, glabro, lobos glandulosos, setosos; anteras de base caudada, ápice elíptico; ramos do estilete lanceolados, pilosos, glabros abaixo do ponto de bifurcação. Cipsela obcônica, $1 \times 0,2 \mathrm{~mm}$, serícea; pápus cerdoso, 1-seriado, cerdas ca. $4,5 \mathrm{~mm}$.

Material examinado: BRASIL. Minas Gerais: Uberlândia, Reserva Ecológica do Panga, 10-IV-1992, fl., fr., Araújo 31 (HUFU, RB).

Pterocaulon lanatum ocorre na Bolívia, Paraguai, Argentina e no Brasil, nos estados do Mato Grosso, Mato Grosso do Sul, Goiás, Minas Gerais, São Paulo, Paraná e no Distrito Federal. Esta espécie ocorre em campo sujo seco na REP. P. lanatum é semelhante a $P$. alopecuroides, e as características que diferem as duas espécies já foram mostradas anteriormente.

63. Pterocaulon rugosum (Vahl) Malme, Bih. Kongl. Svenska Vetensk.-Akad. Handl. 27(III-12): 16. 1901.

Subarbusto, ca. 1,2 m alt.; ramos cilíndricos, lanuginosos, alados. Folhas simples, alternas, sésseis, lâmina 2-5 × 0,7-1,5 cm, elíptica a lanceolada; ápice agudo a acuminado, margem serrilhada, base decorrente no ramo formando as alas do caule, alas ca. de $2 \mathrm{~mm}$ largura; face adaxial glabra a tomentosa, face abaxial densamente lanuginosa. Capítulos disciformes, sésseis, em glomérulos terminais; invólucro campanulado, $7 \times 5 \mathrm{~mm}$; brácteas involucrais 5-6-seriadas, 2-5 × 0,7 mm, ovallanceoladas a linear-lanceoladas, densamente lanuginosas, ápice agudo a acuminado. Flores marginais ca. 30 , pistiladas, creme, corola filiforme, tubo $8 \mathrm{~mm}$, glabro, ápice 3-dentado; ramos do estilete lineares, glabros. Cipsela fusiforme, 1,5 ×0,5 mm, vilosa, glandulosa; pápus cerdoso, 1 -seriado, cerdas creme, mm. Flor central 1, perfeita, corola tubulosa, tubo $5 \mathrm{~mm}$, esparso-setoso, lobos glandulosos; anteras de base acuminada, caudada, ápice ovado, ramos do estilete lanceolados, estrigosos, glabros abaixo do ponto de bifurcação. Cipsela cilíndrica; pápus cerdoso, 1-seriado, cerdas ca. $8 \mathrm{~mm}$.

Material examinado: BRASIL. Minas Gerais: Uberlândia, Reserva Ecológica do Panga, 19-III-2007, fl., fr., Hattori \& Vargas 538 (HUFU).

Pterocaulon rugosum ocorre na Venezuela, Colômbia, Paraguai, norte da Argentina e no Brasil, nos estados de Goiás, Minas Gerais, Rio de Janeiro, São Paulo, Paraná, Santa Catarina e no Distrito Federal. Esta espécie ocorre em campo sujo seco na REP. P. rugosum difere bastante das demais espécies 
do gênero ocorrentes na REP por possuir os capítulos dispostos em glomérulos terminais nos ramos e folhas com dimensões menores do que em $P$. alopecuroides e P. lanatum.

64. Raulinoreitzia crenulata (Spreng.) R.M. King \& H. Rob., Phytologia 22(2): 114. 1971 $\equiv$ Eupatorium crenulatum Spreng. ex Hieron., Bot. Jahrb. Syst. 22: 776. 1897.

Subarbusto a arbusto, ca. 1,5-3 m alt.; ramos angulosos, estriados, glabros. Folhas simples, opostas, pecíolo até $12 \mathrm{~mm}$, lâmina 1-8,5 ×0,2-3,7 cm, elíptica a obovada; ápice obtuso a arrendondado ou agudo a acuminado; margem serreada ou crenada, base aguda ou acuminada; ambas as faces glandulosas. Capítulos discóides, sésseis, em espigas, formando panículas; invólucro cilíndrico, 5-6 × 2-3 mm; brácteas involucrais persistentes, livres, 4-seriadas, 1-6 × 0,6-1,5 mm, ovadas a lanceoladas, glabras, ápice obtuso a arredondado, glanduloso, margem serrilhada, ciliada; receptáculo levemente convexo. Flores 5, perfeitas, alvas, corola tubulosa, tubo 2,5-3,5 mm, glanduloso, ápice 5-lobado, lobos glandulosos; anteras de base aguda, ápice ovado; ramos do estilete lineares, apêndices conspícuos, papilosos. Cipsela obcônica, 1,5-2 × 0,5-0,7 mm, glabra, 5-costada; pápus cerdoso, 1-seriado, cerdas alvas, $3,5-4 \mathrm{~mm}$.

Material examinado: BRASIL. Minas Gerais: Uberlândia, Reserva Ecológica do Panga, 19-IV-1994, fl., fr., Arantes \& Marra 176 (HUFU); 26-V-2000, bot., fl., fr., Araújo 3250 (HUFU); 3-IV-1992, bot., fl., fr., Araújo et al. 139 (HUFU, RB); 10-III-1997, bot., fl., fr., Araújo s.n. (HUFU17989); 12-III-1999, fl., fr., Araújo s.n. (HUFU19492); 11-V-1999, fl., fr., Araújo s.n. (HUFU20060); 24-III-2000, bot., fl., fr., Barbosa 3455 (HUFU); 13-III-1994, bot., fl., fr., Nakajima \& Romero 208 (HUFU).

Raulinoreitzia crenulata ocorre no Peru, Bolívia, Paraguai, Argentina e Brasil, nos estados do Piauí, Mato Grosso, Mato Grosso do Sul, Goiás, Minas Gerais, São Paulo, Paraná, Santa Catarina, Rio Grande do Sul e no Distrito Federal. Esta espécie ocorre em campo sujo úmido, transição cerrado sentido restrito-vereda e vereda na REP. $R$. crenulata é muito semelhante a $R$. tremula, pelos capítulos dispostos em espigas formando panículas, mas difere desta pelo formato do limbo foliar, sendo mais ovada a elíptica em $R$. crenulata e mais linear em $R$. tremula.
65. Raulinoreitzia tremula (Hook. \& Arn.) R.M. King \& H. Rob., Phytologia 22(2): 114. 1971 $\equiv$ Eupatorium tremulum Hook. \& Arn., Compan. Bot. Mag. 1: 241. 1835.

Subarbusto, ca. 1,4 m alt.; ramos estriados, glabros. Folhas simples, opostas, pecíolo até $5 \mathrm{~mm}$, lâmina 2,5-5,5 × 0,6-1,6 cm, linear-lanceolada; ápice agudo a acuminado, margem serrilhada, base atenuada; ambas as faces glandulosas. Capítulos discóides, sésseis, em espigas formando panículas; invólucro cilíndrico, $6 \times 2 \mathrm{~mm}$; brácteas involucrais persistentes, livres, 3-seriadas, ca. 12, 1,5-6 $\times$ 0,8-1 mm, ovadas a lanceoladas, glabras, ápice agudo a obtuso, margem serrilhada, ciliada; receptáculo levemente convexo. Flores 5, perfeitas, creme, corola tubulosa, tubo 3,5 mm, glanduloso, lobos glandulosos; anteras de base auriculada, ápice oval-lanceolado; ramos do estilete lineares, apêndices conspícuos, papilosos. Cipsela obcônica, 1,5 × 0,5 mm, glabra, 5-costada; pápus cerdoso, 1-seriado, cerdas alvas, ca. $4 \mathrm{~mm}$, ápice espessado.

Material examinado: BRASIL. Minas Gerais: Uberlândia, Reserva Ecológica do Panga, 19-II-1999, bot., Araújo 2687 (HUFU); 3-III-2000, fl., fr., Araújo \& Mendes s.n. (HUFU22584); 30-IV-1999, fl., fr., Barbosa \& Faria 1996 (HUFU).

Raulinoreitzia tremula ocorre na Argentina e no Brasil, nos estados de Mato Grosso do Sul, Goiás, Minas Gerais, São Paulo, Paraná, Santa Catarina, Rio Grande do Sul e no Distrito Federal. Esta espécie ocorre em vereda na REP. $R$. tremula é muito semelhante a $R$. crenulata, mas difere desta pelos motivos já apontados anteriormente.

66. Riencourtia oblongifolia Gardner, Hooker's J. Bot. Kew Gard. Misc. 7: 287. 1848.

Erva, ca. 0,5 m alt.; ramos estriados, estrigosos. Folhas simples, opostas, pecíolo 2-3 mm, lâmina 2,5-6 $\times 0,6-2,5 \mathrm{~cm}$, elípticas a lanceoladas, nervuras acródromas basais; ápice obtuso a acuminado, margem denteadas base aguda ou obtusa, ambas as faces escabras. Capítulos disciformes, sésseis, em glomérulos terminais, envoltos por um invólucro comum; invólucro campanulado, 5,5 ×4 mm; brácteas involucrais 1-seriadas, 4, 5,5 × 2-3 mm, elípticas a obovadas, glabras, ápice obtuso ou arredondado, ápice setoso, margens inteiras; receptáculo plano. Flores marginais 8, estaminadas, amarelas ou alaranjadas, corola tubulosa, tubo $2 \mathrm{~mm}$, glabro, lobos híspidos; 
anteras de base aguda, ápice ovado; estilete indiviso, piloso. Cipsela abortiva; pápus ausente. Flor central 1, pistilada, amarela, corola filiforme, tubo $3 \mathrm{~mm}$, glabro, lobos híspidos; ramos do estilete lineares, glabros, apêndices inconspícuos. Cipsela elipsóide, $2 \times 1 \mathrm{~mm}$, ápice híspido; pápus ausente.

Material examinado: BRASIL. Minas Gerais: Uberlândia, Reserva Ecológica do Panga, 16-I-1987, fl., fr., bot., Araújo s.n. (HUFU940); 19-I-1993, fl., bot., Melo et al. 33 (HUFU, RB, UEC).

Riencourtia oblongifolia ocorre na Argentina e no Brasil, nos estados do Tocantins, Maranhão, Mato Grosso, Mato Grosso do Sul, Goiás, Minas Gerais, São Paulo e no Distrito Federal. Esta espécie ocorre em campo sujo e cerradão na REP. $R$. oblongifolia pode ser reconhecida pelas folhas lanceoladas e com nervuras próximas a margem, e capítulos pequenos agrupados no ápice dos ramos.

67. Spilanthes nervosa Chodat, Bull. Herb. Boissier, sér. 2: 724. 1903.

Erva, ca. 0,8 m alt.; ramos estriados, sulcados, hirsutos. Folhas simples, opostas, sésseis, lâmina 3,5-8,5 × 0,5-2 cm, lanceolada a obovada; ápice acuminado a agudo ou arredondado, margem inteira, base aguda; face adaxial híspida, face abaxial setosa, nervuras hirsutas. Capítulos discóides, solitários, pedúnculo 12-30 cm; invólucro campanulado, 7-10 $\times$ $10 \mathrm{~mm}$; brácteas involucrais 2-seriadas, $5-7 \times 1,2 \mathrm{~mm}$, lanceoladas, glabras, ápice acuminado, margem inteira, ciliada; receptáculo cônico, páleas oblongas, conduplicadas, estriadas, glabras, $5 \times 1,4 \mathrm{~mm}$. Flores perfeitas, amareladas, corola tubulosa, tubo $1,5 \mathrm{~mm}$, glabro, lobos papilosos; anteras de base aguda, ápice lanceolado; ramos do estilete oblongos, pilosos, apêndices inconspícuos. Cipsela obovóide, comprimida, $3 \times 2 \mathrm{~mm}, 4$-costada, bordos laterais denso-ciliados; pápus 2-aristado, $1 \mathrm{~mm}$.

Material examinado: BRASIL. Minas Gerais: Uberlândia, Reserva Ecológica do Panga, 30-X-1993, fl., fr., Barbosa 704 (HUFU); 20-IX-1992, fl., fr., Barbosa 777 (HUFU); 23-IX-1993, fl., fr., Barbosa 875 (HUFU); 6-XI-1987, fl., fr., Barbosa et al. s.n. (HUFU1231).

Spilanthes nervosa ocorre na Venezuela, Colômbia, Bolívia, Paraguai e Brasil, nos estados de Mato Grosso, Mato Grosso do Sul, Goiás, Minas Gerais e no Distrito Federal. Esta espécie ocorre em campo sujo seco pós-fogo na REP. S. nervosa pode ser reconhecida pelos capítulos alvos, discóides e o receptáculo cônico, que caracteriza a posição das flores em um plano mais superior a partir do centro do receptáculo.

68. Stevia collina Gardner, London J. Bot. 5: 458. 1846.

Erva a subarbusto, ca. 0,9 m alt.; ramos estriados, hirsutos. Folhas simples, opostas, sésseis, lâmina 1-4 × 0,1-1 cm, lanceolada a oblanceolada; ápice agudo a obtuso, margem serrilhada da porção mediana até o ápice, base atenuada; face adaxial estrigosa ou tomentosa, glandulosa ou não, face abaxial tomentosa, glandulosa ou não. Capítulos discóides, em panículas terminais, pedúnculo $3 \mathrm{~mm}$; invólucro cilíndrico, 6-8 $\times$ 1,5-3 mm; brácteas involucrais 1-seriadas, livres, 5 , 7-8 $\times$ 0,6-1 mm, lanceoladas, hirsutas, ápice acuminado, margem inteira, ciliada; receptáculo plano. Flores 5, perfeitas, violetas, corola tubulosa, tubo 3-4 mm, setoso, glanduloso externamente, setoso internamente, lobos setosos, glandulosos; anteras de base aguda, ápice elíptico; ramos do estilete lineares, apêndices conspícuos, pilosos. Cipsela obcônica, $2 \times 0,5 \mathrm{~mm}$, glandulosa, 5-costada; pápus cerdoso, 1-seriado, cerdas alaranjadas, 4-5,5 $\mathrm{mm}$.

Material examinado: BRASIL. Minas Gerais: Uberlândia, Reserva Ecológica do Panga, 26-III-1999, fl., fr., Araújo \& Barbosa s.n. (HUFU19588); IX-1992, bot., Barbosa 487 (HUFU); 20-I-1992, fr., Barbosa 951 (HUFU); 24-III-2000, fl., fr., Barbosa 3458 (HUFU); 30-VII-1999, fl., fr., Barbosa \& Mendes 2668 (HUFU).

Stevia collina é conhecida apenas para o Brasil, nos estados de Minas Gerais, São Paulo e Paraná. Esta espécie ocorre em vereda na REP. S. collina pode ser reconhecida pelas folhas e brácteas involucrais tomentosas a hirsutas e pápus alaranjado.

69. Stevia crenulata Baker, Fl. bras. 6(2): 211. 1876.

Subarbusto, ca. 0,6 m alt.; ramos estriados, setosos. Folhas simples, opostas, sésseis, lâmina 1,2-4 × 0,15-1 cm, lanceolada a oblanceolada; ápice agudo, margem serreada da porção mediana até o ápice, base atenuada; face adaxial setosa, glandulosa, face abaxial tomentosa, glandulosa. Capítulos discóides, em panículas, pedúnculo até $15 \mathrm{~mm}$; invólucro cilíndrico, 7-8 $\times 2 \mathrm{~mm}$; brácteas involucrais 1-seriadas, livres, 5, 6-7 × 1-2 mm, lanceoladas, híspidas, tricomas glandulares, ápice acuminado, margem inteira, ciliada; receptáculo plano. Flores 5 , 
perfeitas, violetas, corola tubulosa, tubo 4-5 $\mathrm{mm}$, setoso, glanduloso externamente, setoso internamente, lobos setosos, glandulosos; anteras de base aguda, ápice elíptico; ramos do estilete lineares, apêndices conspícuos, pilosos. Cipsela obcônica, $3 \times 0,8 \mathrm{~mm}$, glandulosa, 5-costada; pápus cerdoso, 1-seriado, cerdas palhete, base achatada, ca. 5,5 $\mathrm{mm}$.

Material examinado: BRASIL. Minas Gerais: Uberlândia, Reserva Ecológica do Panga, 28-IV-2000, fl., fr., Araújo 3165 (HUFU).

Stevia crenulata é conhecida apenas para o Brasil, nos estados de Minas Gerais, São Paulo, Paraná e no Distrito Federal. Esta espécie ocorre em vereda na REP. $S$. crenulata pode ser reconhecida pelas folhas setosas a tomentosas, brácteas involucrais híspidas e pápus palhete.

70. Stomatanthes trigonus (Gardner) H. Rob., Phytologia 20: 337.1970 E Eupatorium trigonum Gardner, London J. Bot. 6: 446. 1847.

Subarbusto, ca. 1,3 m alt.; ramos angulosos, estriados, setoso-tomentosos, glandulosos. Folhas simples, opostas ou alternas, pecíolo até $7 \mathrm{~mm}$, lâmina 4,5-10,5 × 2,5-7,2 cm, ovada a elíptica; ápice obtuso ou arredondado, margem inteira, base obtusa; face adaxial esparso-setosa, esparso-glandulosa, face abaxial reticulada, tomentosa, glandulosa. Capítulos discóides, em cimeiras, formando panículas terminais laxas, pedúnculo $6 \mathrm{~mm}$; invólucro campanulado, $6 \times$ $3 \mathrm{~mm}$; brácteas involucrais persistentes, 2-seriadas, livres, ca. 7, 3-6 × 1,5-2, lanceoladas, setosas, glandulosas, ápice agudo, esverdeado, margens inteiras, ciliadas; receptáculo plano. Flores 5 , perfeitas, alvas, corola tubulosa, tubo $4,5 \mathrm{~mm}$, glanduloso, lobos glabros; anteras de base aguda, ápice amplo-ovado; ramos do estilete lineares, papilosos, apêndices conspícuos. Cipsela obcônica, 4,5 × 1,5 mm, setosa, glandulosa, 10-costada; pápus cerdoso, 1-seriado, cerdas alvas, $5,5 \mathrm{~mm}$.

Material examinado: BRASIL. Minas Gerais: Uberlândia, Reserva Ecológica do Panga, 21-I-1992, fl., fr., Barbosa 550 (HUFU).

Stomatanthes trigonus ocorre apenas no Brasil, nos estados Mato Grosso, Mato Grosso do Sul, Goiás, Minas Gerais, São Paulo e no Distrito Federal. Esta espécie ocorre em campo sujo seco na REP. $S$. trigonus é reconhecida por suas folhas bastante reticuladas na face abaxial, às vezes alternas.
71. Symphyotrichum regnellii (Baker) G.L. Nesom, Phytologia 77(3): 291. 1994 三Aster regnellii Baker, Fl. bras. 6(3): 21. 1882.

Erva, ca. 1,6 m alt.; ramos estriados, glabros. Folhas alternas, sésseis, lâmina 1-7 ×0,1-0,4 cm, linearlanceolada a lanceolada; ápice acuminado, margem inteira, base amplexicaule; ambas as faces glabras. Capítulos radiados, em panículas, pedúnculo até $8,5 \mathrm{~cm}$, glabro; invólucro campanulado, 5-7 × 7-10 mm; brácteas involucrais persistentes, 3-seriadas, 3-7 $\times$ 0,7-0,9 mm, linear-lanceoladas, glabras, ápice agudo, purpúreo, margem ciliada, receptáculo convexo. Flores do raio ca. 13, pistiladas, amarelas a lilases, corola liguliforme, tubo $3 \mathrm{~mm}$, setoso, limbo $6 \times 2-3 \mathrm{~mm}$, glabro; ramos do estilete lanceolados. Cipsela fusiforme, 1,5 × 0,7 mm, 5-costada, estrigosa; pápus 1 -seriado, cerdoso, $5 \mathrm{~mm}$, amarelado. Flores do disco ca. 33 , perfeitas, amarelas, corola tubulosa, tubo 3-4 mm, lobos glabros; anteras de base aguda, ápice lanceolado; ramos do estilete lineares. Cipsela fusiforme, 1,5-2 × 0,8 mm, 5-costada, glabra; pápus cerdoso, 1-seriado, cerdas $6 \mathrm{~mm}$, amareladas.

Material examinado: BRASIL. Minas Gerais: Uberlândia, Reserva Ecológica do Panga, 27-IV-1994, fl., fr., Nakajima \& Romero 333 (HUFU); 8-IV-1994, fl., fr., Romero \& Nakajima 778 (HUFU).

Symphyotrichum regnellii é conhecida apenas para o Brasil, nos estados de Minas Gerais, Rio de Janeiro, Paraná, Rio Grande do Sul e no Distrito Federal. Esta espécie ocorre em vereda na REP. É reconhecida pela presença de folhas em forma de escamas ao longo dos ramos e pelos capítulos radiados com flores do raio pouco conspícuas, de coloração amarela a lilás.

\section{Tagetes minuta L., Sp. Pl. 2: 887. 1753.}

Subarbusto, ca. 1,3 m alt.; ramos angulosos, costados, glabros. Folhas simples, alternas, sésseis, pinatífidas; ápice agudo, margem crenada, glândulas translúcidas, face adaxial glabra, face abaxial glabra, nervuras estrigosas. Capítulos disciformes, pedúnculo 3-10 mm, em corimbos; invólucro cilíndrico, 8-12 × 2-3 mm; brácteas involucrais persistentes, 1 -seriadas, conadas em quase toda a sua extensão, glândulas esverdeadas, ápice obtuso a arredondado; receptáculo plano. Flores pistiladas amarelas, corola liguliforme, limbo diminuto, tubo $3 \mathrm{~mm}$, estrigoso; ramos do estilete lineares, glabros. Flores perfeitas amarelas, corola tubulosa, tubo $3 \mathrm{~mm}$, estrigoso, lobos estrigosos; 
anteras de base aguda, ápice ovado; ramos do estilete lineares. Cipsela fusiforme, setosa, 7-8 × 0,5-1 mm; pápus paleáceo, páleas 1,5-4 $\mathrm{mm}$, vináceo a palhete.

Material examinado: BRASIL. Minas Gerais: Uberlândia, Reserva Ecológica do Panga, 1993, fl., bot., Barbosa 952 (HUFU).

Tagetes minuta ocorre na Bolívia, Paraguai, Argentina e amplamente no Brasil. Esta espécie ocorre em campo sujo seco na REP. T. minuta é facilmente reconhecida pelas suas folhas pinatífidas com glândulas, além das brácteas involucrais com glândulas, conadas em quase toda a sua extensão.

73. Tilesia baccata (L.) Pruski, Novon 6(4): 414. 1996 $\equiv$ Wulffia baccata (L.) Kuntze, Revis. Gen. Pl. 1: 373. 1891 E Coreopsis baccata L., Pl. Surin. 14. 1775. Wulffia maculata DC., Prodr. 5: 563. 1836.

Subarbusto, ca. 1,5 m alt.; ramos sulcados, estriados, escabros, estrigosos. Folhas simples, opostas, pecíolo 5-20 mm, lâmina 3,5-9 × 0,8-5 cm, ovada a oval-lanceolada; ápice agudo a acuminado, margem serrilhada, base obtusa ou oblíqua; face adaxial escabra, estrigosa, face abaxial tomentosa. Capítulos radiados, em cimeiras simples, pedúnculo 8-35 mm; invólucro globoso, 4-7 × 10-13 mm; brácteas involucrais persistentes, 2-seriadas, tamanhos iguais, 5-6 × 3-3,5 mm, ovadas, estrigosas, ápice agudo, margem inteira; receptáculo convexo, páleas oblongas, amarelas, conduplicadas, $6 \times 2,5 \mathrm{~mm}$, ápice mucronado. Flores do raio ca. 10, neutras, amarelas, corola liguliforme, tubo $1 \mathrm{~mm}$, glabro, limbo 6-7 $\times$ 3-4 mm, glabro, ápice 2-dentado. Cipselas turbinadas, 1,5 × 1 mm, 3-angulosas, glabras, ápice setoso; pápus ausente. Flores do disco ca. 40, perfeitas, amarelas, corola tubulosa, tubo 3,5 mm, glabro, lobos glandulosos; anteras de base aguda a sagitada, ápice triangular; ramos do estilete lanceolados, estrigosos, apêndice inconspícuo. Cipsela turbinada, 2,5 × 1 mm, 3-angulosa, glabra, ápice estrigoso; pápus ausente.

Material examinado: BRASIL. MinAS GERAIs: Uberlândia, Reserva Ecológica do Panga, 26-II-2007, fl., fr., bot., Hattori \& Vargas 525 (HUFU); 19-III-2007, fl., fr., bot., Hattori \& Vargas 539 (HUFU).

Tilesia baccata possui distribuição ampla na América do Sul. Esta espécie ocorre em campo sujo e cerrado sentido restrito na REP. T. baccata é facilmente reconhecida pelas folhas oval-lanceoladas e cipsela carnosa.
74. Trichogonia attenuata G.M. Barroso, Arch. Jard. Bot. Rio de Janeiro 11: 14. 1951.

Subarbusto, ca. 0,5-1,3 m alt.; ramos angulosos, estriados, tomentosos, glandulosos. Folhas simples, alternas, pecíolo 3-13 mm, lâmina 1-6,5 ×0,4-1,6 cm, lanceolada; ápice agudo ou acuminado, margem serrilhada ou crenada, base aguda ou atenuada; face adaxial esparso-estrigosa, glandulosa, face abaxial tomentosa, glandulosa. Capítulos discóides, pedúnculo 3-13 mm, em corimbos terminais; invólucro campanulado 5-7 × 4-9 $\mathrm{mm}$; brácteas involucrais persistentes, 2-seriadas, ca. 10-20, 4,5-7 × 1-2 mm, lanceoladas ou linear-lanceoladas a oblanceoladas, hirsutas, tricomas glandulares sésseis, ápice purpúreo, agudo ou obtuso, margem inteira; receptáculo plano. Flores ca. 20-50, perfeitas, alvas, róseas a lilases ou púrpuras, corola tubulosa, tubo 2,5-3 mm, lobos hirsutos, com tricomas sésseis; anteras de base aguda, ápice ovado; ramos do estilete lineares, apêndices conspícuos, papilosos. Cipsela obcônica, base comprimida, $3-5 \times 0,5 \mathrm{~mm}$, hirsuta, com tricomas sésseis, 5-costada; pápus plumoso, 1-seriado, 2-3 mm.

Material examinado: BRASIL. Minas Gerais: Uberlândia, Reserva Ecológica do Panga, 10-IV-1992, fl., fr., bot., Araújo et al. 16 (HUFU); 22-V-1992, fl., fr., Araújo et al. 142 (HUFU, RB); 19-XII-1986, fl., fr., Araújo s.n. (HUFU824); 16-I-1987, fl., bot., Araújo s.n. (HUFU842); 27-XII-1996, bot., Araújo s.n. (HUFU17985); 21-I-1992, fl., bot., Barbosa 552 (HUFU); 4-III-1988, fl., fr., Barbosa \& Araújo s.n. (HUFU1418); 12-II-2007, fl., fr., bot., Hattori \& Vargas 517 (HUFU); 26-II-2007, f1., fr., bot., Hattori \& Vargas 526 (HUFU).

Trichogonia attenuata é conhecida apenas para o Brasil nos estados do Mato Grosso, Minas Gerais e São Paulo. Esta espécie ocorre em borda de cerradão, campo sujo seco, campo sujo úmido, cerrado sentido restrito, vereda e transição cerrado sentido restritovereda na REP. T. attenuata pode ser reconhecida pelas brácteas involucrais e corola tomentosas e cerdas do pápus plumosas.

75. Trixis glutinosa D. Don, Trans. Linn. Soc. London 16: 189.1833.

Subarbusto, ca. $1 \mathrm{~m}$; ramos cilíndricos, estriados, seríceos. Folhas simples, alternas, sésseis, lâmina 1,5-6,5 × 0,2-1,4 cm, lanceolada a linear-lanceolada; ápice agudo a acuminado, margem inteira a denticulada, base arredondada a aguda; face adaxial 
esparso-setosa, tricomas glandulares, face abaxial vilosa. Capítulos discóides, em corimbos, pedúnculo até $7 \mathrm{~cm}$; invólucro campanulado, 10-15 × 10-15 mm; brácteas involucrais 2-seriadas, livres, 9-15 × 1-2 mm, lanceoladas, com tricomas glandulares, aspecto glutinoso, ápice agudo a arredondado, tricomas presentes ou ausentes; receptáculo plano, cerdoso. Flores ca. 25 , perfeitas, amarelas, corola bilabiada, tubo $7 \mathrm{~mm}$, estrigoso, lobos menores livres entre si, lineares, estrigosos, lobos maiores fundidos, estrigosos; anteras de base acuminada, caudada, ápice oblongo; ramos do estilete truncados, pilosos, glabros abaixo do ponto de bifurcação. Cipsela cilíndrica, glutinosa, 8-10 $\times$ $1 \mathrm{~mm}$; pápus cerdoso, 1 -seriado, cerdas alvas, $11 \mathrm{~mm}$.

Material examinado: BRASIL. Minas Gerais: Uberlândia, Reserva Ecológica do Panga, 21-V-2007, fl., fr., Hattori 746 (HUFU).

Trixis glutinosa ocorre em cerrado ralo na REP. Esta espécie ocorre apenas no Brasil, nos estados da Bahia, Goiás, Minas Gerais, São Paulo e no Distrito Federal T. glutinosa pode ser reconhecida pelas folhas discolores glutinosas na face adaxial, brácteas involucrais glutinosas, flores amarelas e cerdas do pápus alvas.

76. Verbesina glabrata Hook. \& Arn., London J. Bot. 3:315. 1841.

Figura 5

Subarbusto, ca. $1 \mathrm{~m}$ alt.; ramos cilíndricos, estriados, glabros na porção basal, tomentosos na porção apical, folhas simples, alternas espiraladas, pecíolo $5 \mathrm{~mm}$, lâmina 3,5-11,5 × 1-2,5 cm, oblanceolada a espatulada; ápice agudo a obtuso, margem serrilhada, levemente revoluta, base atenuada; face adaxial estrigosa, escabra, face abaxial setoso-tomentosa. Capítulos radiados, pedúnculo 4-20 mm, em panículas terminais; invólucro campanulado, 7-10 × 8-12 mm; brácteas involucrais persistentes, 3-seriadas, 5-8,5 $\times$ 2-3 mm oblonga, tomentosa, ápice arredondado, margem inteira, ciliada; receptáculo convexo, páleas conduplicadas, lanceoladas, glabras, $10 \times 3 \mathrm{~mm}$, ápice obtuso a arredondado. Flores do raio pistiladas, amarelas, corola liguliforme, tubo 2-3 mm, setoso, limbo 9-11 × 4-5 mm, glabro; ramos do estilete lineares. Cipselas turbinadas, 3 -angulosas, glabras, $2 \times 0,5 \mathrm{~mm}$; pápus ausente. Flores do disco perfeitas, amarelas, corola tubulosa, tubo $5 \mathrm{~mm}$, glabro, lobos glabros; anteras de base aguda, ápice ovado; ramos do estilete linear-lanceolados, apêndices inconspícuos, estrigosos.
Cipsela turbinada, 2-3 × 0,6 mm, 3-angulosa, ângulos serrilhados; pápus 1-aristado, arista ca. $2 \mathrm{~mm}$.

Material examinado: BRASIL. Minas Gerais: Uberlândia, Reserva Ecológica do Panga, 21-I-2000, fl., bot., Mendes s.n. (HUFU22279).

Verbesina glabrata ocorre no Brasil nos estados da Bahia, Mato Grosso do Sul, Minas Gerais, Espírito Santo, Rio de Janeiro, São Paulo, Paraná e Santa Catarina. Esta espécie ocorre em vereda na REP. V. glabrata pode ser reconhecida pelas folhas alternas espiraladas, característica incomum para espécies de cerrado pertencentes a tribo Heliantheae.

77. Vernonia bardanoides Less., Linnaea 6: 669. 1831 $\equiv$ Lessingianthus bardanoides (Less.) H. Rob., Proc. Biol. Soc. Wash. 101(4): 940. 1988.

Subarbusto, 0,4-1 m alt.; ramos estriados, híspidotomentosos. Folhas simples, alternas, sésseis, lâmina 1,5-6,5 × 0,6-2,7 cm, oval-lanceolada a lanceolada; ápice agudo a acuminado, mucronado, margem serrilhada, levemente revoluta, base arredondada; face adaxial glabrescente a híspido-tomentosa, escabra, face abaxial tomentosa, glandulosa. Capítulos discóides, sésseis, em cincínios escorpióides folhosos; invólucro globoso, 10-15 × 10-17 mm; brácteas involucrais persistentes, 6-7-seriadas, esquarrosas, 75$120,3-15 \times 0,5-3 \mathrm{~mm}$, lineares a oval-lanceoladas, esverdeadas, estrigosas ou esparso-setosas, ápice acuminado a agudo, margem serrilhada; receptáculo convexo. Flores 75-130, perfeitas, púrpuras, corola tubulosa, tubo 7-12 mm, glabro, lobos glabros; anteras de base sagitada, calcarada, ápice lanceolado; ramos do estilete lineares, pilosos abaixo do ponto de bifurcação. Cipsela obcônica, $3 \times 0,5-0,8 \mathrm{~mm}$, serícea, 5-10-costada; pápus 2-seriado, série interna cerdosa, cerdas 7-10 mm, série externa paleácea, ca. $1 \mathrm{~mm}$.

Material examinado: BRASIL. Minas Gerais: Uberlândia, Reserva Ecológica do Panga, 10-IV-1992, fl., fr., bot., Araújo et al. 44 (HUFU, RB, UEC); 4-III-1988, fl., fr., Barbosa \& Araújo s.n. (HUFU1417); 15-I-1992, bot., Barbosa 514 (HUFU); 7-IV-1992, fl., fr., Barbosa 599 (HUFU); 12-III-2007, fl., bot., Hattori \& Vargas 527 (HUFU).

Vernonia bardanoides ocorre no Paraguai e no Brasil, nos estados da Bahia, Mato Grosso, Goiás, Minas Gerais, Mato Grosso do Sul, São Paulo, Paraná e no Distrito Federal. Esta espécie ocorre em campo 
sujo seco, campo sujo úmido e cerrado ralo na REP. $V$. bardanoides é conhecida pelas brácteas involucrais linear-lanceoladas fortemente esquarrosas, folhas e ramos escabros.

78. Vernonia beyrichii Less., Linnaea 4: 275.1829 $\equiv$ Vernonanthura beyrichii (Less.) H. Rob. Phytologia 73(2): 69. 1992.

Subarbusto, ca. 1,8 m; ramos angulosos, estriados, esparso-estrigosos. Folhas simples, alternas, opostas na porção basal, sésseis, lâmina 2,5-11,5 × 0,4-2 cm, lanceolada; ápice agudo, margens serrilhadas, base atenuada; face adaxial escabra, estrigosa, face abaxial tomentosa, glandulosa. Capítulos discóides ao longo dos ramos, em cincínios folhosos formando corimbos terminais, pedúnculo 5-12 mm; invólucro campanulado, $6 \times 5-6 \mathrm{~mm}$; brácteas involucrais persistentes, imbricadas, 4-seriadas, 1,5-6 × 0,5-1,5 mm, ovadas a lanceoladas, glabras, ápice purpúreo, acuminado, margem ciliada; receptáculo semicôncavo. Flores ca. 15 , perfeitas, violetas, corola tubulosa, tubo $4,5 \mathrm{~mm}$, glabro, lobos glabros; anteras de base sagitada, calcarada, ápice oval-lanceolado; ramos do estilete lineares, pilosos abaixo do ponto de bifurcação.

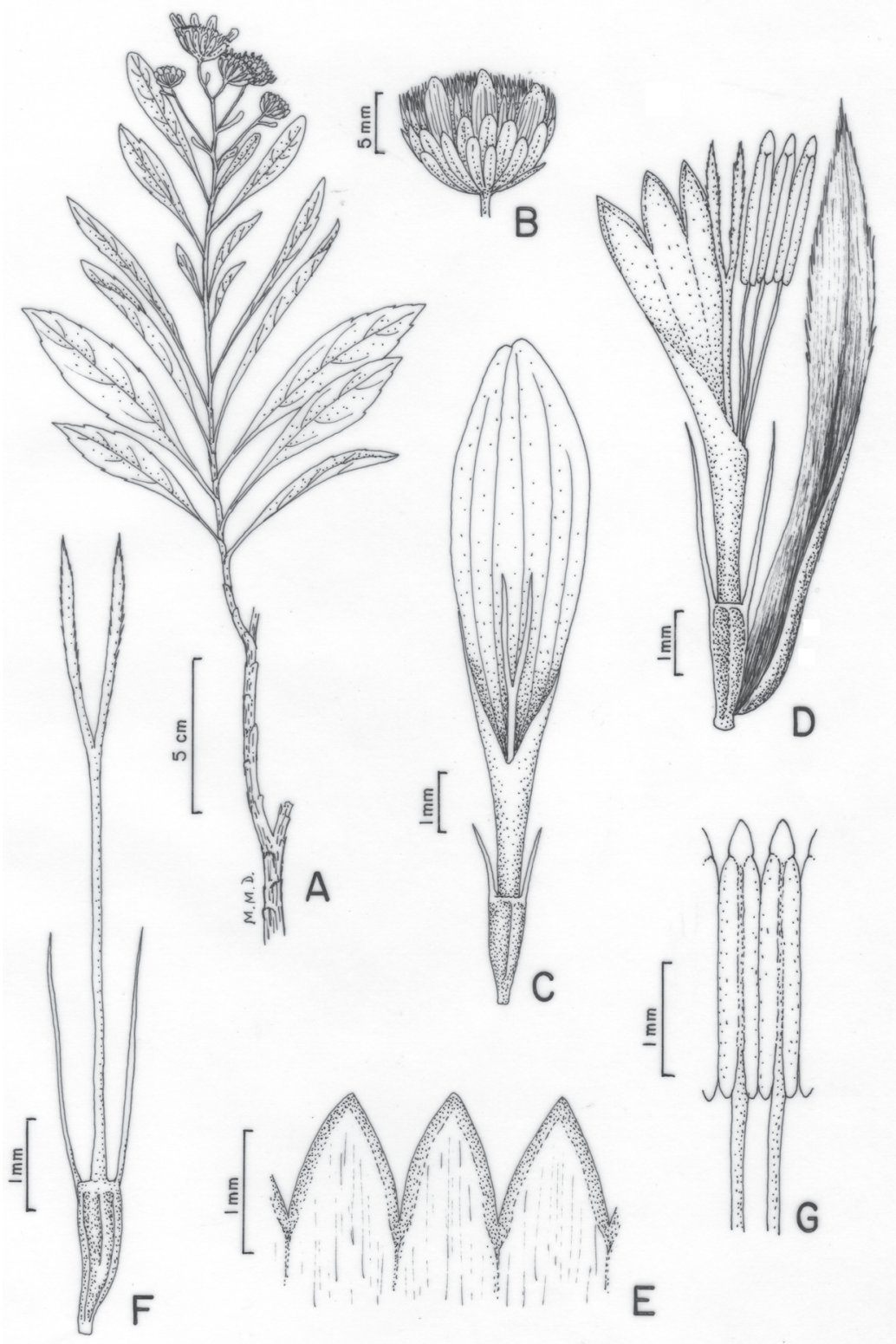

Figura 5. Verbesina glabrata Hook. \& Arn. A) Hábito; B) Capítulo; C) Flor do raio; D) Pálea e flor do disco destacando gineceu e androceu; E) Detalhe dos lobos da corola; F) Estilete, Cipsela e Pápus; G) Anteras. (Mendes s.n., HUFU22279).

Figure 5. Verbesina glabrata Hook. \& Arn. A) Habit; B) Head; C) Ray flower; D) Palea and disc flower, showing androecium and gynoecium; E) Corola lobes in detail; F) Style, Cypsela and Pappus; G) Anthers. (Mendes s.n., HUFU22279). 
Cipselas turbinadas, 1,5-2 $\times 0,8 \mathrm{~mm}$, glandulosas, costas serrilhadas; pápus 2-seriado, amarelado, série interna até $5 \mathrm{~mm}$, série externa $1 \mathrm{~mm}$.

Material examinado: BRASIL. Minas Gerais: Uberlândia, Reserva Ecológica do Panga, 26-II-2007, fl., fr., Hattori \& Vargas 520 (HUFU).

Vernonia beyrichii ocorre no Brasil, nos estados de Minas Gerais, Espírito Santo, Rio de Janeiro, São Paulo, Paraná e no Distrito Federal. Esta espécie ocorre em borda de vereda na REP. $V$. beyrichii é reconhecida pelas folhas semelhantes às encontradas em V.rubriramea e $V$. polyanthes, porém, opostas na porção basal da planta.

79. Vernonia brasiliana (L.) Druce, Bot. Exch. Club Soc. Brit. Isles 3: 426. 1913 [1914] E Vernonanthura brasiliana (L.) H. Rob., Phytologia 73(2): 69. 1992.

Arbusto, ca. 1,8 m alt.; ramos angulosos, costados, avermelhados, estrigoso-tomentosos. Folhas simples, alternas, sésseis a subsésseis, lâmina 1-6,5 × 0,5-1,8 cm, elíptica a oblanceolada; ápice obtuso, margem inteira, levemente revoluta, base obtusa a atenuada; face adaxial estrigosa, escabra, face abaxial tomentosa, glandulosa. Capítulos discóides, pedúnculo 6-14 mm, em cincínios folhosos formando corimbos; invólucro campanulado, 5-6 × 5-6 $\mathrm{mm}$; brácteas involucrais persistentes, 5-6-seriadas, esquarrosas, ca. $55,2-5 \times 0,8-1 \mathrm{~mm}$, ovadas a oval-lanceoladas, esverdeadas, glabras, ápice agudo a acuminado, mucronado, purpúreo, margem inteira; receptáculo plano. Flores ca. 35, perfeitas, alvas a lilases, corola tubulosa, tubo $4 \mathrm{~mm}$, glabro, lobos glabros, anteras de base sagitada, calcarada, ápice oval-lanceolado; ramos do estilete lineares, pilosos abaixo do ponto de bifurcação. Cipsela turbinada $1 \times 0,5 \mathrm{~mm}$; pápus cerdoso, 2-seriado, amarelado, série interna filiforme, caduca, $5,5 \mathrm{~mm}$, série externa plana, $1 \mathrm{~mm}$.

Material examinado: BRASIL. Minas Gerais: Uberlândia, Reserva Ecológica do Panga, 31-VII-1987, fl., bot., Araújo s.n. (HUFU1057).

Vernonia brasiliana ocorre na Bolívia, Paraguai, Argentina e amplamente no Brasil. Esta espécie ocorre em campo sujo seco na REP. $V$. brasiliana é muito semelhante a $V$. ferruginea e $V$. polyanthes pelo tipo de capitulescência, mas difere destas pelo tamanho menor do limbo foliar e também pelo formato mais oblanceolado, e pelo tipo de indumento mais híspido.
80. Vernonia brevifolia Less., Linnaea 4: 285. 1829 $\equiv$ Lessingianthus brevifolius (Less.) H. Rob., Proc. Biol. Soc. Wash. 101(4): 941. 1988.

Erva, ca. 0,4 m alt.; ramos angulosos, estriados, setosos. Folhas simples, alternas, sésseis, lâmina 6-17 × 0,5-1 mm, linear; ápice acuminado, margem inteira, revoluta, base truncada a arredondada; ambas as faces esparso-setosas. Capítulos solitários discóides, sésseis, invólucro campanulado, 7-8 × $13 \mathrm{~mm}$; brácteas involucrais persistentes, 3-4-seriadas, ca. 35, 3-9 $\times$ 1-3 mm, oval-lanceoladas a lanceoladas, esverdeadas, setosas, ápice purpúreo, acuminado, margem serrilhada; receptáculo plano. Flores ca. 35, perfeitas, púrpuras, corola tubulosa, tubo 8-9 mm, estrigoso, lobos glabros; anteras de base sagitada, calcarada, ápice oval-lanceolado; ramos do estilete lineares, pilosos abaixo do ponto de bifurcação. Cipsela obcônica, $2 \times$ 1,2 mm, serícea; pápus cerdoso, 2-seriado, palhete, série interna 6-7 mm, série externa $2 \mathrm{~mm}$.

Material examinado: BRASIL. Minas Gerais: Uberlândia, Reserva Ecológica do Panga, 4-IX-1994, fl., fr., Barbosa 900 (HUFU).

Vernonia brevifolia ocorre no Paraguai, Argentina, Uruguai, e no Brasil, nos estados da Bahia, Mato Grosso, Mato Grosso do Sul, Goiás, Distrito Federal, Minas Gerais, São Paulo, Paraná, Santa Catarina, Rio Grande do Sul e no Distrito Federal. Esta espécie ocorre em campo sujo seco na REP. $V$. brevifolia é bem característica dentre as espécies do gênero encontradas na REP, por possuir folhas bem lineares e reduzidas e capítulos solitários.

81. Vernonia brevipetiolata Sch. Bip. ex Baker, Fl. bras. 6(2): 85. 1873 Eessingianthus brevipetiolatus (Sch. Bip. ex Baker) H. Rob., Proc. Biol. Soc. Wash. 101(4): 941. 1988.

Subarbusto, ca. $1 \mathrm{~m}$ alt.; ramos estriados, cilíndricos ou angulosos, lanuginosos. Folhas simples, alternas, sésseis, lâmina 2,5-14,5 × 0,8-2 cm, linearlanceolada a lanceolada; ápice agudo ou obtuso, margem serrilhada, base aguda a acuminada ou atenuada; face adaxial glabrescente a aracnóide, face abaxial lanuginosa. Capítulos discóides, sésseis, em cincínios folhosos; invólucro estreitocampanulado, 11-13 × 7-10 mm; brácteas involucrais persistentes, 6-seriadas, imbricadas, 45-55, 2-11 $\times$ 1,5-4 mm, orbiculares a lanceoladas nas séries internas, glabras, esverdeadas, glandulosas, aracnóides, ápice purpúreo, agudo a obtuso, margem 
levemente serrilhada; receptáculo plano. Flores ca. 30, perfeitas, púrpuras, corola tubulosa, tubo 8-14 mm, glabro, lobos glabros; anteras de base sagitada, calcarada, ápice lanceolado; ramos do estilete lineares, pilosos abaixo do ponto de bifurcação. Cipsela obcônica, 2,5-3 × 1-1,5 mm, glabra, 8-10-costadas; pápus 2-seriado, série interna cerdosa, cerdas 7-9 $\mathrm{mm}$, série externa paleácea, 1,5-2 mm.

Material examinado: BRASIL. Minas Gerais: Uberlândia, Reserva Ecológica do Panga, 27-III-1987, fl., fr., Araújo s.n. (HUFU928, HEPH); 7-V-1992, fl., fr., Barbosa 598 (HUFU).

Vernonia brevipetiolata ocorre no Brasil, nos estados da Bahia, Goiás, Minas Gerais, São Paulo e no Distrito Federal. Esta espécie ocorre em cerradão e campo sujo seco na REP. $V$. brevipetiolata é muito semelhante a $V$. ligulifolia, mas difere desta pelas folhas com formato mais lanceolado e capítulos em cincínios folhosos, sem agrupar com um ou mais capítulos na axila da folha.

82. Vernonia buddleiifolia Mart. ex DC., Prodr. 5: 45. 1836 =Lessingianthus buddleiifolius (Mart. ex DC.) H. Rob., Proc. Biol. Soc. Wash. 101(4): 941: 1988.

Subarbusto, ca. 1,2 m alt.; ramos cilíndricos, sulcados, lanosos, esbranquiçados. Folhas simples, rosuladas na base, alternas na porção apical, sésseis, lâmina 4,5-23 × 2-5 cm, ovadas a lanceoladas, oblanceoladas a espatuladas; ápice acuminado a agudo ou obtuso, margem dentada a levemente crenada, base aguda a atenuada, face adaxial escabra, estrigosa, face abaxial alvo-lanosa. Capítulos discóides, sésseis, em cincínios escorpióides folhosos; invólucro globoso, 15-20 × 15-20 $\mathrm{mm}$; brácteas involucrais persistentes, 6-8-seriadas, imbricadas, 3-12 × 3-5 mm, amploovadas a oblongas, esverdeadas, esparso-setosas, ápice obtuso a arredondado; receptáculo plano, alveolado. Flores ca. 65, perfeitas, púrpuras, corola tubulosa, tubo $13 \mathrm{~mm}$, glabro, lobos glabros, ápice estrigoso; anteras de base calcarada, ápice ovado; ramos do estilete lineares, pilosos abaixo do ponto de bifurcação. Cipsela turbinada a cilíndrica, $4 \times$ $1 \mathrm{~mm}$, serícea; pápus 2-seriado, série interna, cerdas filiformes $10 \mathrm{~mm}$, série externa, páleas $1,5 \mathrm{~mm}$.

Material examinado: BRASIL. Minas Gerais: Uberlândia, Reserva Ecológica do Panga, 8-V-1992, fr., Araújo et al. 95 (HUFU, UEC); 26-II-2007, fl., fr., bot., Hattori \& Vargas 522 (HUFU).
Vernonia buddleiifolia ocorre no Brasil, nos estados da Bahia, Mato Grosso, Mato Grosso do Sul, Goiás, Minas Gerais, São Paulo, Paraná e no Distrito Federal. Esta espécie ocorre em cerrado sentido restrito na REP. $V$. buddleiifolia pode ser reconhecida pelas folhas espatuladas a oblanceoladas que se encontram rosuladas na base, os capítulos globosos e brácteas involucrais imbricadas, que ficam nigrescentes depois de herborizadas.

83. Vernonia cognata Less., Linnaea 6: 670. 1831 $\equiv$ Chrysolaena platensis (Spreng.) H. Rob., Proc. Biol. Soc. Wash. 101(4): 957. 1988.

Erva escaposa, ca. 0,5 m alt.; ramos estriados, híspido-tomentosos. Folhas simples, alternas, sésseis, lâmina 3-7 × 1-3 cm, elíptica a lanceolada; ápice agudo a obtuso, margens inteiras a serrilhadas, base aguda; face adaxial serícea, glandulosa, face abaxial tomentosa. Capítulos discóides, sésseis, em cincínios folhosos formando corimbos terminais; invólucro campanulado, 8-9 × 5-9 $\mathrm{mm}$; brácteas involucrais persistentes, imbricadas, ca. 30, 4-9 $\times$ 0,5-1,5 mm, linear-lanceoladas a lanceoladas, esverdeadas, setosas, ápice acuminado, purpúreo, margem serrilhada; receptáculo plano. Flores ca. 25 , perfeitas, púrpuras, corola tubulosa, tubo $8 \mathrm{~mm}$, setoso, lobos setosos; anteras de base sagitada, calcarada, ápice oval-lanceolado; ramos do estilete lineares, pilosos abaixo do ponto de bifurcação. Cipsela obcônica, 1,5 × 0,8 mm, serícea, 8-10costada; pápus 2-seriado, alvo, série interna $9 \mathrm{~mm}$, série externa $1 \mathrm{~mm}$.

Material examinado: BRASIL. Minas Gerais: Uberlândia, Reserva Ecológica do Panga, 6-XI-1992, fr., Araújo et al. 373 (HUFU, RB, UEC); 16-X-1992, fr., Araújo et al. 328 (HUFU, RB, UEC); 13-II-1987, fl., fr., bot., Araújo s.n. (HUFU827); 12-III-2007, fl., fr., bot., Hattori \& Vargas 534 (HUFU); 24-X-1986, fl., fr., Schiavini \& Perón s.n. (HUFU761).

Vernonia cognata ocorre no Paraguai, Argentina e no Brasil, nos estados do Tocantins, Mato Grosso, Mato Grosso do Sul, Goiás, Minas Gerais, São Paulo, Paraná, Santa Catarina, Rio Grande do Sul e no Distrito Federal. Esta espécie ocorre em campo sujo seco, campo sujo úmido e cerrado sentido restrito na REP. $V$. cognata é muito semelhante a $V$. herbacea, porém não possui um escapo floral tão acentuado, e as suas folhas possuem formato lanceolado. 
84. Vernonia coriacea Less., Linnaea 6: 661. 1831 $\equiv$ Lessingianthus coriaceus (Less.) H. Rob., Proc. Biol. Soc. Wash. 101(4): 942. 1988.

Subarbusto, ca. $1 \mathrm{~m}$ alt.; ramos cilíndricos, estriados, aracnóides. Folhas simples, alternas, sésseis, lâminas 4-12,5 × 0,6-0,7 cm, linear-lanceolada, coriácea; ápice agudo, margem dentada, levemente revoluta, base truncada; face adaxial esparso-setosa, face abaxial vilosa. Capítulos solitários, discóides, sésseis a subsésseis, pedúnculo até $4 \mathrm{~mm}$; invólucro campanulado, 12-15 × 14-17 mm; brácteas involucrais persistentes, 7-9-seriadas, imbricadas, coriáceas, 3-12 $\times$ 3-4 mm, triangulares a oval-lanceoladas, glabras, ápice agudo; receptáculo plano, alveolado. Flores ca. 80 , perfeitas, púrpuras, corola tubulosa, tubo 7-8 $\mathrm{mm}$, glabro, lobos glabros; anteras de base sagitada, calcarada, ápice ovado; ramos do estilete lineares, pilosos abaixo do ponto de bifurcação. Cipselas turbinadas, 3,5-4 × $1 \mathrm{~mm}$, glabras; pápus 2-seriado, amarelada, série interna com ápice espessado, $9 \mathrm{~mm}$, série externa $1,5 \mathrm{~mm}$.

Material examinado: BRASIL. Minas Gerais: Uberlândia, Reserva Ecológica do Panga, 10-IV-1992, fl., Araújo et al. 35 (HUFU); 12-III-2007, fl., fr., bot., Hattori \& Vargas 537 (HUFU).

Vernonia coriacea ocorre no Peru, Bolívia e Brasil, nos estados de Maranhão, Bahia, Mato Grosso, Mato Grosso do Sul, Goiás, Minas Gerais, São Paulo e no Distrito Federal. Esta espécie ocorre em campo sujo e cerrado sentido restrito na REP. V. coriacea pode ser reconhecida pelas folhas lineares, e o capítulo solitário com brácteas involucrais fortemente imbricadas.

85. Vernonia cuneifolia Gardner, London J. Bot. 5:

215. $1846 \equiv$ Vernonanthura cuneifolia (Gardner)

H. Rob., Phytologia 73(2): 70. 1992.

Subarbusto, ca. $1 \mathrm{~m}$ alt.; ramos angulosos, estriados, puberulentos. Folhas simples, alternas, sésseis, lâmina 1,3-5 × 0,5-2,5 cm, obovada a oblanceolada; ápice arredondado ou obtuso, margem inteira a denteada, levemente revolutas, base aguda ou atenuada; face adaxial setosa ou tomentosa, glandulosa, face abaxial lanuginosa. Capítulos discóides, em panículas definidas formadas por grupos de 3-7 capítulos; invólucro campanulado, 6-7 × 4-5 mm; brácteas involucrais persistentes, 6-7-seriadas, imbricadas, ca. 25, 1-6 × 0,5-1 mm, oval-lanceoladas a lanceoladas, esverdeadas, glabras, ápice agudo ou obtuso, purpúreo, glanduloso, margem ciliada; receptáculo plano. Flores 8-10, perfeitas, lilases, corola tubulosa, tubo $4 \mathrm{~mm}$, glabro, lobos glabros; anteras de base sagitada, calcarada, ápice lanceolado; ramos do estilete lineares, pilosos abaixo do ponto de bifurcação. Cipsela obcônica, $1 \times 0,6-1 \mathrm{~mm}$, 5-costada, glandulosa; pápus cerdoso, 2-seriado, série interna 4-5 mm, série externa $0,5 \mathrm{~mm}$.

Material examinado: BRASIL. Minas Gerais: Uberlândia, Reserva Ecológica do Panga, 2-VI-2000, bot., Araújo s.n. (HUFU23475); 26-V-2000, bot., Barbosa 3379 (HUFU); 30-VII-1999, fl., fr., Barbosa \& Mendes 2081 (HUFU); 25-VI-1999, fl., fr., Faria s.n. (HUFU20535); 27-VIII-1999, fl., fr., Lemos s.n. (HUFU21231).

Vernonia cuneifolia ocorre no Paraguai e no Brasil, nos estados do Mato Grosso, Mato Grosso do Sul, Goiás, Minas Gerais, São Paulo, Paraná, Santa Catarina e no Distrito Federal. Esta espécie ocorre em vereda na REP. V. cuneifolia pode ser reconhecida pela folha em forma de cunha e pelos capítulos dispostos em panículas definidas compostas de 3-7 capítulos.

86. Vernonia desertorum Mart. ex DC., Prodr. 5: 43. 1836 E Lessingianthus desertorum (Mart. ex DC.) H. Rob., Proc. Biol. Soc. Wash. 101(4): 950. 1988.

Erva com xilopódio, ca. $0,15 \mathrm{~m}$ alt.; ramos estriados, híspidos. Folhas simples alternas, sésseis, lâmina 1,2-6 × 0,1-0,4 cm, linear; ápice acuminado, margem inteira, levemente revoluta, base atenuada; ambas as faces hirsutas, face abaxial glandulosa. Capítulos solitários, discóides, sésseis; invólucro campanulado, 10-11 × $12 \mathrm{~mm}$; brácteas involucrais persistentes, 2-seriadas, imbricadas, ca. 15, lanceoladas a linear-lanceoladas, esverdeadas, hirsutas, glandulosas, ápice acuminado, margem serrilhada; receptáculo plano. Flores ca. 30, perfeitas, púrpuras, corola tubulosa, tubo $7 \mathrm{~mm}$, glabro, lobos glabros; anteras de base sagitada, calcarada, ápice lanceolado; ramos do estilete lineares, pilosos abaixo do ponto de bifurcação, ápice agudo. Cipsela obcônica, $2 \times$ $1,5 \mathrm{~mm}$, serícea; pápus 2 -seriado, série interna 6-7 $\mathrm{mm}$, série externa $1 \mathrm{~mm}$.

Material examinado: BRASIL. Minas Gerais: Uberlândia, Reserva Ecológica do Panga, 24-IX-1992, fl., fr., Araújo et al. 280 (HUFU, RB). 
Vernonia desertorum ocorre no Paraguai e no Brasil, ocorrendo nos estados da Bahia, Mato Grosso, Mato Grosso do Sul, Goiás, Minas Gerais, São Paulo, Paraná e no Distrito Federal. Esta espécie ocorre em cerrado sentido restrito na REP, sendo facilmente reconhecida pelo seu porte baixo e capítulo solitário grande em relação a sua altura.

87. Vernonia echitifolia Mart. ex DC., Prodr. 5: 60. 1836 E Acilepidopsis echitifolia (Mart. ex DC.) H. Rob., Phytologia 67(4): 291. 1989.

Subarbusto, ca. $1 \mathrm{~m}$ alt.; ramos angulosos, estriados, gríseo-tomentosos, glandulosos. Folhas simples, alternas, pecíolo 3-5 mm, lâmina 0,5-5 × 0,3-2,5 cm, elíptica a ovada; ápice agudo a obtuso, margem inteira a denteada, base aguda ou obtusa; face adaxial estrigosa, glandulosa, nervuras gríseotomentosas, face abaxial gríseo-tomentosa, glandulosa. Capítulos discóides, sésseis, em cincínios folhosos eretos, dando um aspecto espiciforme; invólucro campanulado, 6-8 $\times$ 4-6 mm; brácteas involucrais persistentes, 4-6-seriadas, 25-35, 1-7 × 0,5-2 mm, triangulares, lanceoladas a oval-lanceoladas, esverdeadas, tomentosas a hirsutas, glandulosas, ápice verdeescuro, agudo a acuminado, margem inteira, ciliada; receptáculo plano a levemente convexo. Flores 11-12, perfeitas, púrpuras, corola tubulosa, tubo 3-4 mm, glabro, ápice 5-lobado, lobos setosos, glandulosos; anteras de base sagitada, calcarada, ápice lanceolado; ramos do estilete lineares, pilosos abaixo do ponto de bifurcação. Cipsela obcônica, 1,5 × 1-1,5 mm, glandulosa, 5-costada; pápus 2-seriado, alvo, série interna 4-6 mm, série externa 1-1,5 mm.

Material examinado: BRASIL. Minas Gerais: Uberlândia, Reserva Ecológica do Panga, 18-II-2000, fl., fr., Amaral \& Cardoso s.n. (HUFU22460); 15-V-1992, fl., fr., Araújo et al. 108 (HUFU, RB, UEC); 30-IV-1999, fl., fr., Barbosa \& Faria 2002 (HUFU); 23-IV-1999, fl., fr., Faria \& Araújo 2515 (HUFU); 7-V-2007, fl., fr., Hattori 732 (HUFU); 21-I-2000, fl., bot., Mendes s.n. (HUFU22267).

Vernonia echitifolia ocorre na Bolívia, Paraguai, Argentina, Uruguai e no Brasil, nos estados do Mato Grosso, Mato Grosso do Sul, Goiás, Minas Gerais, São Paulo, Paraná, Santa Catarina, Rio Grande do Sul e no Distrito Federal. Esta espécie ocorre em vereda, campo sujo seco e campo sujo úmido na REP. $V$. echitifolia é facilmente reconhecida pelas folhas elípticas e os capítulos arranjados em cincínios eretos, tendo aspecto de espiga.

88. Vernonia ferruginea Less., Linnaea 4: 271. 1829

三Vernonanthura ferruginea (Less.) H. Rob., Phytologia 73(2): 70. 1992.

Arbusto, ca. $2 \mathrm{~m}$ alt.; ramos estriados, alvotomentosos. Folhas simples, alternas, pecíolo 2-4 mm, lâmina 1,5-8,5 ×0,8-4,5 cm, elíptica a oval-lanceolada; ápice obtuso ou truncado, margem inteira ou levemente crenada, levemente revoluta, base truncada ou obtusa; face adaxial glandulosa, face abaxial alvo-tomentosa. Capítulos discóides, sésseis, em cincínios folhosos formando panículas; invólucro campanulado, 5-6 $\times$ 4-5 $\mathrm{mm}$; brácteas involucrais persistentes, esquarrosas, 5-6-seriadas, ca. 70, 1-3 × 0,8-1,2 mm, ovadas a oval-lanceoladas, esverdeadas, setosas a glabrescentes, ápice obtuso a agudo, margem ciliada; receptáculo plano. Flores ca. 25, perfeitas, creme, corola tubulosa, tubo 3-4 mm, glabro, lobos glabros; anteras de base sagitada, calcarada, ápice ovallanceolado; ramos do estilete lineares, pilosos abaixo do ponto de bifurcação. Cipsela obcônica, 1,5-2,5 $\times$ $0,8 \mathrm{~mm}, 8$-10-costada, glandulosa, estrigosa; pápus cerdoso, 2-seriado, cerdas com ápice espessado, série interna $4 \mathrm{~mm}$, série externa $0,8 \mathrm{~mm}$.

Material examinado: BRASIL. Minas Gerais: Uberlândia, Reserva Ecológica do Panga, 29-VII-1997, fr., Araújo 1990 (HUFU); 31-IV-1987, fl., fr., Araújo s.n. (HUFU1058).

Vernonia ferruginea ocorre no Peru, Bolívia, Paraguai e amplamente no Brasil, com exceção a região Sul. Esta espécie ocorre em campo sujo seco e transição cerrado sentido restrito-vereda na REP. $V$. ferruginea é muito semelhante a $V$. polyanthes e V. rubriramea pela disposição dos capítulos e formato da folha, mas difere desta pelo indumento mais esbranquiçado e mais denso.

89. Vernonia fruticulosa Mart. ex DC., Prodr. 5: 53.

$1836 \equiv$ Lepidaploa rufogrisea (A. St.-Hil.) H. Rob., Proc. Biol. Soc. Wash. 103(2): 492. 1990.

Subarbusto, ca. 1,2 m alt.; ramos cilíndricos, estriados, estrigoso-tomentosos. Folhas simples, alternas, sésseis, lâmina 2-8,5 × 0,5-1,5 cm, lanceolada a linear-lanceolada; ápice agudo a acuminado, margem inteira a levemente serrilhada, base atenuada; face adaxial verde, setosa, glandulosa; face abaxial acinzentada, tomentosa, glandulosa. Capítulos 
discóides, sésseis, em corimbos terminais; invólucro cilíndrico, 8-9 × 4-5 mm; brácteas involucrais persistentes, 4-6-seriadas, esquarrosas, de 25-30, 1,5-8 $\times 1-2,5 \mathrm{~mm}$, esverdeadas, esparso-setosas, glandulosas, ápice mucronado, purpúreo, glanduloso, margem serrilhada; receptáculo plano, alveolado. Flores 11, perfeitas, purpúreas, corola tubulosa, tubo $4 \mathrm{~mm}$, setoso, glanduloso, lobos glandulosos, setosos; anteras de base sagitada, calcarada, ápice ovado; ramos do estilete lineares, pilosos abaixo do ponto de bifurcação. Cipsela obcônica, $2 \times 1 \mathrm{~mm}$, serícea; pápus cerdoso, 2-seriado, amarelo, série interna $7 \mathrm{~mm}$, série externa, 1,5 $\mathrm{mm}$.

Material examinado: BRASIL. Minas Gerais: Uberlândia, Reserva Ecológica do Panga, 7-V-2007, fl, fr., bot., Hattori 726 (HUFU); 21-V-2007, fl., fr., Hattori 741 (HUFU); 13-IX-2007, fr., Hattori 802 (HUFU).

Vernonia fruticulosa ocorre apenas no Brasil, nos estados do Tocantins, Bahia, Mato Grosso, Goiás, Minas Gerais, Rio de Janeiro, São Paulo e no Distrito Federal. Esta espécie ocorre em cerrado sentido restrito na REP. $V$. fruticulosa pode ser reconhecida pelos capítulos em corimbos terminais folhosos, com brácteas involucrais internas púrpuras.

90. Vernonia herbacea (Vell.) Rusby, Mem. Torrey Bot. Club 4(3): 209. 1895 EChrysolaena herbacea (Vell.) H. Rob., Proc. Biol. Soc. Wash. 101(4): 956. 1988.

Erva escaposa, ca. 0,6 m alt.; ramos estriados, seríceo-tomentosos, angulosos. Folhas simples, alternas, sésseis, lâmina 2,5-5 × 0,4-2,2 cm, lanceolada a oval-lanceolada; ápice agudo ou acuminado, margem serrilhada, base aguda ou obtusa; face adaxial híspida ou serícea, face abaxial tomentosa. Capítulos discóides, sésseis, em cincínios escorpióides folhosos formando corimbos terminais; invólucro campanulado, 6-8 $\times$ 6-8 $\mathrm{mm}$; brácteas involucrais persistentes, esquarrosas, 3-seriadas, 25-30, 3-8 × 1-1,5 mm, ovallanceoladas a lanceoladas, seríceas, esverdeadas, ápice acuminado ou agudo, esverdeado, margem inteira ou serrilhada, ciliada; receptáculo plano, alveolado. Flores 20-30, perfeitas, púrpuras, corola tubulosa, tubo 6-7 mm, glabra, lobos setosos no ápice; anteras de base sagitada, calcarada, ápice lanceolado; ramos do estilete lineares, pilosos abaixo do ponto de bifurcação. Cipsela obcônica, $2 \times 1 \mathrm{~mm}, 8$-10-costada, estrigosa; pápus 2-seriado, cerdas alvas, série interna 5-9 mm, série externa 1-1,5 mm.
Material examinado: BRASIL. Minas Gerais: Uberlândia, Reserva Ecológica do Panga, 20-IX-1992, fr., Barbosa 775 (HUFU); 23-X-1992, Araújo et al. 354 (HUFU); 30-X-1993, fl., fr., Barbosa 702 (HUFU); 4-IX-1994, fl., fr., Barbosa 947 (HUFU).

Vernonia herbacea ocorre no Peru, Bolívia, Paraguai e amplamente no Brasil. Esta espécie ocorre em campo sujo seco pós-fogo na REP. $V$. herbacea é muito semelhante a Vernonia cognata, porém difere desta por possuir os capítulos em escapo floral pronunciado e as folhas com formato mais ovalado.

91. Vernonia ligulifolia Mart. ex DC., Prodr. 5: 46. $1836 \equiv$ Lessingianthus ligulifolius (Mart. ex DC.) H. Rob., Proc. Biol. Soc. Wash. 101(4): 944. 1988.

Arbusto, ca. 1,2 m alt.; ramos angulosos, estriados, aracnóides. Folhas simples, alternas, lâmina 3-14 × 0,7-1,7 cm, lanceolada a linear-lanceolada; ápice agudo ou obtuso, margem inteira, base aguda; face adaxial glandulosa, face abaxial lanuginosa. Capítulos discóides, sésseis, isolados em cincínios folhosos; invólucro estreito-campanulado, 11-13 × 8-10 mm; brácteas involucrais persistentes, esquarrosas, 5-6-seriadas, ca. 50, 2-11 × 2-5 mm, triangulares, ovadas a lanceoladas, esverdeadas, glabrescentes a estrigosas, ápice acuminado a obtuso, margem inteira, ciliada; receptáculo plano, alveolado. Flores ca. 20, perfeitas, púrpuras, corola tubulosa, tubo $10 \mathrm{~mm}$, glabro, lobos glabros; anteras de base sagitada, calcarada, ápice lanceolado; ramos do estilete lineares, pilosos abaixo do ponto de bifurcação. Cipsela obcônica, $3 \times 1,5 \mathrm{~mm}$, glabra, 10-costada; pápus cerdoso, 2-seriado, cerdas palhete, série interna 8-9 mm, série externa $1 \mathrm{~mm}$.

Material examinado: BRASIL. Minas Gerais: Uberlândia, Reserva Ecológica do Panga, 19-I-1993, fl., fr., bot., Melo et al. 26 (HUFU, UEC); 12-III-2007, fl., fr., bot., Hattori \& Vargas 529 (HUFU).

Vernonia ligulifolia ocorre no Brasil, nos estados do Tocantins, Maranhão, Bahia, Mato Grosso, Goiás, Minas Gerais, São Paulo e no Distrito Federal. Esta espécie ocorre em cerradão e cerrado ralo na REP. $V$. ligulifolia é reconhecida pelas folhas alongadas e os capítulos robustos isolados nas axilas foliares ao longo do ramo, formando cincínios.

92. Vernonia obtusata Less., Linnaea 6: 662. 1831 $\equiv$ Lessingianthus obtusatus (Less.) H. Rob., Proc. Biol. Soc. Wash. 101(4): 946. 1988. 
Subarbusto, ca. 1,7 m alt.; ramos estriados, glabrescentes. Folhas simples, alternas, pecíolo $4 \mathrm{~mm}$, lâmina 1,3-6 × 0,5-3 cm, elíptica a ovada; ápice agudo ou obtuso, margem serrilhada, base oblíqua, aguda ou obtusa; face adaxial glabra, face abaxial glandulosa. Capítulos discóides, sésseis, isolados em cincínios folhosos; invólucro campanulado, 6-9 × 4-5 mm; brácteas involucrais persistentes, esquarrosas, 5-6-seriadas, 30-35, 1,5-7 × 1-2 mm, triangulares a lanceoladas, glabrescentes, esverdeadas, ápice agudo ou obtuso, glanduloso, setoso, margem serrilhada, ciliada; receptáculo plano, alveolado. Flores 11, perfeitas, alvas a creme, corola tubulosa, tubo 3,5-4 mm, glabro, lobos glabros; anteras de base sagitada, calcarada, ápice ovado; ramos do estilete lineares, pilosos abaixo do ponto de bifurcação. Cipsela obcônica, 2-2,5 × $1 \mathrm{~mm}$, serícea, glandulosa, 10-costada; pápus cerdoso, 2-seriado, palhete, série interna 4-4,5 mm, série externa $1 \mathrm{~mm}$.

Material examinado: BRASIL. Minas Gerais: Uberlândia, Reserva Ecológica do Panga, 28-IV-2000, fr., Araújo 3170 (HUFU); 18-VI-1999, fr., Araújo \& Faria s.n. (HUFU20404); 26-II-2007, fl., fr., Hattori \& Vargas 524 (HUFU).

Vernonia obtusata ocorre na Bolívia e no Brasil, nos estados do Tocantins, Bahia, Mato Grosso, Mato Grosso do Sul, Goiás, Minas Gerais, São Paulo e no Distrito Federal. Esta espécie ocorre em cerrado sentido restrito e vereda na REP. V. obtusata pode ser reconhecida pelas folhas glabras e com retículos bem pronunciados.

93. Vernonia petiolaris DC., Prodr. 5: 37.1836 $\equiv$ Vernonanthura petiolaris (DC.) H. Rob., Phytologia 73(2): 73.1992.

Arbusto, ca. 2,5 m alt.; ramos angulosos, estriados, estrigosos, glandulosos. Folhas simples, alternas, pecíolo 4-6 mm, lâmina 2,2-6 × 1,1-2 cm, lanceolada; ápice agudo ou acuminado, margem serrilhada, levemente revoluta, base acuminada ou atenuada; face adaxial estrigosa, glandulosa, nervuras tomentosas, face abaxial tomentosa, glandulosa. Capítulos discóides, em cincínios escorpióides folhosos formando corimbos terminais, pedúnculo 2-10 mm; invólucro campanulado, 6-7 × 4-5 $\mathrm{mm}$; brácteas involucrais persistentes, esquarrosas, 4-seriadas, ca. 40, 3,5-6 × 0,5-1 mm, linear-lanceoladas a lanceoladas, esverdeadas, glabras, ápice acuminado, margem inteira, ciliada; receptáculo plano. Flores ca. 20, perfeitas, alvas, corola tubulosa, tubo $6 \mathrm{~mm}$, glabro, lobos glabros; anteras de base sagitada, calcarada, ápice lanceolado; ramos do estilete lineares, pilosos abaixo do ponto de bifurcação. Cipsela obcônica, $2 \times 1 \mathrm{~mm}$, glandulosa, 10-costada; pápus cerdoso, 2-seriado, cerdas amarelas, série interna ca. $5,5 \mathrm{~mm}$, série externa $1 \mathrm{~mm}$.

Material examinado: BRASIL. Minas Gerais: Uberlândia, Reserva Ecológica do Panga, 20-III-1987, fl., fr., Araújo s.n. (HUFU962).

Vernonia petiolaris ocorre nos estados de Minas Gerais, Espírito Santo, Rio de Janeiro e São Paulo e Paraná. Esta espécie ocorre em campo sujo úmido na REP. $V$. petiolaris é muito parecida com $V$. rubriramea por possuir as folhas lanceoladas, mas difere desta por possuir capítulos em corimbos laxos ao contrário de $V$. rubriramea que possui os capítulos em panículas congestas.

94. Vernonia polyanthes Less., Linnaea 6: 651. 1831 三Vernonanthura phosphorica (Vell.) H. Rob., Phytologia 73(2): 73. 1992.

Arbusto, ca. 2,5 m alt.; ramos sulcados, glabrescentes. Folhas simples, alternas, sésseis, lâmina 1-11,5 × 0,4-2,5 cm, linear-lanceolada a lanceolada; ápice agudo ou acuminado, margem serrilhada, base atenuada; face adaxial esparso-estrigosa, glandulosa, face abaxial estrigosa, glandulosa. Capítulos discóides, sésseis, em cincínios escorpióides folhosos formando panículas; invólucro campanulado, 4-5 × 3-4 mm; brácteas involucrais persistentes, esquarrosas, 6-seriadas, ca. 30-50, 1-4 × 1-2 mm, ovadas a ovallanceoladas ou lanceoladas, glabras, esverdeadas, ápice agudo ou obtuso, purpúreo, glanduloso, estrigoso, margem inteira, ciliada; receptáculo côncavo. Flores ca. 15-20, perfeitas, alvas a róseas, corola tubulosa, tubo $4 \mathrm{~mm}$, lobos glabros; anteras de base sagitada, calcarada, ápice lanceolado a oval-lanceolado; ramos do estilete lineares, pilosos abaixo do ponto de bifurcação. Cipsela obcônica, 1-2 × 0,5-0,6 mm, estrigosa, 10-costada; pápus cerdoso, 2-seriado, série interna 3,5-4,5 mm, ápice espessado, série externa 0,5-1 mm.

Material examinado: BRASIL. Minas Gerais: Uberlândia, Reserva Ecológica do Panga, 26-V-2000, fl., fr., Araújo 3247 (HUFU); 29-IV-1997, bot., Araújo s.n. (HUFU17999); 27-IV-1992, fl., fr., bot., Barbosa 606 (HUFU); 7-V-2007, fl., fr., bot., Hattori 729 (HUFU); 25-VI-1999, fr., Lemos s.n. (HUFU20763). 
Vernonia polyanthes ocorre no Paraguai e amplamente Brasil. Esta espécie ocorre em campo sujo seco, cerradão, cerrado sentido restrito, transição cerrado sentido restrito-vereda e vereda na REP. $V$. polyanthes é muito comumente confundida com V. rubriramea, pela disposição dos capítulos nos ramos e o formato da folha. No entanto, diferencia-se de $V$. rubriramea por possuir capítulos mais robustos e ramos com sulcos mais profundos.

95. Vernonia rubricaulis Bonpl., $\mathrm{Pl}$. Aequinoct. 2: 66, t. 99. 1809 [1810-1811] $\equiv$ Lessingianthus rubricaulis (Bonpl.) H. Rob., Proc. Biol. Soc. Wash. 101(4): 948. 1988.

Figura 6

Arbusto, ca. 2 m alt.; ramos cilíndricos, estriados, avermelhados, estrigosos. Folhas simples, alternas, sésseis, lâmina 2-10,5 × 0,1-0,45 cm, linear; ápice acuminado, margem inteira, levemente revoluta, base longo-atenuada; face adaxial esparso-estrigosa, esverdeada, face abaxial alvo-lanuginosa. Capítulos discóides, sésseis, isolados em cincínios escorpióides folhosos; invólucro campanulado, $6 \times 5 \mathrm{~mm}$; brácteas involucrais persistentes, 5-seriadas, imbricadas, 3-6 $\times$ 1-2 mm, ovadas a lanceoladas, purpúreas, glandulosas, estrigosas na porção apical, ápice acuminado, margem ciliada na porção apical; receptáculo plano. Flores ca. 20, perfeitas, púrpuras, corola tubulosa, tubo $7 \mathrm{~mm}$, glabro, lobos glabros; anteras de base sagitada, calcarada, ápice oval-lanceolado; ramos do estilete linear-lanceolados, pilosos abaixo do ponto de bifurcação. Cipsela fusiforme a obcônica, 10-costada, glabra, estrigosa no ápice; pápus cerdoso 2-seriado, série interna, cerdas filiformes espessadas no ápice, $5 \mathrm{~mm}$, série externa, cerdas planas, $1 \mathrm{~mm}$.

Material examinado: BRASIL. Minas Gerais: Uberlândia, Reserva Ecológica do Panga, 27-III-1987, fl., fr., bot., Araújo s.n. (HUFU972, UEC).

Vernonia rubricaulis ocorre no Paraguai, Argentina e no Brasil, nos estados do Mato Grosso do Sul, Minas Gerais, São Paulo, Paraná e Rio Grande do Sul. Esta espécie ocorre em campo sujo úmido na REP. V. rubricaulis é facilmente reconhecida pelos seus ramos avermelhados e folhas com a face adaxial lanuginosa.

96. Vernonia rubriramea Mart. ex DC., Prodr. 5: 38. 1836.

Arbusto, ca. 3 m alt.; ramos cilíndricos, costados, esparso-estrigosos. Folhas simples, alternas, sésseis, lâmina 3-10,5 × 1-2,8 cm, lanceolada a elíptica; ápice agudo a obtuso, margem levemente serreada, levemente revoluta; face adaxial estrigosa, face abaxial esparso-estrigosa. Capítulos discóides, em cincínios escorpióides folhosos formando panículas; invólucro globoso, 4-5 × 3-4 mm; brácteas involucrais persistentes, 5-seriadas, ca. 30, 1,5-4,5 × 1-1,5 mm, linear-lanceoladas a ovadas, esverdeadas, ápice obtuso a agudo, purpúreo, estrigoso, margem ciliada; receptáculo plano a levemente côncavo. Flores ca. 20 , perfeitas, róseas a alvas, corola tubulosa, tubo $5,5 \mathrm{~mm}$, glabro, lobos glabros; anteras de base sagitada, calcarada, ápice oval-lanceolado; ramos do estilete lineares, pilosos abaixo do ponto de bifurcação. Cipsela cilíndrica a turbinada, $1 \times 0,5 \mathrm{~mm}$, serrilhada; pápus cerdoso, 2-seriado, série interna 4-5 mm, série externa $0,5 \mathrm{~mm}$.

Material examinado: BRASIL. Minas Gerais: Uberlândia, Reserva Ecológica do Panga, 28-IV-2000, bot., Araújo 3174 (HUFU); 8-V-1992, fl., fr., Araújo et al. 67 (HUFU, RB); 30-IV-1999, fl., bot., Barbosa \& Faria 2023 (HUFU).

Vernonia rubriramea é conhecida apenas para o Brasil, nos estados do Pará, Mato Grosso, Mato Grosso do Sul, Goiás, Minas Gerais, São Paulo e no Distrito Federal. Esta espécie ocorre em cerradão, cerrado sentido restrito e vereda na REP. $V$. rubriramea é muito semelhante a $V$. polyanthes, tendo suas diferenças já citadas anteriormente.

97. Viguiera discolor Baker, Fl. bras. 6(3): 228. 1884.

Subarbusto, ca. $0,8 \mathrm{~m}$ alt.; ramos angulosos, costados, híspidos. Folhas simples, opostas e alternas na mesma planta, sésseis, lâmina 4,5-10,5 × 2-5,5 cm, ovada a oval-lanceolada; ápice agudo ou obtuso, margem inteira a levemente crenada, base arredondada, semi-amplexicaule; face adaxial esparso-setosa, híspida nas nervuras, face abaxial tomentosa, com pontuações glandulares sésseis. Capítulos radiados, solitários, pedúnculo até $15 \mathrm{~cm}$; invólucro globoso, $10 \times 15 \mathrm{~mm}$; brácteas involucrais 3-seriadas, 7-9 × 2-3 mm, lanceoladas, esverdeadas, densamente ciliadas na margem, ápice agudo a acuminado, híspido; receptáculo levemente convexo, páleas conduplicadas, $6 \times 1,5-2 \mathrm{~mm}$, estrigosa na porção mediana, ápice obtuso, margem inteira. Flores do raio 12-21, neutras, amarelas, corola liguliforme, tubo $1 \mathrm{~mm}$, limbo $15-19 \mathrm{~mm}$, estriado, estrigoso. Cipsela abortiva, turbinada, 3-angulosa, glabra; pápus 
aristado-coroniforme. Flores do disco 145-150, perfeitas, amarelas, corola tubulosa, tubo $3 \mathrm{~mm}$, glabra, lobos estrigosos, glandulosos; anteras de base sagitada, ápice ovado; ramos do estilete lineares, apêndices inconspícuos. Cipsela falciforme, achatada, 2,5-3 × 1,5 mm, glabra; pápus aristado-coroniforme, $2,5 \mathrm{~mm}$.

Material examinado: BRASIL. Minas Gerais: Uberlândia, Reserva Ecológica do Panga, 6-XI-1992, fl., bot., Araújo et al. 383 (HUFU, SPF, UEC);
30-X-1993, fl., Barbosa 703 (HUFU); 23-X-1987, fl., Barbosa s.n. (HUFU1210); 16-X-1987, fl., bot., Schiavini s.n. (HUFU1199).

Viguiera discolor ocorre apenas no Brasil, nos estados de Minas Gerais, Goiás, São Paulo e Paraná. Esta espécie ocorre em campo sujo seco, cerrado sentido restrito, e cerrado ralo na REP. $V$. discolor pode ser reconhecida pelas folhas com base semiamplexicaule, e os capítulos solitários em ramos longos.
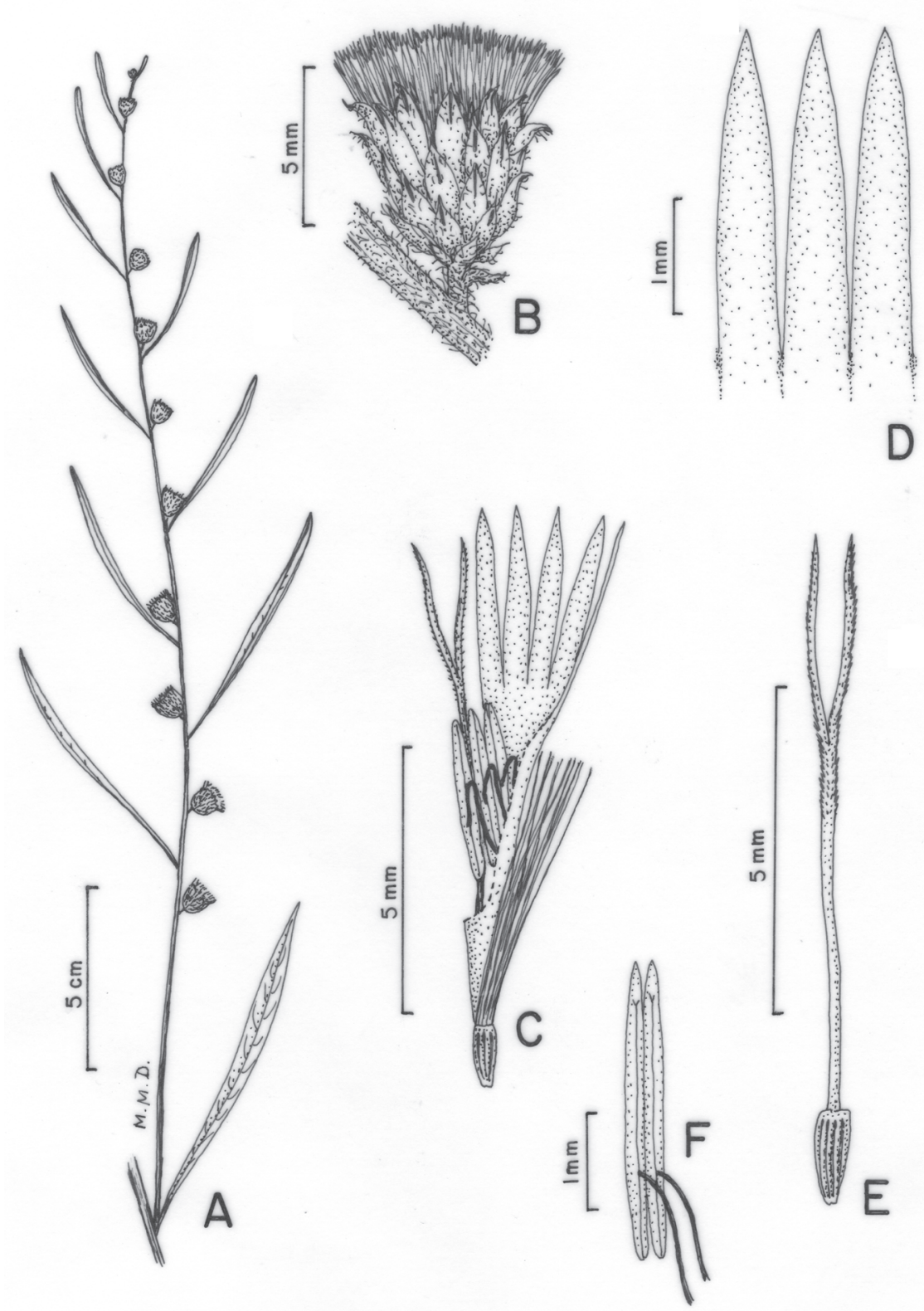

Figura 6. Vernonia rubricaulis Bonpl. A) Hábito; B) Capítulo; C) Flor, mostrando androceu e gineceu; D) Detalhe dos lobos da corola; E) Estilete e Cipsela; F) Anteras. (Araújo s.n. HUFU972).

Figure 6. Vernonia rubricaulis Bonpl. A) Habit; B) Head; C) Flower, showing androcecium and gynoecium; D) Corola lobes in detail; E) Style and Cypsela; F) Anthers. (Araújo s.n. HUFU972). 
98. Viguiera robusta Gardner, London J. Bot. 7: 403. 1848.

Subarbusto, ca. 1,5 m alt.; ramos cilíndricos, estriados, estrigosos. Folhas simples, alternas, sésseis, lâmina 1-6 ×0,5-3 cm, ovada a oval-lanceolada; ápice agudo ou obtuso, margem serrilhada, base truncada ou arredondada; face adaxial glabra a estrigosa, nervuras setosas, face abaxial glandulosa, nervuras híspidas. Capítulos radiados em corimbos, longos e laxos, pedúnculo 4,5-14,5 cm; invólucro globoso, 9-12 × 15-20 mm; brácteas involucrais 3-4-seriadas, ca. $35,4-8 \times 2-4,5 \mathrm{~mm}$, ovadas ou oblongas a ovallanceoladas ou elípticas, ápice agudo ou obtuso a arredondado, margem inteira, ciliada; receptáculo convexo, páleas conduplicadas, $8 \times 3 \mathrm{~mm}$, glabras, ápice truncado a obtuso. Flores do raio neutras, amarelas, corola liguliforme, tubo glabro, limbo 5-7 $\times 3 \mathrm{~mm}$, glabro. Cipsela obcônica, 3-angulosa, híspida; pápus aristado-coroniforme, $0,8 \mathrm{~mm}$. Flores do disco perfeitas, amarelas, corola tubulosa, tubo $5 \mathrm{~mm}$, glabro, lobos glabros; anteras de base sagitada, ápice ovado; ramos do estilete lineares, apêndices inconspícuos. Cipsela obcônica, 3,5 × 0,8-1 mm, serícea; pápus aristado-coroniforme, aristas 1,5-2 $\mathrm{mm}$, escamas $0,8 \mathrm{~mm}$.

Material examinado: BRASIL. Minas Gerais: Uberlândia, Reserva Ecológica do Panga, 22-V-1992, fl., fr., Araújo et al. 146 (HUFU, RB, SPF e UEC); 16-IV-1989, fl., fr., Mendes 104 (HUFU).

Material adicional examinado: BRASIL. MinAs GeRAIS: Araguari, Estrada para Pica-Pau Country Club: 16-IV-1989, fl., fr., Araújo s.n. (HUFU2066).

Viguiera robusta ocorre apenas no Brasil, nos estados do Amazonas, Tocantins, Bahia, Mato Grosso do Sul, Goiás, Minas Gerais, São Paulo, Paraná e no Distrito Federal. Esta espécie ocorre em cerrado sentido restrito na REP. $V$. robusta pode ser facilmente reconhecida pelas folhas ovadas, e os capítulos dispostos em corimbos longos e laxos.

\section{Agradecimentos}

O primeiro autor agradece à Capes pela bolsa de mestrado concedida, ao Programa de Pós-Graduação em Ecologia e Conservação de Recursos Naturais da Universidade Federal de Uberlândia pelo auxílio financeiro às viagens de visita a herbários do Brasil. À Dra. Rosana Romero, curadora do HUFU, por disponibilizar a coleção e estrutura do Herbário para a realização da dissertação, e aos curadores e funcionários dos herbários BHCB, CEN, ESA, IBGE, MBM, SP, SPF, UB e UEC durante as visitas feitas ao longo do ano de 2008. Os autores agradecem a Dra. Myrian Morato Duarte pelas ilustrações aqui apresentadas, e aos assessores pelas sugestões dadas ao manuscrito.

\section{Literatura citada}

Almeida, A.M., Fonseca, C.R., Prado, P.I., Almeida-Neto, M., Diniz, S., Kubota, U., Braun, M.R., Raimundo, R.L.G., Anjos, L.A., Mendonça, T.G, Futada, S.M. \& Lewinsohn, T.M. 2005. Diversidade e ocorrência de Asteraceae em cerrados de São Paulo. Biota Neotropica 5: http:// w w w. bi ot a n e otropica.org.br/v 5 n $2 /$ p t / abstract?article+BN00105022005 (acesso em 11.03.2009).

Almeida, G.S.S. 2008. Asteraceae Dumort. nos campos rupestres do Parque Estadual do Itacolomi, Minas Gerais, Brasil. Tese de doutorado, Universidade Federal de Viçosa, Viçosa.

Baker, J.G. 1873. Compositae I Vernoniaceae. In: C.F.P. Martius \& A.W. Eichler (eds.). Flora Brasiliensis, Frid. Fleischer, München, v. 6, pars 2, pp. 1-179.

Baker, J.G. 1876. Compositae II Eupatoriaceae. In: C.F.P. Martius \& A.W. Eichler (eds.). Flora Brasiliensis, Frid. Fleischer, München, v. 6, pars 2, pp. 181-374.

Baker, J.G. 1882. Compositae III Asteroideae, Inuloideae. In: C.F.P. Martius \& A.W. Eichler (eds.). Flora Brasiliensis, Frid. Fleischer, München. v. 6, pars 3, pp. $1-134$.

Baker, J.G. 1884. Compositae IV Helianthoideae, Mutisiaceae. In: C.F.P. Martius \& A.W. Eichler (eds.). Flora Brasiliensis, Frid. Fleischer, München, v. 6, pars 3, pp. 138-398.

Barroso, G.M. 1950. Considerações sobre o gênero Eupatorium. Arquivos do Jardim Botânico do Rio de Janeiro 10: 13-116.

Barroso, G.M. 1957. Flora do Itatiaia I. Compositae. Rodriguésia 32: 175-179.

Barroso, G.M. 1959. Flora da cidade do Rio de Janeiro (Compositae). Rodriguésia 21/22: 69-147.

Batalha, M.A. 2001. Florística, espectro biológico e padrões fenológicos do cerrado sensu lato no Parque Nacional de Emas (GO) e o componente herbáceo-subarbustivo da flora do cerrado sensu lato. Tese de doutorado, Universidade Estadual de Campinas, Campinas.

Borges, R.A.X. 2008. Asteraceae do Parque Estadual do Ibitipoca, Minas Gerais, Brasil: checklist e taxonomia de Astereae. Dissertação de mestrado, Instituto de Pesquisa Jardim Botânico do Rio de Janeiro, Rio de Janeiro.

Dubs, B. 1998. Prodromus Florae Matogrossensis. Série B. v. 3. The Botany of Mato Grosso. Beltrona-Verlag. Küsnacht. 
Esteves, R.L. 2001. O gênero Eupatorium s.l. (Compositae - Eupatorieae) no Estado de São Paulo, Brasil. Tese de doutorado, Universidade Estadual de Campinas, Campinas.

Funk, V.A., Susanna, A., Stuessy, T.F. \& Robinson, H. 2009. Classification of Compositae. In: V.A. Funk et al. (eds.) Systematics, Evolution, and Biogeography of Compositae. International Association for Plant Taxonomy, Vienna, pp.171-189.

Harley, R.M. \& Simmons, N.A. 1986. Florula of Mucugê, Chapada Diamantina, Bahia, Brazil. Royal Botanic Gardens, Kew.

Hattori, E.K.O. \& Nakajima, J.N. 2008. A família Asteraceae na Estação de Pesquisa e Desenvolvimento Ambiental Galheiro, Perdizes, Minas Gerais, Brasil. Rodriguésia 59: 687-749.

Hind, D.J.N. 1993. Notes on the Compositae of Bahia, Brazil: I. Kew Bulletin 48: 245-277.

Hind, D.J.N. 1995. Compositae. In: B.L. Stannard (ed.). Flora do Pico das Almas - Chapada Diamantina, Bahia, Brazil. Royal Botanic Gardens, Kew, pp. 175-278.

Hind, D.J.N. 2003. Flora of Grão-Mogol, Minas Gerais: Compositae (Asteraceae). Boletim de Botânica da Universidade de São Paulo 21: 179-234.

King, R.M. \& Robinson, H. 1987. The genera of Eupatorieae (Asteraceae). Monographs in Systematic Botany from the Missouri Botanical Garden. 22:1-581.

Lima, S.C. 1992. Mapeamento dos solos da bacia do Ribeirão Panga. Sociedade \& Natureza 4: 77-84.

Malme, N. 1932a. Die Compositae von der zweiten Regnellschen Reise. I. - Rio Grande do Sul. Arkiv for Botanik 24-A: 1-89.

Malme, N. 1932b. Die Compositae von der zweiten Regnellschen Reise. II. Mato Grosso. Arkiv for Botanik 24-A: 1-66.

Malme, N. 1933. Compositen Paranenses Dusenianae. Kongliga Svenska Vetenskapsakademiens Handlingar. 12: 1-122.

Moraes, M.D. 1997. A família Asteraceae na planície litorânea de Picinguaba, município de Ubatuba, São Paulo. Dissertação de mestrado, Universidade Estadual Paulista, Rio Claro.

Munhoz, C.B.R. \& Proença, C. 1998. Composição florística do município de Alto Paraíso de Goiás na Chapada dos Veadeiros. Boletim do Herbário Ezechias Heringer 3: 102-150.

Nakajima, J.N., Esteves, R.L. Gonçalves-Esteves, V., Magenta, M.A.G., Bianchini, R.S., Pruski, J.F. \& Hind, D.J.N. 2001. Flora Fanerogâmica da Reserva do Parque Estadual das Fontes do Ipiranga, São Paulo, Brasil: 159-Asteraceae. Hoehnea 28: 111-181.
Nakajima, J.N. \& Semir, J. 2001. Asteraceae do Parque Nacional da Serra da Canastra, Minas Gerais. Revista Brasileira de Botânica 24: 471-478.

Nakajima, J.N., Loeuille, B., Heiden, G., Dematteis, M., Hattori, E.K.O., Magenta, M.A.G., Ritter, M.R., Mondin, C.A., Roque, N., Ferreira, S.C., Teles, A.M., Borges, R.A.X., Monge, M., Bringel Jr., J.B.A., Oliveira, C.T., Soares, P.N., Almeida, G., Schneider, A., Sancho, G., Saavedra, M.M., Liro, R.M., Souza-Buturi, F.O., Pereira, A.C.M. \& Moraes, M.D. 2010. Asteraceae. In: R.C. Forzza et al. (eds.). Catálogo de Fungos e Plantas do Brasil. Jardim Botânico do Rio de Janeiro, Rio de Janeiro, v. 1, pp. 678-750.

Proença, C., Munhoz, C.B.R., Jorge, C.L. \& Nóbrega, M.G.G. 2001. Listagem e nível de proteção das espécies de fanerógamas do Distrito Federal, Brasil. In: T.B. Cavalcanti \& A.B. Ramos (eds.). Flora do Distrito Federal, Brasil, Embrapa Recursos Genéticos e Biotecnologia, Brasília, v. 1, pp. 89-359.

Ribeiro, J.F. \& Walter, B.M.T. 2008. As principais fitofisionomias do bioma Cerrado. In: S.M. Sano, S.P. Almeida \& J.F. Ribeiro (eds.). Cerrado: Ecologia e flora. EMBRAPA Cerrados, Brasília, v. 1, pp. 47-86.

Robinson, H. 1999. Generic and subtribal classification of American Vernonieae. Smithsonian Contributions do Botany 89: 1-116.

Rosa, R., Lima, S.C. \& Assunção, W.L. 1991. Abordagem preliminar das condições climáticas de Uberlândia (MG). Sociedade \& Natureza 3: 91-108.

Sasaki, D. \& Mello-Silva, R. 2008. Levantamento florístico no cerrado de Pedregulho, SP, Brasil. Acta Botanica Brasilica 22: 187-202.

Schiavini, I. \& Araújo, G.M. 1989. Considerações sobre a vegetação da Reserva Ecológica do Panga (Uberlândia). Sociedade \& Natureza 1: 61-66.

Schiavini, I. 1997. Environmental characterization and groups of species in gallery forests. In: J. ImanãEncinas \& C. Kleinn (eds.). Proceedings of the international symposium on assessment and monitoring of forests in tropical dry regions with special reference to gallery forests. Universidade de Brasília, Brasília, pp. 107-116.

Tannus, J.L.S. \& Assis, M.A. 2004. Composição de espécies vasculares de campo sujo e campo úmido em área de cerrado, Itirapina - SP, Brasil. Revista Brasileira de Botânica 27: 489-506.

Teles, A.M. 2008. Contribuição ao estudo taxonômico da tribo Astereae no Brasil e Senecioneae (Asteraceae) no estado de Minas Gerais. Tese de doutorado, Universidade Federal de Minas Gerais, Belo Horizonte. 